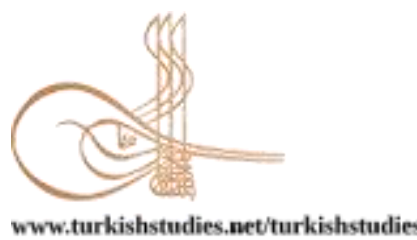

Turkish Studies

www.turkishstudies.net/turkishstudies

eISSN: $1308-2140$

BALAKAN

Sponsored by IBU

Research Article / Araștırma Makalesi

\title{
Kayıp Dergi: İstanbul Üniversitesi Edebiyat Fakültesi Sosyoloji Dergisi’nin 1983 Tarihli 23- 24. Sayısına Uygulanan Sansür*
}

\author{
Lost Journal: Practice of Censorship to the 1983 Date Issue 23-24 of the Journal of Sociology of \\ Istanbul University Faculty of Letters
}

\author{
Erkan Çav **
}

\begin{abstract}
Pressure on thought, blocking, censorship and destruction in the end, Turkey is one of the applications that are often experienced in the history of political and social. Censorship and pressure on thought had became ordinary and commonplace in the single-party period between 1923-1945 years that CHP's managing time. Especially during the coup periods activities of May 27, 1960, March 12, 1971, September 12, 1980 and February 28, 1997 doesn't look like past applications, each coup try to be better then before. In Turkey, 12 September 1980 military coup early years, in 1983, at the Istanbul University which is the center of sociology in this period, there has been an example of a censorship hard to believe. The last issue of the period, which was accepted as the second volume/series under the administration of Hilmi Ziya Ülken in 1960 in official records, was the 21-22. But now there was found that Journal of Sociology of the Istanbul University Faculty of Letters, has an issue that has been designed, but has not been published. This issue, which we call "Lost Journal" that was designed in 1983 as a 23-24 issue of Journal of Sociology of the Istanbul University Faculty of Letters, but the proof print was made and left/lost like this and/or it is estimated that all pages printed without the cover of the texts are censored and destroyed. When every ten years experience with coups or coup attempts in Turkey, one of the applications preferred by coup plotters is that suppression and censorship for prevent the spread of ideas, silence opposition and different approaches, prevent criticism and available existing ideas. Heretofore forgotten "Lost Journal" and its story; sheds light on a hidden event in the history of sociology, censorship and thought.
\end{abstract}

Structured Abstract: Istanbul University Department of Sociology is established for the second time in 1941 after the 1933 University Reform. In the same year, Journal of Sociology, whose first issue was published in 1917, starts its publication life again as a second volume. Journal of Sociology published in 1983 in memory of Hilmi Ziya Ülken who managing this process and publishing. But, Journal was censored before distributed.

Lost Journal Case, is not a case of censorship that can be ignored, ordinary and forgotten. This case has distorted the history of thought and sociology in Turkey. It is a case that somehow affects the sociology traditions/schools in the country. It brought irreparable losses. It has dealt a heavy blow to the understanding of free and independent scientific production.

\footnotetext{
* Çalışmamızda yapılan görüşmeler için Kahramanmaraş Sütçü İmam Üniversitesi Sosyal ve Beşeri Bilimler Etik Kurulu'ndan 06.10.2020 tarih ve 2020/28 sayılı karar ile Etik Kurul Onayı alınmıştır.

*** Dr., Bağımsız Araştırmacı

Dr., Independent Researcher

ORCID 0000-0002-8640-5505

caverkan@gmail.com

Cite as/ Atıf: Çav, E. (2021). Kayıp dergi: İstanbul Üniversitesi Edebiyat Fakültesi Sosyoloji Dergisi’nin 1983 tarihli 23-24. sayısına uygulanan sansür. Turkish Studies, 16(1), 103-149. https://dx.doi.org/10.7827/TurkishStudies.47218

Received/Geliş: 28 October/Ekim 2020

Checked by plagiarism software

Accepted/Kabul: 20 Şubat/February 2021

Published/Yayın: 25 Şubat/February 2021

CC BY-NC 4.0
} 
This censorship will always be the embarrassment of those who do it. Turkey's academic history is always a black censor case will be remembered. An important shortcoming of the history of sociology in Turkey has disappeared with our article. Thus, the Lost Jorunal emerged, 38 years later this dark event was to some extent illuminated. The case was understood more clearly in detailed interviews with academicians who were aware of the journal. Academics were adversely affected by this censorship.

Censorship on the date when made, Turkey is managing by the September 12 Coup. Bringing new and different views in this environment, Lost Journal could harm the Department, the University and its administrators. Lost Jorunal has been censored by the oppressive power that emerged in dark times such as the coup. Lost Jorunal Case has been one of the embodied practices of censorship with numerous reasons.

The academicians interviewed agreed that this case was a "dark" case that must be clarified on behalf of the Department of Sociology of the Istanbul University Faculty of Letters.

10 of the 15 articles in Lost Journal have been published definitively. The text of Cahit Tanyol's presentation in Madrid in 1967 and Ümit Meriç's article have not been published. There is no definite conclusion about the writings of Tayyib Gökbilgin, İbrahim Yasa and Adil Çağlar. However, regarding the status of the publishing process of other published 10 articles has been damaging to the history of sociology and thought in Turkey in the end.

Cahit Tanyol's article titled "Le fondement social du droit de l'Islâm" that namely "The Social Basis of the Law of Islam" and Ümit Meriç's article that is 120-page and has 1875 books, 81 periodicals and 4 encyclopedias, "A Bibliography Essay for Islamic Sociology" titled article was not published. These articles are the work of Sociology of Islam in Turkey, are remarkable text in different formats that may affect this area for new perspectives in years.

These two articles have not been published is a loss for the accumulation of thought and sociology in Turkey. These articles could have offer a positive contribution to the religion-secularism voltage which is one of Turkey's problems. If it was published the Lost Journal could give the opportunity to develop an academic backlog that balances conflicts positively on religion-secularism conflict in Turkey. Likewise, if these articles could meet with the academy, the world of thought and the society, with the richness of thought and discussion environment based on concrete sources, another coup could have survived the difficult years of the 28 February 1997 Coup without more loss.

Similarly, Mehmet Yalvaç's article that has important information about the history of Istanbul University Department of Sociology, was published two years late. But more importantly, this article was published in another journal, not in the journal of the section where it describes its history, so this situation delayed its intellectual contribution.

If Lost Journal had met with academia, thought and society in 1983 as a university publication, it would be an important achievement for the intellectual world of country. Censorship has destroyed this possibility.

The Lost Journal Case is a reflection of the practices of oppressive administrations, especially during the coup period, in the Academy. The institutions and their administrators with the oppressive mindset have made interventions preventing thought and intellectual accumulation in various periods and destroyed thought.

This censorship case can not be understood only with persons. This case can be understood better and complete if the academic mentality and system of this period are considered together. The "spirit of the era" was oppressive and censoring.

Similar cases were experienced in various forms in many public institutions, different universities, non-governmental organizations, even private companies and some structures of the society in the same years. This situation is a bad/negative and unacceptable experience. The transformation of this bad/negative experience into good/positive is only possible with a mentality transformation.

Keywords: Sociology, Censorship, Journal of Sociology of Istanbul University Faculty of Letters, Istanbul University Faculty of Letters Department of Sociology, Istanbul University, September 121980 Coup. 
Öz: Düşünceye baskı, engelleme, sansür ve nihayetinde yok etme, Türkiye siyasi ve sosyal tarihinde sıklıkla yaşanan uygulamalardan bir tanesidir. 1923-1945 yılları arasında CHP'nin yönettiği tek parti döneminde sansür ve düşünceye baskı sıradan ve olağan olmuştur. Bu deneyime dayanarak özellikle 27 Mayıs 1960, 12 Mart 1971, 12 Eylül 1980 ve 28 Şubat 1997 tarihli darbe dönemlerinde yapılanlar geçmiş uygulamaları aratmaz, her darbe diğerinden daha iyisini yapmak için adeta birbiriyle yarışır. Türkiye'de, 12 Eylül 1980 Darbesi'nin ilk yıllarında, 1983 yılında, bu dönemde sosyolojinin merkezi olan İstanbul Üniversitesi'nde, inanması güç bir sansür uygulamasının örneği yaşanmıştır. Resmi kayıtlarda 1960 tarihinde Hilmi Ziya Ülken yönetiminde ikinci cilt/seri/dizi olarak kabul edilen dönemin son sayısı olarak 1967-1968 y1lına ait 21-22. Sayı ile bitirilen İstanbul Üniversitesi Edebiyat Fakültesi Sosyoloji Dergisi'nin; tasarlanmış ve basılmış, fakat yayınlanmamış bir sayısı ortaya çıkmıştır. "Kayıp Dergi" olarak adlandırdığımız bu sayının; 1983 yılında "23-24. Sayı" şeklinde birleştirilmiş bir sayı olarak tasarlandığı, ancak prova baskının yapılarak bu şekilde bırakıldığı/kaybedildiği ve/veya sadece metinlere ait kapakları takılmadan basılmış tüm sayfaların sansüre uğrayarak yok edildiği tahmin edilmektedir. Her on yllda bir darbelerle veya darbe girişimleriyle karşılaşan Türkiye'de, darbecilerin tercih ettiği uygulamalardan bir tanesi muhalefeti ve farklı yaklaşımları susturmak, düşüncelerin yayılmasını engellemek, eleştiriyi önlemek ve mevcut fikirleri etkisiz kılmak için düşünceyi baskılamak ve sansürlemektir. Bugüne değin unutulmuş olan "Kayıp Dergi” ve hikâyesi; Türkiye'nin sosyoloji, sansür ve düşünce tarihinin gizli kalmış bir olayına ışık tutar.

Anahtar Kelimeler: Sosyoloji, Sansür, İstanbul Üniversitesi Edebiyat Fakültesi Sosyoloji Dergisi, İstanbul Üniversitesi Edebiyat Fakültesi Sosyoloji Bölümü, İstanbul Üniversitesi, 12 Eylül 1980 Darbesi.

\section{Giriş}

Sansür karşısında yapılabilecek en kolay şey, onu sineye çekmektir. Sansürü uygulayan güç, engellenemeyeceğini bildiği için bu uygulamayı rahatlıkla yapar. Ancak tarihin, yapılmış ve yapılan bütün baskıları, engellemeleri, susturmaları, yok etmeleri, sansürleri bir şekilde açığa çıkarabilmek gibi bir özelliği vardır. Tarih, hiçbir sansürün tamamen gerçekleşmesine izin vermez. Düşünce, en nihayetinde kendisine bir yol bulur. ${ }^{1}$

İstanbul Üniversitesi Edebiyat Fakültesi Sosyoloji Bölümü'nün 1971-1982 tarihleri arasındaki başkanı Prof. Dr. Cahit Tanyol [1914-2020] döneminde, 1980-1981 yıllarında makaleleri toplanan ve Sayı 23-24 olarak tasarımı yapılan, ancak yeni Bölüm Başkanı Doç. Dr. Baykan Sezer döneminde basılabilen Sosyoloji Dergisi'nin sansürlendiği, yani örtüldüğü, silindiği, engellendiği, kamuoyuna aktarılmadığı, unutturulduğu, ortadan kaldırıldığ ve/veya yok edildiği açığa çıkmıştır. 1980-1981 yıllarına ait olarak hazırlanan dergi, 1983 tarihinde dizilmiş ve prova ve/veya iç baskısı yapılmış olmasına rağmen akademi, düşünce dünyası ve toplum ile paylaşılmamıştır.

Kayıp Dergi’nin kopya bir nüshasına, 1982-1993 yılları arasında İstanbul Üniversitesi Edebiyat Fakültesi Sosyoloji Bölümü Başkanı olan Prof. Dr. Baykan Sezer'in Türkiye Diyanet Vakfı İslâm Araştırmaları Merkezi'ne (İSÂM) bağışlanan kitapları arasında ulaşılmıştır.

Kayıp Dergi'nin, prova ve/veya bundan daha ötesi içinin basılıp ciltlenmeden sansürlenmesinin, yani baskılanmasının, örtülmesinin, engellenmesinin, susturulmasının, gizlenmesinin ve yayından kaldırılmasının sebeplerinin değerlendirilmesi, Türkiye düşünce ve sosyoloji tarihi ve birikimi açısından önemle ele alınması gereken bir konudur.

\section{“Kayıp Dergi”nin Hikâyesi}

Karar verici vasileri olarak Prof. Dr. Ertan Eğribel ve Doç. Dr. Ufuk Özcan, Prof. Dr. Baykan Sezer'in kitaplarını 2013 yılında İslâm Araştırmaları Merkezi'ne bağışlarlar. İSÂM, diğer bağış̧̧̧ılarının bağışlarına yaptığı gibi Prof. Dr. Baykan Sezer'in de kitaplarına bütün dikkatiyle sahip

\footnotetext{
${ }^{1}$ Sansür konusunda, özellikle Tanzimat’tan itibaren yaşanan karmaşık siyasi ve sosyal hayat dikkate alındığında hemen her dönem benzeri süreçler olmuştur. Bu bağlamda bir inceleme için bkz. Kayış ve Hürkan, 2012. Cumhuriyet tarihinde Atatürk, İnönü ve Menderes dönemlerindeki sansürlerin Bakanlar Kurulu belgeleri üzerinden karşılaştırmalı incelemesi için bkz. Yılmaz ve Doğaner, 2007.
} 
çıkarak araştırmacıların, akademisyenlerin ve düşünce hayatına katkı verenlerin istifadesine sunmuştur. Hocaları ve çalışma arkadaşları olan Prof. Dr. Ümit Meriç'in de önerisi ile İSÂM'a kitapları bağışlama kararı veren öğrencileri ve çalışma arkadaşları, böylece Prof. Dr. Baykan Sezer'in kütüphanesinin, vefatından sonra da Türkiye'deki düşünce hayatına hizmet etmesinin devamını sağlamış oldular.

Mart-Temmuz 2020 Koronavirüs salgınına bağlı tedbir ve Karantina günlerinde kapalı olan İSÂM Kütüphanesi'ne, ilk açıldığı günlerde 22 Temmuz 2020 tarihinde Prof. Dr. Ümit Meriç'in birlikte hazırlamakta olduğumuz Sosyolojik Düşünce Atlası kitabının çeşitli metinlerinin kaynakça bilgilerini tamamlamak ve hocanın bibliyografyasını daha eksiksiz hale getirmek için gittik. Bu araştırma esnasında, İstanbul Üniversitesi Edebiyat Fakültesi Sosyoloji Bölümü’nün Ziya Gökalp tarafından 1917 y1lında 1. Cildi/Sersisi/Dizisi, 1941 yılında Prof. Hilmi Ziya Ülken tarafından 2. Cildi/Serisi/Dizisi² ve 1989 yılında Doç. Dr. Baykan Sezer tarafından 3. Cildi/Serisi/Dizisi çıkarılan Sosyoloji Dergisi'nin ciltleri arasında makalemizin konusu olan "Kayıp Dergi" ile karşılaştık. Mevcut son tasnif tasarımında 1917 tarihindeki dergi nüshaları olan 1-6 sayıları "Cilt 1", 1941³-1967 tarihleri arasındaki 1-22 sayılı dergi nüshaları "Cilt 2", 1989-2015 tarihleri arasındaki 1-31 sayıl1 dergi nüshaları "Cilt 3" olarak başlangıcındaki ismiyle tanımlanmıştır. 2016' da itibaren Cilt 36 Sayı 1-2, 2017 Cilt 37 Sayı 1-2, 2018 Cilt 38 Sayı 1-2, 2019 Cilt 39 Say1 1-2 ve 2020 Cilt 40 Sayı 1-2 şekilde bir cilt numarası ve sayı verme ile düzenlenmiş tasnif ve tanımlama yapılmaya başlanmıştır. ${ }^{4}$ Keşfettiğimiz "Kayıp Dergi", bu tasnif sistemine göre "Cilt 2" (Seri 2/Dizi 2) içerisinde yer alması gereken 1980-1981 tarihine işaretlenen ve fakat 1983 tarihinde basılan, 1967-1968 tarihli "Sayı 2122"nin devamı olarak "Sayı 23-24" olarak hazırlanmış olan Sosyoloji Dergisi nüshasıdır [Ek 1]. Mevcut siyah renkli olarak ciltlenmiş nüshanın "Sosyoloji Dergisi" yazan saman kağıdı İç Kapak Sayfası vardır [Ek 1]. Sosyoloji Dergisi 23-24. Sayısı olan Kayıp Dergi'nin ciltlenmiş nüshasının dış kapağında herhangi bir ibare, işaret veya başlık bulunmamaktadır. Derginin Kurucusu "Ord. Prof. Hilmi Ziya Ülken” [Ek 3], Basım Yeri "Edebiyat Fakültesi Matbaası" [Ek 2, Ek 3], Yayın Kurulu "Prof. Dr. Cahit Tanyol, Doç. Dr. Baykan Sezer, Doç. Dr. Haluk Yavuzer" [Ek 4] olarak geçer. Kayıp Dergi'nin İçindekiler sayfasından [Ek 6] önce Hilmi Ziya Ülken'in fotoğrafının bulunduğu "ithaf" sayfası [Ek 5] vardır. Kayıp Dergi, önceki sayıların ebatlarında, orta boy, 29 forma, 468 [numarasız kısımlarla birlikte 476] sayfadır. Bu sayfa sayısı ile Kayıp Dergi, 1917 yılında basılan 6 dergi ve 1941-1967 yılları arasında basılan 15 dergi [4-5, 10-11, 13-14, 17-18, 19-20 ve 21-22 sayıları tek seferde yayınlanmıştır] ile 1917 yılından itibaren gelen tüm Sosyoloji Dergisi sayıları-ciltleri içinde tek seferde basılmış ikinci en yüksek sayfa sayısına sahip dergi nüshası olur. İlki, 552 sayfa ile 1947 yılında basılan Sosyoloji Dergisi'nin birleştirilmiş 4-5 numaralı nüshasıdır. 1989'dan itibaren basılan 21 sayıdan sonra ise ancak dijital yayına da geçildiği dönemde 2011 yılındaki 3. Cilt 22. Sayı ile yine bu sayfa sayısı aşılacaktır. Böylece, Kayıp Dergi, kendisinden önceki sayı 4-5'ten sonraki 11 ve kendisinden sonraki 21 basılmış dergi nüshası içinde en yüksek sayfalı nüsha olur. Kayıp Dergi, 1941 yılından itibaren başlayan tarih ve sayı siralaması ile "GNL.DERGİ D00591" [Ek 1]

\footnotetext{
227 Mayıs 1960 Darbesi sonrasında Darbe Rejimi’nin 147 Öğretim Üyesini Üniversitelerden tasfiye ettiği süreçte Bölüm'den ayrılmak zorunda bırakılan Hilmi Ziya Ülken sonrasında Sosyoloji Dergisi'ni 1961-1968 yılları arasında Yayın Kurulu olarak Nurettin Şazi Kösemihal, Cahit Tanyol ve Hamit İnandık yönetir.

${ }^{3} 1941$ yıl1, aynı zamanda, 1933 Üniversite Reformu sonucu kapatılan Darülfünun yerine kurulan İstanbul Üniversitesi’nde Sosyoloji Kürsüsü’nün yeniden açılabildiği yıldır: “1933 Üniversite Reformu'yla, eskiden Felsefe bölümüne bağlı ders mahiyetindeki İçtimâiyat'ın (Sosyoloji) müstakil bir bölüm olması öngörüldü, fakat Edebiyat Fakültesi kadrosunda müstakil bir sosyoloji kürsüsü bulunmadığı için, 1936-1940 arasında sosyoloji kürsüsüz ve çeşitli zorluklarla sürdürüldü. Sosyoloji Hasan Ali Yücel'in desteği ve Hilmi Ziya Ülken'in gayretleriyle ancak 1941'de yeniden kürsü haline geldi” (İstanbul Üniversitesi Edebiyat Fakültesi Sosyoloji Bölümü Tarihçesi, https://sosyolojiedebiyat.istanbul.edu.tr/tr/content/hakkinda/bolum-tarihi). Bu bağlamda bakıldığında, İstanbul Üniversitesi Edebiyat Fakültesi Sosyoloji Bölümü'nün resmen 8 yıl (1933-1941), mekân tahsisi, kadronun tamamlanmas1 ve öğrenci alınması gibi süreçlere bakıldığında ise fiilen en az 10 yıl kapalı ve/veya pasif kaldığını söylemek mümkündür.

4 İstanbul Üniversitesi Edebiyat Fakültesi Sosyoloji Dergisi Dijital Arşivi (1917-2020) için bkz. https://dergipark.org.tr/tr/pub/iusosyoloji/archive.
} 
numaralandırması altında İslâm Araştırmaları Kütüphanesi'nde (İSÂM), İstanbul Üniversitesi Edebiyat Fakültesi Sosyoloji Dergisi arşivinin bir üyesi dergi cildi olarak raflarda yer almaktadır.

Siyah renkli bir kapakla ciltlenen "Kayıp Dergi”, 2003-2004 Yüksek Lisans dönemimizde “Türk Düşünce Dünyasında Cahit Tanyol" ve sonrasında 2004-2011 yılları arasındaki araştırmamızda derinleştirerek ortaya koyduğumuz Dramın Aydını Cahit Tanyol (2011) başlıklı kitap çalışmamız süresince İstanbul Üniversitesi'nin çeşitli kütüphanelerinde, Devlet Kütüphanesi’nde ve Ankara Millî Kütüphane'de ve diğer akademisyen ve fikir insanı kişilerin şahsi kütüphanelerinde incelemelerimizi yaparken karşılaşmadığımız, bilgisine sahip olmadığımız ve ilk defa 22 Temmuz 2020 'de İSÂM'da gördüğümüz ve keşfettiğimiz bir dergi cildi oldu. Cahit Tanyol'un [1914-2020] 90 y1lı ve 1400 maddeyi aşan Bibliyografyasını hazırlarken oluşturduğumuz ve diğer incelemelerimizdeki bibliyografyalarla yaptığımız karşılaştırmalarda da bu dergiye dair herhangi bir bilgiyi kayıt altına almadığımızı gördük. Dergiyi, diğer kütüphanelerin kataloglarında tarattık, ulaşamadık. Sosyoloji Dergisi'nin, 1917'den bugüne tüm arşivini dijital hale getiren İstanbul Üniversitesi Edebiyat Fakültesi Sosyoloji Bölümü'nün web sitesinde ve derginin arşivinde, Kayıp Dergi cildine dair hiçbir iz, işaret veya bilgi bulamadık. Herhangi bir sosyal bilim kitabında bu Kayıp Dergi hakkında hiçbir değerlendirmeye rastlamadık. 2007 yılında tamamlanmış "Türkiye'de Sosyolojinin Gelişiminde Dergilerin Rolü ve Önemi: İstanbul Üniversitesi Sosyoloji Dergisi" başlıklı İstanbul Üniversitesi Edebiyat Fakültesi Sosyoloji Dergisi'ni inceleyen doktora tezinde ve Sosyoloji Dergisi'ni kapsamlı olarak değerlendiren bir makalede de Kayıp Dergi üzerine herhangi bir bilgi yoktur (Ercan, 2007, 2013; Gürhan ve Yücedağ, 2020). Dolayısıyla, yapılan taramalar sonucunda Kayıp Dergi hakkında hiçbir yerde herhangi bir bilgi bulunamamıştır. Bunun üzerine Kayıp Dergi'nin hazırlanmasında yer alan veya dergide yazıları bulunan bugün sosyolojide akademisyenlik hayatına devam veya emekli olmuş konuyu bilebilecek dönemin Sosyoloji Bölümü öğretim üyelerine, Kayıp Dergi'de adı geçen bir Yayın Kurulu üyesine ve bir makalenin hazırlanmasında katkısı olan İstanbul Üniversitesi Sosyoloji Bölümü mezunu bir kişiye ulaştık. Bu makale, büyük ihtimalle Baykan Sezer tarafindan ciltlettirildiği anlaşılan keşfettiğimiz mevcut nüsha üzerine yaptığımız araştırma ve görüşmelerle elde ettiğimiz bilgiler ile çalışmamızın Ekler kısmında verdiğimiz Kayıp Dergi'nin ilgili basılmış hâlinin görselleriyle birlikte yaptığımız değerlendirmelerden oluşur.

\section{Kayıp Dergi'deki Makaleler/Yazılar}

Kayıp Dergi'deki makalelerin/yazıların listesi şöyledir:

1. Prof. Dr. Cahit Tanyol, "Hilmi Ziya Ülken'in Kişiliği ve Düşünce Dünyası”, s. 1-4 [Ek 7].

2. Prof. Dr. Cahit Tanyol, “Atatürk Devrimleri ve Hoca Kadri Efendi”, s. 5-50 [Ek 8].

3. Prof. Dr. Tayyib Gökbilgin, "Macaristan'daki Türk İdaresi ile İlgili Bazı Kaynaklar”, s. 51-60 [Ek 9].

4. Prof. Dr. İbrahim Yasa, "Tradition of Mutual Aid in Turkish Village", s. 61-80 [Ek 10].

5. Pertev Naili Boratav, "Mudurnu Türküleri", s. 81-124 [Ek 11].

6. Prof. Dr. Cahit Tanyol, "Le fondement social du droit de l'Islam", s. 125-136 [Ek 12].

7. Dr. Ümit Meriç, "İslâm Sosyolojisi İçin Bir Bibliyografya Denemesi", s. 137-258 [Ek 13].

8. Dr. Mahmut Arslan, "Step İmparatorlularında Ekonomik ve Sosyal Yapı”, s. 259-276 [Ek 15].

9. Doç. Dr. Fügen Berkay, "Genel Boyutları İçinde Yurtdışına İşgücü Göçü Olayı ve Bazı Sorunlar", s. 277-284 [Ek 16].

10. Doç. Dr. Baykan Sezer, "Yurdumuzda Sosyoloji", s. 285-328 [Ek 17].

11. Ziya Gökalp, "İlm-i İçtimâ' Dersleri”, Haz. Bedri Mermut[lu], s. 329-376 [Ek 18]. 
12. Dr. Mehmet Yalvaç, "İstanbul Üniversitesi Edebiyat Fakültesinde Sosyoloji Eğitiminin Tarihçesi (1912-1982)", s. 377-421 [Ek 19].

13. Dr. Tuğrul Tanyol, "Toplumsal-Kültürel Yapı ve Kişilik Kuramlarına Genel Bir Yaklaşım", s. 423-447 [Ek 20].

14. Prof. Dr. Kenneth Denbigh, "İlmi Metod: Düzen mi, Hürriyet mi?”, Çev. Dr. Ümit Meriç, s. 449-465 [Ek 21].

15. Dr. Adil Çağlar, "Kürsümüze Yapılan Doktora Tezleri”, s. 467-468 [Ek 22]. çıkar:

$\mathrm{Bu}$ makalelerin/yazıların içerikleri ve yayın durumları incelendiğinde şu sonuçlar ortaya

Kayıp Dergi'nin “Hilmi Ziya Ülken'in Kişiliği ve Düşünce Dünyası” başlıklı ilk yazısı, Prof. Dr. Cahit Tanyol'un (2006: XXIV-VI) Hilmi Ziya Ülken hakkında onun asistanı olarak fikirlerini ve yaklaşımlarını Ziya Gökalp ve Prens Sabahattin ile karşılaştırmalı olarak ele aldığı kısa ve özlü değerlendirmesidir. 1983 yılından sonra ancak 2006 yılında tekrar yayınlanabilen bu yazı, 23 yıl gecikmeli olarak topluma ulaşmıştır.

Prof. Dr. Cahit Tanyol (2003), "Atatürk Devrimleri ve Hoca Kadri Efendi” başlıklı ikinci makaleyi, 2003 yılında yayınlayacağı Hoca Kadri Efendi'nin Parlamentosu kitabı ile genişleterek 20 y1l sonra ancak bastırabilecektir.

Kayıp Dergi'nin üçüncü makalesi olan Prof. Dr. Tayyib Gökbilgin'e ait “Macaristan'daki Türk İdaresi ile İlgili Bazı Kaynaklar" başlıklı yazı, bugün, Gökbilgin adına açılmış olan web sitesinde yer alan bibliyografyada gösterilir. ${ }^{5}$ Dolayısıyla, Gökbilgin'in bu makalesinin IÜEF Sosyoloji Dergisi'nde basıldığ 1 kabul edilmiştir. Gökbilgin'in bibliyografyasında aynı isimli bir başka eser dikkati çekmemektedir. Dolayısıyla, bu makalenin başka bir isimle yeni basımı olmadıysa, mevcut durum Gökbilgin'in orijinal bir çalışmasının akademi, düşünce dünyası ve toplum ile buluşmadığı, yani basımının gerçekleşmediğidir.

Kayıp Dergi'deki dördüncü makale olan Prof. Dr. İbrahim Yasa'nın makalesi “Tradition of Mutual Aid in Turkish Village" ("Türk Köyünde Karşılıklı Yardımlaşma Geleneği”) başlığını taşıyor. Yaptığımız kütüphane ve katalog taramalarında bu makalenin aynı isimle daha sonra basıldığına rastlamadık. Prof. Dr. İbrahim Yasa'ya Armağan (1983) kitabının içinde bu isimle bir yazı veya bu çalışmay atıf yapan bir bilgi de bulunmamaktadır. Bu durumda, bu makalenin de orijinal olarak büyük ihtimalle "kayıp" durumunda olduğu ve basılmadığı yargısına varmak mümkündür.

Kayıp Dergi'nin beşinci makalesi, araştırmamızda daha önce başka bir kitap veya dergide yayımlanmayan, Hilmi Ziya Ülken'e ithaf edilen Kayıp Dergi'de ilk kez yayımlanmak üzere basımının planlandığı görülen Pertev Naili Boratav'ın “Mudurnu Türküleri” isimli derlemesidir. 44 sayfalık bu makale, hocası Hilmi Ziya Ülken'in yönlendirmesi ile Boratav'ın başladığı ve yaptığı ilk Halk Edebiyatı derlemelerinden oluşur.

"Hilmi Ziya Hocanın anısına armağan edilecek kitaba, eski bir öğrencisinin en yerinde katkısı, onun teşvikiyle ve rehberliğiyle giriştiği ilk derlemelerinin yayımlanması olur diye düşündüm. Aradan 52 y1l [1926-27»1983] gibi uzun bir süre geçtiği halde, bu metinleri bir arada yayımlama firsatı düşmedi. Bugün 'Mudurnu Türküleri' üzerine şu küçük incelemeyi Hocamın anısında adamak bana, bir çırağın ustasına olan, eski, çok eski bir borcunu ödemesinden gelen duyguya benzer bir mutluluk tattıracaktır" [Kayıp Dergi, s. 81-82]. ${ }^{6}$

\footnotetext{
5 Web sitesi için bkz. http://tayyibgokbilgin.info/turk-macar-yakinligi/. Aynı sitede verilen Gökbilgin'in tam bibliyografyasında bu metnin dizildiği ve baskıda olduğu bilgisi de verilir.

${ }^{6}$ Pertev Naili Boratav, halk edebiyatı araştırmalarına giden süreçte İstanbul Lisesi’ndeki hocası Hilmi Ziya Ülken'in etkisini şöyle anlatır: "1926-1927 ders yılı. İstanbul Lisesi'nin son sinıf edebiyat bölümünde okuyorum. Sosyoloji öğretmenimiz Hilmi Ziya, derslerinde, sırası düştükçe bize XIX. yüzyıl Avrupa ülkelerinde ulusal kültür hareketlerinden söz açıyor; oralarda halkın sözlü edebiyat gelenekleri üzerinde araştırmalara aydınların neden önem verdiklerini, bu alanda
} 
Boratav (1982: 378-417), bu derlemeyi aynı zamanda 1982 yılında, Kayıp Dergi'den önce basılan Folklor ve Edebiyat II kitabına alarak herhangi bir gecikmeye kalmadan yayınlanmasını sağlar. ${ }^{7}$ Aynı yazıyı Boratav (1993), 1993 yılında çıkan Toplumbilim dergisinin 2. sayısında da yayınlar. Böylece, bu makale, 1982 tarihli Edebiyat ve Folklor II kitabında aynı şekilde yer aldığı için içeriği yayınlanmış, toplumla paylaşılmış bir metin olarak her zaman ulaşılabilir olmuştur.

Kayıp Dergi'deki altıncı yazı Prof. Dr. Cahit Tanyol'un 23-28 Ekim 1967 tarihlerinde İspanya Madrid'te gerçekleşen XXI. Uluslararası Sosyoloji Kongresi'nde sunduğu "Le fondement social du droit de l'Islam" ("İslâm Hukukunun Sosyal Temeli") başlıklı metindir. Bu metin, daha sonra başka bir yerde basılmadığı için akademiye, düşünce dünyasına ve topluma ulaşmamış, dolayısıyla "kayıp" kalmış orijinal bir metindir. Şu ana kadar incelediğimiz yazılardan Cahit Tanyol'un "Hilmi Ziya Ülken'in Kişiliği ve Düşünce Dünyası" başlıklı yazısı 23 yıl sonra 2006 yılında, "Atatürk Devrimleri ve Hoca Kadri Efendi" başlıklı yazısı kitap olarak 20 yıl sonra 2003 y1lında ve "Le fondement social du droit de l'Islam" başlıklı 23-28 Ekim 1967 tarihli kongre konuşması ise hiçbir zaman basılmamıştır.

Kayıp Dergi' deki yedinci makale, Dr. Ümit Meriç'in 120 sayfadan oluşan “İslâm Sosyolojisi İçin Bir Bibliyografya Denemesi” başlıklı bibliyografik araştırmasıdır. Bu makalenin bir bölümü, 2 yıl sonra Temmuz-Ağustos 1985 tarihinde "İslâm Sosyolojisi Bibliyografyası Üzerine" başlığı ile İlim ve Sanat dergisinin 2. sayısının 97-100. sayfaları arasında ve 4 yıl sonra Mayıs-Haziran 1987 tarihinde "İslâmiyetle İlgili Seçme Yayınlar: Bir Bibliyografya Denemesi (İngilizce, Almanca, Fransızca)" başlığ ile İlim ve Sanat dergisinin 13. sayısının 81-87. sayfaları arasında yayınlanır (Meriç, 1985, Temmuz-Ağustos; Meriç \& Kot, 1987, Mayıs-Haziran). Ancak, bibliyografyanın bir bölümünü ortaya koyan bu kısa yayınlar yanında makalenin bütünü ele alındığında metnin halen orijinal olma özelliğini koruduğu ve 1980'lerin başında önemli bir İslâm Düşüncesi ve Sosyolojisi kaynakçası sunduğu görülür. Ümit Meriç'in "İslâm Sosyolojisi İçin Bir Bibliyografya Denemesi" başlıklı makalesi bütün olarak sonraki yıllarda, günümüzde değin 38 yıl boyunca başka hiçbir yerde yayınlanmamıştır.

Kayıp Dergi' deki sekizinci makale olan ve "Göçebelerde Sosyal ve Siyasal Kuruluş" başlıklı doktora tezinden hazırlanan Dr. Mahmut Arslan'ın "Step İmparatorlularında Ekonomik ve Sosyal Yapı" başlıklı yazısı, Step Imparatorluklarında Sosyal ve Siyasi Yapı başlığı ile 1 yıl sonra, 1984 yılında, İstanbul Üniversitesi Edebiyat Fakültesi Yayınları tarafindan kitap olarak basılır.

Kayıp Dergi'de yer alan dokuzuncu makale olan Doç. Dr. Fügen Berkay'ın “Genel Boyutları İçinde Yurtdışına İşgücü Göçü Olayı ve Bazı Sorunlar” başlıklı makalesi, 4 yıl sonra Malatya İnönü Üniversitesi Sosyal Bilimler Dergisi'nin 1987 yılında çıkan 1. sayısının 161-167. sayfaları arasında aynen basılmıştır. Bu çalışma, Berkay’ın 1988 yılında Malatya İsmet İnönü Üniversitesi tarafından yayınlanan Sosyal Değişme Açısından Yurt Dışına İş Gücü Göçü Olayı: İsviçre Örneği başlıklı kitabından oluşturulmuş bir yazıdır.

Kayıp Dergi’nin onuncu makalesi "Yurdumuzda Sosyoloji” başlıklı yazı ile Doç. Dr. Baykan Sezer'e aittir. 1983 tarihli basımda yazının dipnotunda şunlar dile getirilir: "Bu yazı, [Prof. Dr. Cahit

neler yaptıklarını anlatıyor; bu arada Finlilerin ulusal destanlarının dağınık parçalarını bir araya getirme yolunda bir ömür harcamış ve sonunda Kalevala'yı diriltmiş olan Lönnrot'un çalışmaları üzerinde uzun uzun duruyor. Hocam, halk edebiyatı sorunları üzerine anlattıklarına benim özel bir ilgi gösterdiğimin farkına varmış olacak ki, onunla başka vesilelerle konuşmalarımızda, sıra düştükçe, bu konulara dönüyor... Ders yılı sonunda Hocaya Üniversitenin Edebiyat Bölümünde okuma kararımı açıyorum. O yıllarda babam Mudurnu'da kaymakamdır; ben her yıl tatillerimi geçirmeye, Bolu ilinin sekiz yüz hanelik bu küçük kasabasına gidiyorum. Bunu öğrenen Hocam, bana o tatil için bir araştırma programı çiziyor: Mudurnu yerlileri ağzından türlü halk edebiyatı metinleri derleyeceğim. O tarihte henüz Latin alfabesi kabul edilmiş değildir. Derlemelerimin, dil özelliklerini yitirmeden yazılabilmesi için hocam, bir 'çeviri-yazı' kılavuzu veriyor elime. İşte, benim halk edebiyatı derlemelerimde ve araştırmalarımda ilk denemelerim böyle başlamıştır” (Kayıp Dergi: 81; Boratav, 1982: 378; Boratav, 1993). Ayrıca bkz. Ek 11.

${ }^{7}$ Kitabın yeni baskısı için bkz. Boratav, 2017. 
Tanyol yönetimindeki] Tecrübî Sosyoloji Sertifikası çerçevesinde sürdürülen aynı başlık altındaki derslerin 1980-1981 yılı ilk beş saati için hazırlanmış notların derlenmesinden oluşmaktadır." Bu ders notları, 6 yıl sonra, 1989 yılında “3. Dizi 1. Sayı” olarak tanımlanan Sosyoloji Dergisi”nin 1-96. sayfaları arasında, "Türk Sosyologları ve Eserleri I" başlığı ile tamamen aynı şekilde değiştirilmeden yayınlanır. ${ }^{8}$

Kayıp Dergi'nin onbirinci makalesi olan, Bedri Mermut[lu] tarafindan Latin harflerine çevrilen Ziya Gökalp'in "İlm-i İçtimâ Dersleri”, 12 yıl sonra, 1995 yılında “Ziya Gökalp'in Üniversite'de Okutmuş Olduğu İlm-i İçtimâ Dersleri” başlığı ile Türk Sosyoloji Dergisi'nin 1. Sayısının 119-164. sayfaları arasında yayınlanır.

Kayıp Dergi’nin onikinci makalesi olan Dr. Mehmet Yalvaç’ın, günümüz sosyoloji tarihi araştırmalarının vazgeçilmez kaynağı konumundaki "İstanbul Üniversitesi Edebiyat Fakültesinde Sosyoloji Eğitiminin Tarihçesi (1912-1982)" başlıklı makalesi, 2 yıl sonra, 1985 yılında, Kubbealtı Akademi Mecmuası'nın 1985'in Ocak ayındaki 1. sayısının 57-72. sayfaları ve Nisan ayındaki 2. sayısının 59-72. sayfaları arasında aynı şekilde içeriği değişmeden iki bölüm halinde yayınlanır.

Kayıp Dergi'nin onüçüncü makalesi olan Dr. Tuğrul Tanyol'un “Toplumsal-Kültürel Yapı ve Kişilik Kuramlarına Genel Bir Yaklaşım” başlıklı yazısı aynı isimle, 4 yıl sonra, 1987 yılında, Marmara Üniversitesi İ̈BF Dergisi'nin 1-2. Sayısının 575-598. sayfaları arasında yayınlanır.

Kayıp Dergi'nin ondördüncü yazısı olan Dr. Ümit Meriç’in "İlmi Metod: Düzen mi, Özgürlük mü?" başlığı ile Prof. Dr. Kenneth Denbigh’ten çevirdiği metin, 1 yıl sonra, 1984 yılında, IÜIF Sosyoloji Konferanslarl dergisinin 22. sayısının 25-42. sayfaları arasında yayınlanır.

Kayıp Dergi'nin onbeşinci yazısı olan Dr. Adil Çağlar'ın İstanbul Üniversitesi Edebiyat Fakültesi Sosyoloji Kürsüsü bünyesinde yapılan doktora tezlerini başlangıcından 1982 yılına değin listelediği "Kürsümüze Yapılan Doktora Tezleri” başlıklı yazısının ise başka bir yerde basıldığına rastlamadik.

\section{Kayıp Dergi Neden Sansüre Uğradı}

Derginin makaleleri incelendiğinde, Cahit Tanyol'un 1967 y1lında İspanya Madrid'teki XXI. Uluslararası Sosyoloji Kongresi'nde sunduğu 11 sayfalık "Le fondement social du droit de l'Islam" başlıklı konuşmasının ve Ümit Meriç’in 120 sayfalık "İslâm Sosyolojisi İçin Bir Bibliyografya Denemesi" başlıklı makalesinin bir bölümü hariç hiç yayınlanmadığından eminiz. Ancak, Tayyib Gökbilgin'in "Macaristan' daki Türk İdaresi ile İlgili Bazı Kaynaklar", İbrahim Yasa'nın "Tradition of Mutual Aid in Turkish Village" ve Adil Çağlar'ın "Kürsümüze Yapılan Doktora Tezleri” başlıklı yazılarının yaptığımız tüm araştırmalarda yayınlanmadığını görmemize rağmen, her durumda düşük bir oranla dahi olsa yayınlanmış olma ihtimallerinin olduğunu da düşünüyoruz. Bu 5 makale dışındaki tüm makalelerin 1 ile 23 yıl arasında yayınlandıkları, ancak bu şekilde akademiye, düşünce dünyasına ve topluma ulaştıkları görülür. Makale olarak yayınlanan ve yayın durumu kesin olmayan toplam 13 makale ile ilgili yapılan tek tek değerlendirmelerde görüldüğü üzere, bu makalelerin 12 Eylül 1980 Darbesi’nin getirdiği Darbe Rejimi koşullarıyla ve/veya Yükseköğretim Kurumu (YÖK)/Üniversite/Fakülte/Bölüm yönetimi ile görünürde çatışma yaşamasına sebep olabilecek özelliklerinin olmadığı anlaşılmaktadır. Başka bir ifadeyle, bu makalelerde, Bölüm, Dekanlık, Üniversite Yönetimi, YÖK ve/veya Darbe Rejimi'nin sansür uygulamasına sebebiyet verebilecek bir unsura kendi incelememizde rastlayamadık. Bunun tek istisnası Mehmet Yalvaç'ın makalesi ile ilgili olarak Fügen Berkay’ın dile getirdiği iddiadır. Bu iddiayı aşağıda ele alacağız.

Akademik bir çalışmanın basımının 3 ay, 6 ay ertelenmesinin bile kritik öneme sahip olduğu zamanlar olabilir. Ön kabul olarak, ileriki yıllarda yayınlanan makalelerde böyle bir olgu olmadığını

\footnotetext{
${ }^{8}$ Görebildiğimiz tek farklılık makalenin ikinci paragrafının sonunda yer alan "Bunu umuyoruz" cümlesinin 1989 tarihli baskıda olmamasıdır.
} 
varsayalım, ancak buna rağmen 1983 yılında yayınlanmak yerine sonraki y1llarda yayınlanan her makalenin gecikme süreleri toplandığında on yılları bulan bir yekûn ortaya çıkar. Bir de buna hiç yayımlanmayan metinleri eklediğimizde, her durumda Kayıp Dergi'nin Türkiye sosyolojisi ve düşüncesi açısından entelektüel bir fakirleşme getirdiğini söylemek mümkün olur.

Araştırmamızdaki temel olgu, yapılan bu uygulamanın sebebini anlamak, şu sorunun cevabını bulmaktır: "Kayıp Dergi hangi sebeple sansürlenmiş, yani engellenmiş, örtülmüş, susturulmuş, kapatılmış ve hatta yok edilmiştir?" Bu dergi, onu engelleyenler tarafindan niçin onay alamadı, susturuldu, yok edildi ve buna yönelik çok yönlü bir sansür uygulaması yapıldı? Ne oldu, niçin oldu, nasıl oldu da bir zihniyet ve gizli bir el bunu yapmaya karar verdi? Sansürcülere göre bu derginin yayınlanması kime, neye, niçin ve nasıl zarar verebilirdi?

Kayıp Dergi'nin hangi sebeplerle sansüre uğradığını anlamak için, öncelikle bu yıllarda derginin hazırlık aşamasında yer alan, makalesi ile katkıda bulunan ve İstanbul Üniversitesi Edebiyat Fakültesi Sosyoloji Bölümü'nde görev yapmakta olan öğretim üyeleri ve asistanları ile konuştuk. Devamında diğer ilgili kişiler ile de görüşmeler yaptık. Bütün ihtimalleri çok boyutlu olarak ortaya koymaya yöneldik. 1983 yılında, derginin Yayın Kurulu üyesi olan Doç. Dr. Haluk Yavuzer, Sosyoloji Bölümü'nde görev yapan ve Kayıp Dergi'de yazısı olan Doç. Dr. Fügen Berkay, Dr. Ümit Meriç, Dr. Korkut Tuna, Dr. Mahmut Arslan ve Dr. Mehmet Yalvaç, Bölüm mezunu ancak öğretmenlik yapan Bedri Mermutlu ile Meriç'in makalesine katkı veren Bölüm mezunu Ahmet Kot olmak üzere toplam 8 kişi ile görüşerek Sosyoloji Dergisi'nin bu "Kayıp" sayısı hakkında dönemin şahitlerinden bulunabilecek tüm bilgileri toplamayı amaçladık ve "Kayıp Dergi Olayı"nı, sansürün sebepleri ve sansürcüleri ile birlikte çok yönlü olarak aydınlatmaya yöneldik.

\section{1.İhtimal-Sebep-Yaklaşım: Cahit Tanyol ve Ümit Meriç’in Makalelerinin Getirdiği "İslâmî Perspektif"}

İlk ve en güçlü ihtimal, görüşülen akademisyenlerin düşüncelerinden ortaya çıkan olgu, Cahit Tanyol'un ve Ümit Meriç'in makaleleri ile Kayıp Dergi'de öne çıan "İslâmî Kimlik" boyutunun kabul edilmemiş olmasından gelen bir sansür olduğudur. 1970'lerin ortalarından itibaren önce iç dünyasında, devamında düşünce dünyasında bir dönüşüm yaşayan, bu eksende İslâm'a ve İslâm Sosyolojisi'ne yönelen Ümit Meriç, akademik bilgi ve birikimini İslâm kaynakları ile zenginleştirmeye başlar. Dergideki makalesi, Ümit Meriç'in 1975 yılında tamamladığı "Cevdet Paşa'nın Cemiyet ve Devlet Görüşü” başlıklı doktora tezi sonrası yaşadığı bireysel-entelektüel dönüşümünün bir yansımasıdır. Kur'an'ı Kerim'den "Her ilim sahibinin üstünde daha âlim biri vardır" (Yusuf Suresi, 76) ayetini epigraf olarak kullanan [Ek 13] Meriç, içsel-manevî dönüşümünde kendisine rehber olan Muzaffer Ozak'a makalesinde ise şöyle teşekkür eder: “ 'Güneşten bir zerre, deryadan bir katre' olan bu çalışmamı, Pek Muhterem Muzaffer OZAK Beyefendiye hürmet ve şükran duygularımla takdim ediyorum" [Ek 14]. Ümit Meriç, hazırladığı "İslâm Sosyolojisi İçin Bir Bibliyografya Denemesi” makalesini bu bağlam ile sunar. Makale, İslâm üzerine çalışmış çoğunluğu yabancı olan yazarların ve yabancı dilde eser vermiş Türkiyeli yazarların kitaplarının bibliyografik derlemesinden oluşur. Akademik araştırmalar için başvuru kaynakçası niteliğinde olan makale, aynı zamanda İslâm düşüncesini genel hatlarıyla ortaya koyan ve her başlıkta çeşitli öneriler getiren rehber bir çalışma olma özelliği taşır. Bu makale, kitapların 19 başlık/bölüm altında tasnif edildiği özellikli bir bibliyografyadır. İngilizce, Fransızca ve Almanca eserlerden oluşan Bibliyografya çalışmasında, her kitabın ismi aynı zamanda Türkçe olarak da verilir. Her başlıktaki/bölümdeki eserler soyadına göre alfabetik olarak sıralanır. Toplamda 1875 kitap, 81 süreli yayın ve 4 ansiklopedi isminden oluşan bibliyografyanın bölüm başlıkları ve her bir bölümde bulunan kitap adedinin dağılımı şöyledir: I-A) Kur'an'1 Kerim Mealleri (9) ve I-B) Kur'an'1 Kerim Hakkında Eserler (67), II-A) Hazret-i Muhammed (S.A.V.) ile İlgili Eserler (66) ve II-B) Hadis Tercüme ve Tetkikleri (27), II-C) Eshab-1 Güzîn [Dergide "Eshab-1 Güzîn" olarak dizilmiş doğrusu "Ashab-1 Güzîn" olacak] (R.A.) ile İlgili Eserler (18), III- Ansiklopediler (4), IV- Bibliyografyalar (37), V- 
Süreli Yayınlar (81), VI- Tarih (205); VII- İslâm Dini (142), VIII- Siyasi Hayat (83), IX- Hukuk (89), X- İktisadi Hayat (72), XI- Sosyal Hayat (201), XII- Aile Hayatı ve Kadın (52), XIII- Tasavvuf (136), XIV- Sanat Hayatı (144), XV- Edebiyat (81), XVI- Düşünce Hayatı, İlim ve Felsefe Tarihi (89), XVII- Eğitim Hayatı (30), XVIII- Avrupa ve İslâm (82), XIX- Yirminci Asırda İslâm (245) [Bölüm Başlıkları Ek 14].

Ümit Meriç (2020, 7-9 Ekim, görüşme), Kayıp Dergi’ye yönelik sansürün en büyük sebebinin kendi makalesi olduğu düşüncesindedir. Buna delil olarak, makalenin girişinde Yusuf Suresi 76. ayeti aktardığı "Her ilim sahibinin üstünde daha âlim biri vardır" ifadesini ve " "Güneșten bir zerre, deryadan bir katre' olan bu çalışmamı, Pek Muhterem Muzaffer OZAK Beyefendiye hürmet ve şükran duygularımla takdim ediyorum" şeklindeki ithafinı görür. Bu ifadelerin Üniversite, Fakülte ve/veya düşük bir ihtimal dahi olsa Bölüm yönetimi tarafindan olumsuz görülmüş olduğu kanaatindedir. Ümit Meriç (2020, 7-9 Ekim, görüşme), yöneticilerin büyük bir skandal olacağı açık olan "Ayet ve ithaf yazıdan çıkarılsın" da diyemedikleri için, diğer makalelerle birlikte Kayıp Dergi'nin yayınlanmasına tümden engel olduklarını tahmin eder. Meriç, makalesi ve makalesinde paylaştığı düşünceler ile Türkiye'deki Batıl1, Batıcı ve Batı-merkezci sosyolojiye karşı dünyanın farklı ülkelerinden yüzlerce yazarın İngilizce, Fransızca ve Almanca eserleri ile İslâm düşüncesi ve sosyolojisi bibliyografyası verir ve yine bu yazarlardan Jean Sauvaget'in ifadesiyle İslâm'in yükseleceği iddiasını taşıyan bir düşünceyi aktarır, bir anlamda bu yaklaşımı savunmuş olur. ${ }^{9}$ Dolayısıyla böyle bir iddiayı mevcut resmî-merkez ideolojiye tam bağlı ve bağımlı akademik ve bürokratik zihniyetin kabul etmesini beklemek, hele de bunun 12 Eylül 1980 Darbesi koşullarında İstanbul Üniversitesi çatısı altında akademik bir kapsamda gündeme gelmesine izin verilmesini düşünmek, mümkün değildir. Makalenin tekrar düzenlenmesi yönünde ve/veya Kur'an'dan alıntılanan ayetin ve manevî şahsiyeti ile öne çıkan bir isme yapılan ithafın yeniden ele alınması için herhangi bir talebin gelmemesi ise, bu sürecin ne kadar hassas, keskin ve ani bir kararla ilerlediğinin işareti olabilir.

Korkut Tuna (2020, 7-8 Ekim, telefon görüşmesi), yaptığımız görüşmede "Olmadık bir yazı mı sıkışmış araya, derginin bir ayıbı olacak o yazı sebebiyle o dergi öyle basılmadı" diyerek bir yazıya işaret etmiş, ancak bunun hangi yazı olduğunu somutlaştıramamıştır.

Ümit Meriç'in makalesi yanında Cahit Tanyol'un "Le fondement social du droit de l'Islam" ("İslâm Hukukunun Sosyal Temeli") başlıklı "İslâm hukuku" üzerine olan makalesini de eklemek gerekir. Bu iki metin, Kayıp Dergi'nin sayfa sayısı olarak 1/4'ünden fazlası olduğu için oldukça

\footnotetext{
${ }^{9}$ Ümit Meriç’in (Kayıp Dergi, 1983: 139-140) Jean Sauvaget'den yaptığı alıntı şöyledir: “'̇slâmiyet çok geniş bir coğrafyayı kaplıyor. Asya ve Avrupa kıtalarının büyük bir kısmı Müslüman. Geçen yüzyıllarda Avrupa'nın da önemli bir kısmına yayılmıştı İslâmiyet. Günümüzde, aşılmış bir medeniyet biçimi olmaktan çok uzak olan bu din, her gün yeni katılımlarla, biraz daha zenginleşip, büyüyor. Demek İslâm âlemini tek ve yekpâre bir bütün kabul etmek doğru değil. Asırlardan beri Müslüman olmuş bölgeler var, daha yakın tarihte İslâmlaşmış bölgeler var, henüz İslâmlaşmakta olan bölgeler var. İslâm Doğu'da doğdu ve ağırlık merkezi hep Doğu'da kaldı. Doğu'yu dikkatle incelemeden İslâmiyet'i anlamak imkânsızdır. Müslüman İspanya en şaşaalı günlerini yaşarken yine de bütünüyle Doğulu idi. İtalyanlar ve İspanyollar, öteden beri, kendi ülkelerinin İslâmî geçmişini merak ediyorlar ve inceliyorlardı. Son bir yüzyıldan beri, Kuzey Afrika'yı inceleyen Fransızlar da onlara katıldı. Batı ile İslâm dünyası arasında siyaset, din ve kültür teması her zaman olduğu için, Batı da İslâm âleminin bir parçasıdır. İslâm'ın kendinden uzaklaşışı XIX. asırda Batı'nın baskısıyla başladı. Çağımızda İslâmiyetin durumunu anlayabilmek için, tarih, bu yüzden son derece gerekli. İslâm tarihçisi 'İslâm'ın Yeşil Hilâl'ini çevreleyen toprakların tarihini ihmâl edemeyeceği gibi, İslâmî olmayan bölgelerin tarihçisi de, İslâm tarihini bilmezlikten gelemez. Bugüne kadar sosyal ve iktisadî tarihe az yer ayrıldı. Dil zorlukları ve üniversitenin kendi içindeki duvarlar 'Oryantalistler' ile tarihçileri sanki iki ayrı tür beşeriyet varmış, ortak bir insanlık tarihi yokmuş gibi birbirinden ayırdı.” Bu alıntıdan sonra Ümit Meriç (Kayıp Dergi, 1983: 140), yaptığı bibliyografya çalışmasının sebebini de ortaya koyan şu değerlendirmeyi yapar: "Bu satırların da açıç̧a belirttiği gibi İslâmiyet, Avrupalı araştıııcıların öteden beri yoğun ilgisini çeken bir çalışma alanıdır. Dinî, siyâsî, ideolojik veya ilmî... pek çok sebebe bağlanabilecek olan bu dikkate, asrımızda yeni bir sebep daha eklendi: Bizzat kendileri din olarak İslâm'ı seçen bazı Batılı araştırıcılar, Avrupa dillerinde İslâmiyet'in çeşitli yönleriyle ilgili eserler kaleme almağa başladılar. Gittikçe zenginleşen İslâmî neşriyata, özellikle İngilizce yazan Doğulu Müslümanların yayınları da ilâve olunca, karşımıza Batı dilleriyle yazılmış eserlerden kurulu, muazzam bir 'İslâm Kütüphanesi' çıkmaktadır."
} 
dikkat çekmiş olmaları muhtemeldir. Derginin basılma çalışmalarını bilen, kendisinin makalesi de yayınlanmak için alınan Mehmet Yalvaç (2020, 7 Ekim, telefon görüşmesi), tam emin olmamakla birlikte içinin tamamen basıldığını ve ciltlenmeye hazır hale geldiğini söylediği Kayıp Dergi için dönemin İstanbul Üniversitesi Edebiyat Fakültesi Dekanı Prof. Dr. Sencer Tonguç'a gidilerek "Dergide irticaî yazı var" şeklinde ihbarlar yapıldığını, bu sebeple derginin iptal edilerek yayınlanmadığını, öğrendiğini aktarır. Fügen Berkay (2020, 7 Ekim, telefon görüşmesi) da, Ümit Meriç'in makalesinin "bahane" olarak kullanılmış olabileceğini düşünür. Fügen Berkay, Ümit Meriç ve Mehmet Yalvaç (2020, 7 Ekim, dörtlü telefon görüşmesi), Meriç'in makalesinin “irticâ̂” olarak damgalanmış olabileceği konusunda ittifak ederken, ortak görüşme esnasında yapılan tüm değerlendirmelere rağmen bu makalenin "irticâ̂" olduğunu kimin/kimlerin Dekanlığa "ihbar etmiş" olabileceği konusunda bir sonuca varamamışlardır. Nihayetinde, ulaştığımız bulgular, Cahit Tanyol'un "İslâm Hukukunun Sosyal Temeli" ve Ümit Meriç'in "İslâm Sosyolojisi İçin Bir Bibliyografya Denemesi” başlıklı makalelerinin getirdiği İslâmî entelektüel bakış ve çerçevenin, Darbe Rejimi koşullarında tehlike olarak algılanarak bu makalelerin "irticaî oldukları" bahanesiyle sansür için kullanılmış olmalarını, en yüksek ihtimal olarak ortaya koymaktadır.

\section{2.İhtimal-Sebep-Yaklaşım: Mehmet Yalvaç'ın Makalesi}

İstanbul Üniversitesi Edebiyat Fakültesi Sosyoloji Bölümü Başkanı Baykan Sezer’in, Kayıp Dergi'nin sansürlenmesindeki etkisi nedir? Bu soruyu, olumlu-olumsuz yönde kesin biçimde netleştirmek, Baykan Sezer vefat ettiği için mümkün değildir. Yapılacak bütün değerlendirmeler tahmin olarak kalacaktır. Bu konuda Fügen Berkay'ın (2020, 7 Ekim, telefon görüşmesi) iddiası şöyledir: Mehmet Yalvaç, "İstanbul Üniversitesi Edebiyat Fakültesinde Sosyoloji Eğitiminin Tarihçesi (1912-1982)" başlıklı makalesinde "Türkiye Sosyolojisi" isimli dersin yıllar boyunca Prof. Dr. Cahit Tanyol tarafından verildiğini resmi kayıtlara göre belgeleyerek, bu konuda "yeni bir sosyolojik yaklaşım” iddiası ortaya koymak isteyen Baykan Sezer’in önünü kesmiştir. Başka bir ifadeyle bu iddia, Baykan Sezer'in kendisinin sosyolojide "yeni bir yaklaşım" iddiasının önünde engel olarak gördügü için, aynı alanda kendisinden önce uzun yıllardır çeşitli çalışmalar yapan ve dersler veren hocası Prof. Dr. Cahit Tanyol'un akademik faaliyetlerini ayrıntılı biçimde ortaya koyan bir makalenin yayınlanmasını engellediğidir. Öte taraftan, "Sosyoloji Dergisi'nin yeni dizisini yayınlayalım" diyen Baykan Sezer' in bu talebini dönemin Bölüm Başkanı Cahit Tanyol kabul etmez, 1960 tarihinde başlayan cildin/serinin/dizinin devamını ister (Berkay, 2020, 7 Ekim, telefon görüşmesi). ${ }^{10}$ Dolayısıyla, dayandırdığı bu olgular ve durumlar sebebiyle Fügen Berkay $(2020,7$ Ekim, telefon görüşmesi), Kayıp Dergi'nin basımının ve yayımının engellenmesini Cahit Tanyol ile Baykan Sezer arasında yaşanan çatışmalara da bağlar. Mehmet Yalvaç (2020, 7 Ekim, telefon görüşmesi) da, daha geride bir ihtimal olmakla birlikte Bölüm içi çatışmaların derginin yayınlanmasını engellemiş ve bu şekilde Kayıp Dergi’nin basılmamış olabileceğini düşünür.

Fügen Berkay'ın söz konusu iddiasını değerlendirebilmek için, iddiasında dile getirdiği “Türkiye Sosyolojisi” yaklaşımının İstanbul Sosyoloji Geleneği'ndeki [İstanbul Ekolü'ndeki] yerine Cahit Tanyol perspektifinden bakmamız gerekir. Prof. Dr. Cahit Tanyol, ilk olarak 1963-1964 Eğitim Yılında "Türkiye'de Sosyoloji Akımları" dersini, devamında yönettiği Umumi Sosyoloji Sertifikası kapsamında 1969-1970 yılında "Türkiye Sosyolojisi" Seminer dersini ve nihayetinde 1974-1975 yılından itibaren "Türk Sosyologları ve Eserleri" dersini verir (Yalvaç, 1985, Ocak; 1985, Nisan) [Kayıp Dergi: 377-421]. Bu adımlarıyla Prof. Dr. Cahit Tanyol, İstanbul Üniversitesi Edebiyat Fakültesi Sosyoloji Bölümü’nün kuruluşundan itibaren baskın olan Batı Sosyolojisi merkezli gelişen anlayışın ve yaklaşımın, Doğu, Türkiye ve Anadolu merkezli olan bir sosyoloji anlayışına doğru yönelmesinin ve bunun kurumlaşmasının temellerini atar. ${ }^{11}$

${ }^{10}$ Baykan Sezer bu hedefine, Cahit Tanyol'un yaş haddinden emekliliğinden sonra devraldığı Bölüm Başkanlığ1 döneminde, 1989 yılında yeni sayısı yayınlanan Sosyoloji Dergisi'nin ismine “3. Dizi” adını vererek ulaşır.

${ }^{11}$ Bu sürecin kapsamlı değerlendirmesini 2011 yılında yayınlanan Dramın Aydını Cahit Tanyol başlıklı kitabımızda yaptık. İstanbul Üniversitesi Sosyoloji Bölümü'ndeki “Türkiye Sosyolojisi” anlayışının gelişimi, bu gelişimde Cahit Tanyol'un 
$\mathrm{Bu}$ süreçte Bölüm içinde farklı sosyoloji yaklaşımlarından kaynaklanan zorluklar yaşanmıştır. Bunlardan öne çıkan bir tanesi Umumi Sosyoloji Sertifikası sorumlusu Cahit Tanyol'un "Türkiye Sosyolojisi" ismiyle bir seminer dersinin açılması talebinin, Bölüm Başkanı ve Tecrübi Sosyoloji Kürsüsü sorumlusu Nurettin Şazi Kösemihal tarafından kesinlikle kabul edilmemesidir. Kösemihal'in Bölüm Başkanı olarak böyle bir dersin açılmasını kabul etmediğini İstanbul Üniversitesi Edebiyat Fakültesi Dekanlığı'na bildirmesi ve konuyla ilgili olarak Tanyol'un Dekanlığa açıklama yazısı yazması sonrasında, Sosyoloji Bölümü’nde yaşanan bu çatışmayı aşmak için Dekanlık tarafindan bir komisyon kurularak oradan gelecek raporla "Türkiye Sosyolojisi" isimli dersin açılıp açılmaması hakkında nihai kararın verilmesi uygulamasına gidilir. Dekanlık kararı ile kurulan komisyonda Bölüm Başkanı Prof. Dr. Nurettin Şazi Kösemihal, Kösemihal'in asistanları Dr. Muzaffer Sencer ve doktorant Oya Baydar Sencer, Umumi Sosyoloji Sertifikasi sorumlusu Prof. Dr.

rolü ve Kemal Tahir'in etkisi bağlamında isimlerin ve Geleneğin [Ekolün] "anlamlı ve doğu tanımlanması” üzerine 2011 yılında yaptığımız değerlendirmeden bazı kısımları bir kez daha hatırlatmak istiyoruz: "Tanyol'un, baştan beri var olan ancak Kemal Tahir ile yakın ilişkide olduğu 1960'larda yoğunlaşan ve yaygınlaşan yerli düşünce ve kaynaklara eğilen sosyoloji bakışıyla Osmanlı toplum yapısı bağlamında Türk toplum yapısına yaptığı vurguların ve ekonomik kalkınmaya indirgenerek de olsa sosyalizm çerçevesinde ele aldığı yaklaşımların, Doğu-Batı ilişkisine getirdiği açılımlar açısından dönem içerisinde gözden kaçırılamaz bir değeri vardır. Ancak bu değerde Kemal Tahir'in rolü İstanbul Sosyoloji Geleneği’nin kökleri ve kökenleri ile beslenmese ve ona aşılanmasa anlamsız kalırdı. Sosyoloji Bölümü düşüncesinde geleneğin yadsınarak ve 1960'tan itibaren Kemal Tahir'e yaslanarak ve onun üzerinden yeni bir kök ve köken arayışının benimsenmesi mümkün değildir. Osmanlı devlet ve toplum yapısını bugünün Türkiyesi için temel ve model alarak günümüz koşulları içinde yeniden yorumlama düşüncesi Tanyol'da Kemal Tahir'le birlikte başlamaz. [Baykan Sezer'in 'Belki de bir tepki olarak Kürsümüzde Kemal Tahir etkisi hocamız Cahit Tanyol ile başlamıștır' (Baykan Sezer'in Biyografisi ile İlgili Sorulara Verdiği Cevaplar, 2004) tespiti doğru, ama eksiktir]. Tanyol, 1940'lı yılların başında öğrenciyken ve Hilmi Ziya Ülken'in asistanıyken Osmanlıca metinleri derslerde ve seminerlerde okur ve okutur, aynı yıllarda Yahya Kemal'in Osmanlı ve Selçuklu merkezli bin yıllık tarih anlayışını okumalarıyla genişleten, felsefe formasyonu ve sosyoloji bilgisi almış bir birey olarak düşüncelerini ve sosyolog özelliklerini geliştirir. Bunun öncesinde 1939-1940 yıllarında çıkardığı Aramak edebiyat ve fikir dergisinde tarihten gelen birikimi 'Asya Tefekkürü' başlığında edebiyat ve tarih hassasiyeti içinde derginin yayın politikasına ve makalelerine yansıtması ve 1940'l1, 1950'li yıllardaki incelemeleriyle bunu genişletmesi, 1920'lerde Muallim Mektebi'nden hocası Türk tarihi ve medeniyeti üzerine çalışan ve bu alanda çeşitli eserler veren Arif Nihat Asya'nın düşünce dünyasını belirleyen temel kişilerden biri olması, 1960'lara değin yazdığı yüzlerce makalede bu görüşlerini derinleştirmiş olması, Tanyol'un düşünce dünyasındaki ve 1960'larda Bölüm'ün sosyoloji anlayışındaki dönüşümün temelini sadece Kemal Tahir'e bağlamayı geçersiz kılar. Tanyol'un birikimine Hilmi Ziya Ülken'in İslâm Düşüncesi üzerinden oluşturduğu kapsamlı Türk Düşüncesi külliyatı da eklendiğinde İstanbul Üniversitesi Sosyoloji Bölümü’nün Ziya Gökalp’ten itibaren başlayan geleneğinin içeriğine Osmanlı tarihinin merkeze oturması sadece Kemal Tahir üzerinden açıklanamaz. (...) Kemal Tahir bağlamında, ne onun düşüncelerini ve Bölüm'deki etkisini abartan, ne de azaltan, önemsizleştiren veya yok sayan bir yorumun geçerli olmadığını, bu bakışların dışında Kemal Tahir'in Türkiye'deki Çağdaş Düşünce'ye, kökenleri bu topraklarda güçlü biçimde var olan 'yerlilik' kanalından bağlandığını ve bu kanal üzerinden bunu yeniden açığa çıkaranlardan biri olarak Türkiye'deki düşünce dünyasında konumlandırılmasını benimsemek, daha dengeli bir yaklaşım olur. (...) Kişileri geleneğe dahil etmek yerine, geleneği kişilere dahil etmenin en büyük zararı düşünce akışını ve aktarımını sağlayan geleneğe olur. (...) Cahit Tanyol ve Baykan Sezer'i, ikisini birlikte içinde bulundukları İstanbul Sosyoloji Geleneği’nin bütünlüğü içinde birer sosyolog olarak değerlendirmek, bu merkezden düşünsel açılımlara ulaşmak gerekir. (...) İstanbul Sosyoloji Geleneği'nin dönüşümlerini, Kemal Tahir'in Türk sosyolojisindeki karşılığını, Cahit Tanyol’un Hilmi Ziya Ülken ile günümüz sosyolojisi arasındaki etkisini ve bağlantısını, Baykan Sezer'in Türk sosyolojisindeki konumunu, yöntem ve düşünce olarak yaygınlığını ve Kemal Tahir'le olan düşünsel ilişkisini ölçülü değerlendirmek, abartıya kaçmadan, aşırı öznellik vurgusu yapmadan, yerlilik geleneğinin bu topraklarda kendi medeniyetleri ve kültürleri olan toplumları ve devletleri kuran derin ve yerleşik köklerini göz ardı etmeden, kolaycı ilişkilendirmelerden ve klişe cümlelerden uzak durarak, her deneyimin kendi sınırları içindeki boyutlarını bilerek ve vurgulayarak, kısıtlayıcı ve yüzeyselleştirici genelleştirmelere başvurmadan, Türkiye'de bilgi, bilgikuramsal ve bilim yapma süreçlerinin epistemeyi oluşturan bütünsel ilişki ağlarını dikkate alarak incelemek ve yorumlamak gerekir. Aksi durumlarda yapılan yorumlar, düşünsel ilişkilendirmeleri eksiltmeye ve kapatmaya, ölçüsünü aşan değer atıflarını yapmaya, insani ve hocalık vasıfları ile bilim yapma ve uygulama arasındaki sınırları karıştırarak duygusal ve kişisel ilişkilere dayalı olarak yaklaşımları bireyselleştirmeye ve buna bağlı bir düşünme biçimine, Türkiye'deki Çağdaş Düşünce'yi ve açılımlarını bu kalıplarla zorlayarak daraltmaya ve sathileştirmeye, bunlarla beraber farkları, farklılıkları, özgünlükleri, ayrışıklıkları kategorileştirerek aynileştirmeye ve bütün bu düşünme uygulamalarındaki farklı kaymalara bağlı olarak anlam ve kavrayış yanlışlıklarına yol açar. Bu da sadece Darülfünun-İstanbul Üniversitesi ve İstanbul Sosyoloji Geleneği'ni değil, bu topraklardaki bütün bir duygu ve ifade, düşünme ve düşünce, yaşam ve varoluş geleneğinin köklerini, oluşumunu, tarihsel birikimini, derûniliğini, gücünü ve dinamiğini yadsımak olur” (Çav, 2011: 553563; "İstanbul Sosyoloji Geleneği ve Cahit Tanyol” başlıklı bölüm). 
Cahit Tanyol, Tanyol'un asistanı doktorant Fügen Berkay ve Komisyon'da tarafları dinleyerek nihai Raporu yazacak olan Prof. Dr. Mehmet Kaplan yer alır. Toplantı, 1968 yılının eğitim-öğretim yılı başlarında, Eylül-Kasım ayları arasında Kösemihal'in odasında gerçekleşir. Odaya getirilen dört köşe bir masa etrafında, kapı tarafında Prof. Dr. Cahit Tanyol, pencere tarafında Prof. Dr. Nurettin Şazi Kösemihal, Tanyol'un solu ve Kösemihal'in sağında yer alan masa kenarında Dr. Muzaffer Sencer, doktorant Fügen Berkay ve doktorant Oya Baydar Sencer, onların karşısında ise bütün masaya riyaset eden Prof. Dr. Mehmet Kaplan oturur. Toplantıda, Kösemihal ve Sencerler "Türkiye Sosyolojisi ne demektir? Sosyoloji evrensel bir bilimdir, Türkiye Sosyolojisi diyerek daraltılamaz. $\mathrm{Bu}$ isimle ders açılması evrensel sosyoloji anlayışına uymaz" şeklindeki temel argümanlarını savunurlar. Tanyol, Batı sosyolojisi, yani Avrupa-merkezci/Bat1-merkezli/Bat1-merkezci olan bu argümana karşı sosyolojinin yapıldığı toplum ve ülke ile olan bağının önemine vurgu yapan, tarih ve coğrafya ile ilişkisini ortaya koyan bir yerli/yerel sosyolojik yaklaşımla açmak istediği "Türkiye Sosyolojisi" dersini savunur. Kaplan, herkesi dinledikten sonra son sözü, "Senin görüşün nedir?" diye sorarak henüz asistanlıkta bir yılını doldurmuş olan Fügen Berkay'a verir. Berkay da "Bir bilim varsa ve bu da sosyal bilimse, sosyal yapıyı inceleyecekse ve burası da Türkiye ise 'Türkiye Sosyolojisi' dersi olmalıdır" diyerek cevap verir. Her iki tarafın da düşüncelerini açık biçimde ortaya koyduğu, Fakülte kararı ile yapılan ve hararetli geçen bu resmi toplantıyı Kaplan, Berkay'ın (2020, 10 Ekim, telefon görüşmesi) sözlerinden sonra kapatır. "Türkiye Sosyolojisi” dersi; Bölüm içinde ders üzerine yaşanan ayrışma, Kaplan'ın "dersin açılması yönünde görüş bildiren” olumlu raporunun belki henüz tamamlanmamış olması, Fakülte Kurulu'ndan onayın zamanında çıkmamış olması veya diğer bir ihtimal 1968 üniversite öğrenci olayları sebebiyle 1968-1969 Öğretim y1lında açılmaz. "Türkiye Sosyolojisi” dersi ancak, 1969-1970 Öğretim yılında resmen açılarak öğrenci alır. "Türkiye Sosyolojisi" isimli dersin açılması sürecinde yaşanan bu olay, İstanbul Üniversitesi Edebiyat Fakültesi Sosyoloji Bölümü'nün, yani İstanbul Sosyoloji Geleneği'nin [İstanbul Ekolü'nün] sosyoloji anlayışında "tarihi bir kırılma anına" işaret eder: Batı-merkezci/Batı-merkezli Batı Sosyolojisi anlayışının egemenliğine karşı Batı-dışı, yerli/yerel, yani Türkiye-merkezci/Türkiyemerkezli bir sosyoloji anlayışııın kendini ortaya koyması. Cahit Tanyol'un başını çektiği Yerli/Yerel Sosyoloji, özel adiyla "Türkiye Sosyolojisi", bu tarihten sonra İstanbul Sosyoloji Geleneği'nin/Ekolü'nün merkezî yaklaşımı olur. Bugün, gerek İstanbul Sosyoloji Geleneği kapsamında, gerekse Türkiye'de ondan etkilenen ve onu izleyen sosyoloji bölümlerinde bu yaklaşım temsilcilerini bulmuş, yaygınlaşarak Türkiye genelinde düşüncede ve uygulamada varlığını ortaya koymuştur.

“Türkiye Sosyolojisi” isimli dersin açılmaması ile 1994 yılında Prof. Dr. Ümit Meriç’in Bölüm Başkanlığı (1993-1996) döneminde Baykan Sezer ve bölüm üyelerinin ortak kararı ile İstanbul Üniversitesi Edebiyat Fakültesi'nin Fakülte Kurulu'na sunulan "Türkiye Sosyolojisi Anabilim Dalı" açılması önerisinin reddedilmesi süreci arasında benzerlik vardır. İstanbul Üniversitesi Edebiyat Fakültesi Sosyoloji Bölümü'nün teklif ettiği "Türkiye Sosyolojisi Anabilim Dalı" açılması önerisi, Fakülte Kurulu, Rektörlük veya Senato aşamalarından birinde "reddedilmiş", bu isimle yeni bir anabilim dalının açılması mümkün olmamıştır (12 Nisan 1994 tarihli not; Meriç, 1994). "Türkiye Sosyolojisi Anabilim Dalı" kurulması önerisi, İstanbul Üniversitesi Edebiyat Fakültesi Sosyoloji Bölümü’nün kimliğinin "yerli/yerel” özelliğinin sürekliliğini ortaya koyması bakımından önemlidir. Başından itibaren yaşanan çatışmalı durumuna rağmen Sosyoloji Bölümü "Türkiye Sosyolojisi" isimli dersi açmaya devam etmiştir.

“Türkiye Sosyolojisi” dersine gelen sürecin Cahit Tanyol'un fikri gelişim planındaki olguları ise şöyledir: Cahit Tanyol'un (1939, Nisan; 1940, Eylül), ilk sayısında "Biz; bu küçük mecmua içinde -iddiasız- kendimizi, bizden olanı aramağa çalışacağız" dediği ve "Aramak mecmuasının en büyük gayelerinden biri de Asya tefekkürünü, bu tefekkür içinde Türk medeniyetinin inkişaf tesirlerini mütalaa etmektir" şeklinde amacını tanımladığı Aramak dergisinde ortaya koyduğu 1940'lardaki 
Asya merkezli bakış açısı ${ }^{12}$ ve 1950 'lerde yaptığı ve Doğu-Batı ikiliğini ele aldığg ve bizim yerimizin Doğu'da olduğunu açıkça belirtiği çalışmaları; Tarih-i Cevdet'i yazan ve İslâm Hukuku'nun esaslarını ortaya koyan Mecelle'nin mimarı olan Osmanlı'nın Tanzimat dönemi büyük devlet adamı ve fikir insanı Ahmet Cevdet Paşa'yı (1822-1895) ve dört ciltlik Tarih-i Umumi'yi (Genel Dünya Tarihi) yazan Mizancı Murat'1 (1854-1917) Sosyolojinin Osmanl1-Türkiye çizgisindeki kurucu isimleri olarak işaret eden ve Osmanl1-Türkiye çizgisinde "Sosyolojinin kökeni ve temeli" olarak "Tarih" bilimini gören anlayışıyla birleşiri" ${ }^{13}$, beslendiği Ziya Gökalp ve Prens Sabahattin sosyolojilerini de dönüştürerek 1960'lardaki "Türkiye Sosyolojisi” yaklaşımını geliştirmesinde ona düşünsel zemin olur. ${ }^{14}$ Bunların yanında, Adana Erkek Muallim Mektebi'nde (1926-1931) hocası olan Arif Nihat Asya (1904-1975), Ankara Gazi Eğitim Enstitüsü'nde (1931-1935) hocası olan Ahmet Hamdi Tanpınar (1901-1962), 1943-1958 yılları arasında fikir paylaşımında usta-çırak ilişkisi içinde yakın olduğu Yahya Kemal Beyatlı (1884-1958), 1960'lı y1llarda fikirsel bağ kurduğu ve evindeki toplantılarda Bölüm'ün zihniyetini değiştirecek yaklaşımlar geliştirmekte ilham aldığ Kemal Tahir (1910-1973) ile 1963-1974 yılları arasında İstanbul Üniversitesi Edebiyat Fakültesi Sosyoloji Bölümü'nde ders veren Cemil Meriç (1916-1987) ${ }^{15}$, Cahit Tanyol'un bu düşünceyi ve yaklaşımı geliştirmesinde katkı veren, farklı dönemlerde bir arada olduğu fikir insanları ve düşünce kaynakları olur. ${ }^{16}$

Fügen Berkay'ın iddiası açısından gündeme gelen Baykan Sezer'in durumu ise şöyledir: Genç yaşta Kemal Tahir'in evinde Prof. Dr. Cahit Tanyol ile tanışan, Tanyol ile dostluğu olan babası Prof. Dr. Necdet Sezer'in ${ }^{17}$, Kemal Tahir'in ve Tanyol ile babasının bir diğer ortak dostu olan

\footnotetext{
${ }^{12}$ Cahit Tanyol, "Asyalı olmak” yaklaşımını, ilk düşüncelerinden itibaren güçlü biçimde savunur. Tanyol (1940, Ocak), Adana Erkek Muallim Mektebi'nde Edebiyat hocası olan Arif Nihat Asya hakkında yazdığı yazısında, "yabancılaşma" ve "aşağılık duygusu" ile bizde oluşan tavır ve tutumlara karşı "Asyalı olmak" ve "Tanzimat alafrangalığından kurtulmak" şeklide karşı çıkar, "Asya Rönesansı" için işaret fişeği atar: "Hem şu sahte Tanzimat alafrangalığından vazgeçerek artık şunu kabul etmemiz lazımdır ki: Biz Asyalıyız. Asyalı olmaktan kaçtığımız gündür ki, artık zavallı bir Parya [en alt tabaka] sürüsüyüz. Asya kendisine dönemediği içindir ki, dehasını kaybetti. Ve ruhlarını, çürük kumaşlara musallat olan bir güve gibi, Avrupa kemirmekte. Bu demek değildir ki, tekrar Buda mabedlerine Şarki tevekküle sürükleyen itikadlara döneceğiz. Asya bize yine Avrupa kanalından görünecek, kıtamıza kavuşmak gaye olmak şartıyla. (...) Asya bocalıyor; çünkü dehasını yabancı topraklarda, yabancı kaynaklarda araştırıyor. Küstah, şımarık ve katil Avrupa karşısında, Asya'nın korkunç ve muhteşem derinliği, baş döndürücü Mysticisme'i, ihtiyar ve afyonkeş bir fil hareketsizliğiyle ebediyyen uyuyamaz. Adımızı belahate [bönlüğe] sembol yapan hasta Avrupa'nın dejenere duyguları, Ganj'a ibadetler sunan ilahi Buda'nın velileri ve beyaz çadırlardan güneşe altın oklar atan kahramanların torunları kendilerine döndüğü gün, cüzzamlı bir hasta gibi Asya topraklarından kovulacak." Nisan 1939 ile Eylül 1940 tarihleri arasında 16 sayı İzmir'de, Eylül 1944'de 1 sayı İstanbul'da çıkan Aramak dergisinin nüshalarında Asyal1/Doğulu olduğumuz vurgusu için hem Cahit Tanyol'un hem de diğer yazarların yazılarında değerlendirmeler vardır. Aramak dergisi bibliyografyası için bkz. Çav, 2011: 672-680.

13 Tarih biliminin sosyolojinin temeli olmasına yönelik değerlendirmesi için bkz. Tanyol, 1973.

${ }^{14}$ Cahit Tanyol'un, 1950'li, 1960'l y1llardaki bu bağlamdaki değerlendirmeleri için bkz. Çav, 2011: 167-181, 181-205, 328-339, 339-354; "Medeniyet", "Demokrasi”, "Medeniyet ve Batılılaşma Süreci”, "Türk Toplumunda Devlet Felsefesi” başlıklı bölümler.

${ }^{15}$ Sosyoloji Bölümü'nün 1960'lardaki sosyoloji yaklaşımının değişiminde etkili olan Cemil Meriç'in Batı'yı çok iyi bilen, ama kendi toplumunun özelliklerini de dikkate alan yaklaşımları, Sosyoloji Bölümü’ndeki sosyoloji anlayışına Batı'ya karşı özgüvenli, yerli/yerel ve millî özellikleri olan yeni bir bakış açısı kazandırmıştır. Bu noktada, Cemil Meriç ile Kemal Tahir'in yakın arkadaş olduklarını da dikkate alırsak, bu iki ismin birlikte İstanbul Sosyoloji Geleneği'nde Türkiye/Anadolu merkezli, yani Selçuklu-Osmanlı-Türkiye tarihi ve coğrafyası merkezli bir bakış açısının yerleşmesinde etkili olduklarını söylemek mümkündür. Cemil Meriç'in bu yıllardaki derslerinin Ümit Meriç tarafindan kaleme alınmış metinleri için bkz. C. Meriç, 2006.

${ }^{16}$ Bu düşünce etkileşimleri için bkz. Çav, 2011: 87-112, 116-117, 393-396, 443-450, 450-452, 455-456 ve diğerleri; sırasıyla "Cahit Tanyol'un Sosyoloji Yaklaşımı", "Ziya Gökalp Sosyolojisi”, "Prens Sabahattin Sosyolojisi”, "Pragmatik Sosyoloji (Amerikan Sosyolojisi)", "Marksist Sosyoloji (Pragmatik ve 'Bize Göre')", "Kemal Tahir (1910-1973)", "Tarih Bilinci ve Tarih Eğitimi”, "Yahya Kemal Beyatlı (1884-1958)", "Ahmet Hamdi Tanpınar (1901-1962)" ve "Arif Nihat Asya (1904-1975)" ile diğer bölümler/sayfalar.

${ }^{17} \mathrm{Bu}$ yıllarda Prof. Dr. Necdet Sezer, alanında otorite kabul edilen çalışmaları olan, başarılı ve toplumda tanınan Tıp alanında önde gelen bir akademisyendir ve İstanbul Üniversitesi Cerrahpaşa Tıp Fakültesi’nde göz doktoru olarak görev yapmaktadır.
} 
felsefeci Prof. Dr. Vehbi Eralp'in referanslar $1^{18}$ ile akademide Cahit Tanyol'un desteğini alan Baykan Sezer ${ }^{19}$, doktorasın 1971 y1lında verdikten sonra ertesi y1l Eylül 1972'de Doktoralı asistan olarak Sosyoloji Bölümü’nde göreve başlar (Çav, 2011: 555). ${ }^{20}$ Dr. Baykan Sezer, "Türkiye Sosyolojisi” ve "Türk Sosyologları ve Eserleri" derslerini yürüten Prof. Dr. Cahit Tanyol'a derslerinde asistanlık yapar. Bu tarihsel bağlamda bakıldığında Cahit Tanyol, Sosyoloji Bölümü’nde "Türkiye Sosyolojisi” yaklaşımının öncüsü ve kurucusu olarak sosyoloji tarihindeki yerini alır ve Türkiye'de yerli/yerel ve millî sosyolojiyi inşa eden bir rol oynar. ${ }^{21}$ Bugün, ülkemizde, aktif olan 79'u devlet, 28'i vakıf olmak üzere 107 sosyoloji bölümündeki22 "Türkiye Sosyolojisi", "Yerli Sosyoloji" anlayışının kökeni ve/veya etkilendikleri merkez, temel olarak Prof. Dr. Cahit Tanyol'un danışmanlığında doktoralarını yapan Prof. Dr. Baykan Sezer ${ }^{23}$ (1939-2002), Prof. Dr. Fügen Berkay (d.1945) ${ }^{24}$, Prof. Dr. Sabahattin Gülllülü̈25 (d.1945), Prof. Dr. Ümit Meriç²6 (d.1946), Prof. Dr. Korkut Tuna ${ }^{27}$ (d.1944), Prof. Dr. Esin Küntay $^{28}$ (d.1937); Prof. Dr. Mahmut Arslan ${ }^{29}$ (d.1952), Dr. Mehmet Yalvaç ${ }^{30}$ (d.1942), Prof. Dr. Sami Şener ${ }^{31}$ (d.1949), Doç. Dr. Tuğrul Tanyol ${ }^{32}$ (d.1953) ve diğer 1960'l yıllardan bugüne İstanbul Üniversitesi Edebiyat Fakültesi Sosyoloji Bölümü'nde eğitimini alarak akademik çalışmaları ve fikirleri ile etkinlikleri devam eden sosyologlar ve akademisyenler aracıllı̆ı̆yla kolları temsil edilen İstanbul Üniversitesi Edebiyat Fakültesi Sosyoloji Bölümü'nün düşünce dünyası ve sosyoloji anlayışıdır. ${ }^{33}$ Dostoyevski'nin "Hepimiz Gogol'un paltosundan çıktık" sözünü bu bağ üzerinden şöyle kullanmak bir metafor olarak mümkündür: "Hepimiz Cahit Tanyol'un paltosundan çıtık."

\footnotetext{
${ }^{18}$ Cahit Tanyol, bu süreçte baskı altında kaldığını da dile getirmiştir (Yalvaç, 2020, 10 Ekim, telefon görüşmesi).

${ }^{19}$ Baykan Sezer, Tanyol'un, kendisinin akademik hayatındaki teşvik ediciliğini şöyle ifade eder: "Cahit Tanyol'la Kemal Tahir'in evinde tanıştım. Öğrenimimi sürdürmeye pek istekli değildim. Ailemin ısrarı ve Cahit Tanyol'un teşvikiyle öğrenimimi tamamladım” (Baykan Sezer'in Gökhan Göktürk'e Mektubu, 2004). Baykan Sezer (1998), bir diğer değerlendirmesinde ise Cahit Tanyol'un kendisine desteğini, Kemal Tahir'in üzerindeki etkisiyle birlikte şöyle ortaya koyar: "Bu yazı elinize geçtiği zaman ben emekli olmuş olacağım. İstanbul Üniversitesi Sosyoloji Bölümü’nde geçirdiğim yıllarda burada tümünün adını sayamayacağım çoğu kişiden destek gördüm. Başta belirtmem gereken görüşlerimin yönelmesini ve biçim kazanmasını Kemal Tahir'e borçluyum. Çoğu şeyi Kemal Tahir'den öğrendim. Çalışmalarımda bulunacak yanlış ve eksikler yalnızca benim Kemal Tahir'in iyi bir öğrencisi olmadığımı gösterir. Kendisini burada saygıyla anıyorum. Cahit Tanyol bana güvendi, Sosyoloji Bölümü’nde yanında çalışmama izin verdi. Kendisine her zaman teşekkür borçlu oldum.”

${ }^{20}$ Baykan Sezer'in asistanlığa aday olduğu dönemde asistanlık için adı geçenlerden biri olan Mehmet Yalvaç (2020, 7 Ekim, telefon görüşmesi) da bu süreci yaşayanlardandır.

${ }^{21}$ Türkiye'de "yerli sosyoloji” imkânının ele alındığı kapsamlı bir değerlendirme için bkz. Çav, 2019d. Yerli Sosyoloji araştırmasını tamamlayan biçimde; Cahit Tanyol ile Şerif Mardin'in sosyolojilerini ve yaklaşımlarını "Osmanlı Devleti'nin Çözülme, Tanzimat ve Çöküş Dönemleri”, "Türk Modernleşmesi”, "Kemalizm”, "Türkiye'de Toplum ve Devlet", "Türkiye'de Din ve Sekülarizm" başlıklarıyla ve temel düşüncelerini içeren diğer konularıyla birlikte karşılaştırmalı olarak inceleyerek ele aldığımız çalışmalar, Cumhuriyet tarihindeki sosyoloji konularının içeriğini ve aynı zamanda farklı sosyoloji akımlarının bunlar karşısındaki pozisyonlarını ortaya koyar (Çav, 2018a, 2018b, 2018c, 2019a, 2019b, 2019c).

22 Bölümlerin listesi için bkz. Sosyoloji Programı Bulunan Tüm Üniversiteler-YÖK, https://yokatlas.yok.gov.tr/lisansbolum.php?b=10195.

${ }^{23}$ Doktora tezi: “Doğu'da Yerleşik ve Göçebe Toplumların Sosyolojik Özellikleri Üzerine Bir Deneme”, 1971.

${ }^{24}$ Doktora tezi: "Yunus Emre'nin Türk Toplumundaki Yeri”, 1973.

${ }^{25}$ Doktora tezi: “Sosyoloji Açısından Ahi Birlikleri”, 1973. Güllülü, Doktorasını Erzurum Atatürk Üniversitesi’nden almış, ancak tez danışmanlığını konuyu kendisine öneren Cahit Tanyol yapmıştır.

26 Doktora tezi: “Ahmet Cevdet Paşa'nın Cemiyet ve Devlet Görüşü”, 1975.

${ }^{27}$ Doktora tezi: "Yurtdışında Çalışma Olayının Sosyolojik Eleştirisi”", 1975.

${ }^{28}$ Doktora tezi: "Ailedeki Çözülmenin Çocuk Suçluluğuna Etkileri Üzerine İstanbul Çevresinde Yapılmış Bir Araştırma”, 1976.

${ }^{29}$ Doktora tezi: "Göçebelerde Sosyal ve Siyasal Kuruluş”, 1977.

30 Doktora tezi: "Türkiye'de Örf ve Adet Değişmeleri Açısından Küçük Yerleşim Birimlerinin Sosyolojik Görüntüsü", 1979.

${ }^{31}$ Doktora tezi: “[Mansurîzade Mustafa Nuri Paşa'nın yazdığı] Neteyiç' ül Vukukat'ın Işı̆̆ında Osmanlı Hükümet Yapısında Değişme -Kuruluş’tan Tanzimat'a Kadar-", 1980.

${ }^{2}$ Doktora tezi: "İnsanın Toplumsal ve Tarihsel Yapısı Üzerine Bir Model Denemesi”, 1980.

${ }^{33}$ Cahit Tanyol'un, 1970'lerde yaptırdığı diğer doktora tezleri de "Türkiye Sosyolojisi” anlayışını yansıtır: Hasan Küçük

"Tarikatların Türk Toplumundaki Sosyal Fonksiyonları", Bahattin Can "Türkiye'de Dinsel Eğitimin Tarihsel Kaynakları ve Gelişimi” ve Adil Çağlar “Bir Geçiş Döneminde (1938-1950) Türk Aydını”. Cahit Tanyol'un, aynı yıllarda İran'dan
} 
İddialar ve tarihsel süreç bağlamında incelediğimizde, bizim kanaatimiz, Fügen Berkay'ın bu iddiasının aşırı yorum ve/veya zorlama olacağı yönündedir. Sebeplerine eğilelim. Öncelikli olarak Baykan Sezer'in, doktora danışmanlığını yapan, kendisini Sosyoloji Bölümü'ne alan ve Bölüm'deki faaliyetlerinde her zaman kendisine destek olan Bölüm Başkanı Prof. Dr. Cahit Tanyol'a karşı böyle bir tavırda olmasını beklemek ahlâkî olarak zayıf bir ihtimaldir. Bununla birlikte, Bölüm Başkanlığı'nın son yıllarında Prof. Dr. Cahit Tanyol ile Doç. Dr. Baykan Sezer arasında, Bölüm Başkanı olduktan sonra ise Doç. Dr. Baykan Sezer ile Sosyoloji Bölümü öğretim üyesi bazı isimler arasında çeşitli çatışmalar yaşanmıştır. ${ }^{34}$ Ancak, bu çatışmaların, başta Cahit Tanyol'un üç yazısının

gelen Fars ve Türk öğrencilere yaptırdığı doktora tezleri de konular bazında bakıldığında İran'ın "Yerli Sosyoloji”" anlayışına katkı vermesi bakımından dikkate değerdir: Hasan Sabuncu Rizapur “İran'da Dinin Sosyal Etkisi”, Behruz Parsi “İran'da Eğitim ve Öğretimin Toplum Üzerine Olan Etkisi, Ahed Zerforuşan "İran'da Toprak Mülkiyeti”, N. Purefkarî "İran Çingenelerinin Sosyal Yapısı Üzerine Bir Araştırma", Perviz İlmî "İran'da Verginin Sosyal ve Ekonomik Hayatta Etkisi”, Mirzaaga Pouramouz “Tebriz Çevresindeki Köylerde Örf ve Adetler”, Ahad Behdjat "Meşrutiyet Öncesi İran'da Sınaî Ekonominin Gelişmesi", Najieh Bolourchian "Tebriz ve Çevresindeki Tapınaklar", Madjid Farsiani "Sosyoloji Açısından Horasan Sarbadaran Hareketi”, Muhammad Homayoun M. "İran'da Örf ve Adetlerin Değişmelerinin SosyoEkonomik Nedenleri: Hasaban Zirai Anonim Ortaklığı Örneği”, Firouz Jeddi "Şiraz’lı Sadi’nin Toplum ve Eğitim Dünyası", Naser Sifosadaty Niry "İran Kirman Eyaletinde Yaşayan Göçebe Toplulukların Örf ve Adetleri Üzerine Bir İnceleme" (Çağlar, Kayıp Dergi: 467-468).

${ }^{34} \mathrm{Bu}$ çatışmaların, Cahit Tanyol'un İstanbul Sosyoloji Geleneği'ndeki [İstanbul Ekolü'ndeki] yerinin ve düşünce dünyasının İstanbul Üniversitesi Edebiyat Fakültesi Sosyoloji Bölümü eksenindeki kapsamlı bir değerlendirmesi için bkz. Çav, 2011: 553-563. Prof. Dr. Cahit Tanyol'un 13 Temmuz 1982 tarihindeki emekliliğinden sonra Doç. Dr. Baykan Sezer ile Doç. Dr. Fügen Berkay (2020, 7 Ekim, telefon görüşmesi) ve Dr. Mehmet Yalvaç (2020, 7 Ekim, telefon görüşmesi) gergin bir ilişki sürecine girerler. Fügen Berkay (2020, 7 ve 12 Ekim, telefon görüşmesi), "köklerimden koptuğum" ve "unutmak istediğim" yıllar dediği İstanbul Üniversitesi Edebiyat Fakültesi Sosyoloji Bölümü'den ayrılması sürecinde, yeni Bölüm Başkanı olan Baykan Sezer'in baskılarının etkisinin olduğunu dile getirir. Berkay (2020, 12 Ekim, telefon görüşmesi), 1970'li yıllarda diğer Bölüm üyelerinden önde tutulduğunu iddia ettiği Baykan Sezer'e yönelik bu desteği sebebiyle "Baykan, Bölüm'ün kimyasını bozdu" diyerek hocası Cahit Tanyol'a karşı uzun bir dönem kırgınlık tașır. Görevinden ayrılmayı kesinlikle düşünmeyen, yurt dışına giderek Doçentlik çalışmalarını tamamlamak isteyen, ancak bu yaşanan çatışmalı yıkıcı süreç sebebiyle Bölüm'den ayrıldığını dile getiren Mehmet Yalvaç (2020, 10 Ekim, telefon görüşmesi) da bu baskıların tanığı ve yaşayanı durumundadır. Yalvaç (2020, 7 ve 10 Ekim, telefon görüşmesi), Fügen Berkay'ın ilk Doçentlik tezinin sebepsiz yere reddedilerek haksızlığa uğradığını ve Doçent olduktan sonra da kadro konusunda Bölüm yönetiminden olumlu yaklaşım gelmediğini, kendisinin de Cahit Tanyol'a karşı Baykan Sezer tarafından alınan olumsuz tavır ve Hocanın oğlu Tuğrul Tanyol'un Doktora tezi raporunun nasıl yazılacağı gibi konularda Baykan Sezer'le çeşitli çatışmalar yaşadığını dile getirir. Baykan Sezer, [kızkardeșinin oğlu] yeğeni Mahmut Arslan'ın doktora yapıp Bölüm'de göreve başlamasına izin vermesinden ve oğlu Tuğrul Tanyol'a Bölüm'de doktora yaptırmasından dolayı "nepotizm [akraba kayırmacılığı] yaptığını" söyleyerek Cahit Tanyol'a tepki gösterir [Yalvaç, 2020, 10 Ekim, telefon görüşmesi; Berkay, 2020, 12 Ekim, telefon görüşmesi). Bu bask1 ve çatışma ortamında Fügen Berkay (2020, 7 ve 12 Ekim, telefon görüşmesi) "çil yavrusu gibi dağıldık" şeklinde tanımladığı dönemde Şubat 1984'te, "Baykan Sezer ile çatışma yaşamasam İstanbul Üniversitesi'nden ayrılmazdım” diyen Mehmet Yalvaç (2020, 10 Ekim, telefon görüşmesi) ise Mayıs 1984 tarihinde, Türkiye'de sosyolojinin merkezi konumunda olan İstanbul Üniversitesi Edebiyat Fakültesi Sosyoloji Bölümü’nden ayrılarak ve/veya ayrılmak zorunda kalarak/bırakılarak Bölüm'e kırgın biçimde "kader birliği” içerisinde y1llarca birlikte çalışacakları Malatya İnönü Üniversitesi'ne giderler, orada Sosyoloji Bölümü'nün kuruluşunu gerçekleştirirler. Fügen Berkay (2020, 12 Ekim, telefon görüşmesi), emekliliğine yakın yıllarda Cahit Tanyol'a karş1 Baykan Sezer tarafından haksızlık yapıldığını söylerken, Mehmet Yalvaç (2020, 7 Ekim, telefon görüşmesi) da çeşitli girişimlerle Cahit Hocanın "Bölüm'den kaçırtılmak istendiğini” dile getirir. Yaşından dolayı 1982'de emekli olduktan sonra, kişisel daveti ile kendisini ziyarete giden ve henüz İstanbul'dan ayrılarak Malatya'ya gitmemiş olan Fügen Berkay (2020, 7 Ekim, telefon görüşmesi) ve Mehmet Yalvaç'a hitaben Cahit Tanyol, Bölüm'e aldığı Baykan Sezer ile ortaya çıkan çatışmalar, Bölüm'deki huzursuzluk ve yaşadıkları sıkıntılar sebebiyle davetine icabet eden öğrencilerine yönelik "Ya çocuklar, geldiniz ha, yüzüme bakmasanız haklısınız" demiştir. Fügen Berkay ve Mehmet Yalvaç, 1984 yılından bugüne, ayrıldıkları Sosyoloji Bölümü'nün üyelerinden bazıları ile sosyoloji etkinliklerinde zorunlu olarak bir-iki kez, bazıları ile hiçbir zaman görüşmemişlerdir. Bölüm'ün bir diğer üyesi Ümit Meriç (2020, 7-9 Ekim, görüşme) de Baykan Sezer ile bir süre gerginlik yaşar, fakat sonrasında karşllıklı olarak süreci yumuşatırlar. Ümit Meriç (2020, 7-9 Ekim, görüşme; 2020, 7 Ekim, dörtlü telefon görüşmesi), geçtiğimiz birkaç yılda yaptı̆ğ bir ziyarette Cahit Tanyol'un kendisine hitaben şunları söylediğini aktardı: "Hayatımda iki tane hata yaptım: Birisi Baykan'ı Doktor yapmak, öbürü seni Doktor yapmamak." Nurettin Şazi Kösemihal'in vefatı sonrasında Ümit Meriç'in Doktora Tez Danışmanı Cahit Tanyol olur. Tez savunması sürecinde, zaman sınırı sebebiyle bir ay içinde tezi okuyup rapor yazması gereken Cahit Tanyol, tezi okumaz ve rapor vermez. Bu durum Fakülte Kurulu'nda gündeme geldiğinde Tanyol önce "Tezi bana getirmedi” der. Bunun üzerine Dekan "Tezin takibini yapmak sizin görevinizdi" der. Tanyol, buna cevaben bu sefer "Tezi ben vermedim" der. Dekan, Ümit Meriç'in tez dosyasının getirilmesini ister. Dosya getirilip incelendiğinde Cahit Tanyol'un konuyu verdiğine dair 
bulunduğu ve diğer Bölüm üyelerinin de katkı verdiği bir derginin, Kayıp Dergi’nin yayınını engelleyecek bir davranışa, tavra ve eyleme dönüşeceğini düşünmenin, bugünden bakıldığında düşük bir ihtimal olacağı kanaati ağır basmaktadır. Öte taraftan, başta belirttiğimiz gibi taraflar hayatta olmadıkları için bu konuda kesin bir değerlendirme yapmak mümkün değildir. Bunun yanında, Kayıp Dergi'nin basım tarihi 1983'tür. Yani, Cahit Tanyol'un 13 Temmuz 1982'deki emekliliğinden sonra derginin prova ve/veya iç kısmının basımı yapılmıștır. Dolayısıyla, bu dönemde İstanbul Üniversitesi Edebiyat Fakültesi Bölüm Başkanı olan Baykan Sezer'in eğer bir sansür düşüncesi var ise derginin basımını baştan engellemesi daha mantıklı olurdu. Bu açıdan, Kayıp Dergi'nin sansüre uğramasında Baykan Sezer'in isteğinden, talebinden ve/veya uygulamasından ziyade, dönemin Darbe Rejimi güç merkezlerinden, Üniversite Yönetimi'nden ve/veya Dekanlıktan (veya Fakülte Yönetim Kurulu üyelerinden) gelen tepkilerin, uyarıların, baskıların veya engellemelerin etkili olduğunu söylemek daha yerinde gözükür. Bununla birlikte, Kayıp Dergi'ye yönelik bu sansür uygulamasına karşı, Sosyoloji Dergisi'nin yönetimini yürüten Sosyoloji Bölümü’nün Başkanı olarak Doç. Dr. Baykan Sezer'in yeterli ölçüde direnmediği ve/veya direnemediği, Bölüm'ün uhdesindeki dergiyi, dolayısıyla Bölüm üyelerinin ve diğer akademisyenlerin akademik ve fikrî özgürlüklerini her koşulda ve durumda bütün gücüyle savunmadığı ve/veya savunamadığı dile getirilebilir. $\mathrm{Bu}$ süreçte Bölüm'de görev yapan ve derginin basılmış fakat ciltlenmemiş formalarını, basılı metinlerini gören Korkut Tuna (2020, 7 Ekim, telefon görüşmesi), Baykan Sezer ile bir kere konuştuktan sonra, ileriki yıllarda, 1983 yılından 1998 yılına değin birlikte geçirdikleri 15 yıllık ortak çalışma süreci boyunca Kayıp Dergi konusunun bir daha gündeme gelmediğini belirtti. Bu anlamda "Kayıp Dergi Olayı"nın, sonraki yıllarda Baykan Sezer, Bölüm, Dekanlık ve Üniversite açısından tamamen gündemden kaldırıldığını söylemek mümkündür.

\section{3.İhtimal-Sebep-Yaklaşım: Cahit Tanyol'un Atatürkçülük Yaklaşımı}

Kayıp Dergi'ye yönelik sansür için üçüncü ihtimal, Cahit Tanyol'un “Atatürk Devrimleri ve Hoca Kadri Efendi” başlıklı makalesinde dile getirdiği ve 12 Eylül 1980 Darbesi ile ihdas edilmek istenen Atatürkçülük anlayışı ile yüzde yüz örtüşmeyen, hatta bir din adamına atıfla devrimlere düşünsel kaynak oluşturması sebebiyle çelişen ve bir ölçüde çatışan bir içeriğe sahip makalesi olabilir. Cahit Tanyol, Atatürk devrimlerine Osmanlı din adamı Hoca Kadri Efendi'den dayanaklar gösterdiği makalesinde, bir yönüyle devrimlerin din-dışı olmadığı iddiasını da ortaya koymuş olur. Darbe Rejimi'nin İÜEF Sosyoloji Dergisi'nde çıkacak böyle bir yazıdan rahatsız olarak Üniversite yönetimine bask1 yapması ihtimalini düşünen "karar vericiler", Kayıp Dergi'nin sansüre uğramasında etkili olmuş olabilir. Fakat, Kayıp Dergi'ye "Atatürkçülügün ve devrimlerin farklı değerlendirilmesi" sebebiyle sansür uygulanması ihtimalinin, "irticâ̂" sebeple sansür uygulanması ihtimalinden daha düşük olduğunu öngörebiliriz. Bununla birlikte, Kayıp Dergi’nin, hem "Atatürkçülüğü ve devrimleri farklı yorumlayan" makale hem de "irticâ̂" odaklı yorumlanan makale/makaleler sebebiyle, iki olguya da dayandırılarak sansüre uğramış olabileceği ihtimali de yok sayılamaz.

imzalı belgenin olduğu görülür. Bunun üzerine Fakülte Kurulu'nda Cahit Tanyol’un Jüri Başkanlığı düşürülür. Devamında, boşalan Jüri Başkanlığına Jüri Üyesi Prof. Dr. Mehmet Kaplan, boşalan üyeliğe de yeni üye olarak Doç. Dr. Erol Güngör getirilir. Güngör tezi kısa sürede okur. Bir hafta içinde Doktora Savunması günü planlanır. Jüri karşısında tezini başarıyla savunan Ümit Meriç en yüksek not "Pekiyi" ile Doktor olur (Meriç, 2020, 7-9 Ekim, görüşme). Bu sayede Ümit Meriç, doktorasını veremeyip asistanlıktan ve akademiden ayrılmak zorunda kalmak gibi bir süreçle de karşılaşmaz. Bu, kimi zaman kişisel yönleri ağır basan çatışmalı durumlar, İstanbul Üniversitesi Sosyoloji Bölümü’nün tarihinde, Darülfünun döneminde 1914'teki kuruluşundan itibaren yaşanır: İçtimâiyat Kürsüsü döneminde Ziya Gökalp (1876-1924) ile ABD'den doktorasını yapıp gelen Ahmet Emin Yalman (1888-1972); Bölüm'ün 1941'de başlatılan yeniden yapılanma ve aktif olma sürecinden sonra Hilmi Ziya Ülken (1901-1974) ile Hasan Tanrıkut (1917-1981) ve Nurettin Şazi Kösemihal (1909-1972); Nurettin Şazi Kösemihal ile Cahit Tanyol (1914-2020); Cahit Tanyol ile Turhan Yörükan (d.1927), Ayda Yörüken (19281993), Muzaffer Sencer (1940-1995) ve Oya Baydar (d.1940) arasında yaşanan gerilimli süreçler, yukarıda aktardıklarımızın geçmişteki birer versiyonu gibidir. Bütünlüklü olarak bakıldığında, İstanbul Üniversitesi Edebiyat Fakültesi Sosyoloji Bölümü'nün, kuruluşundan bugüne adeta gelenek hâline gelen yıpratıcı iç çatışmalarla ciddi olarak enerjisini harcadığını, bunun da akademisyenlerin entelektüel üretimlerini olumsuz etkilediğini söylemek mümkündür. 


\section{4.İhtimal-Sebep-Yaklaşım: Maddi Kaynak Sorunu}

Kağıt bulamama ve/veya diğer maddi sebeplerle Kayıp Dergi'nin basımının iptal edilmiş olma ihtimali çok düşük olmakla birlikte, imkânsız değildir. Bir şekilde maddi sebepler kullanılarak Kayıp Dergi'nin basımının geciktirilmesi, yeterli kağıdın alınmaması ve/veya matbaa masrafları için ödenek çıkarılmaması gibi işlemler "fikrî sansür" için bahane olarak kullanılmış olabilir. En düşük ihtimal olmakla birlikte eğer maddi sebepler yayını engellemiş olsa, bu durum basımı bir süre daha erteleyebilirdi, ancak bu seçenek de hiç basılmaması ile sonuçlanacak şekilde Kayıp Dergi'yi tamamen ortadan kaldırmazdı. Dolayısıyla, bu yaklaşım ihtimaller dâhilinde olsa bile, belirleyici sebep olarak görülemez.

\section{Kayıp Dergi ile Bağlantılı Akademisyenlerin Görüşleri}

Prof. Dr. Haluk Yavuzer [d.1944. 1983 yılında İstanbul Üniversitesi Edebiyat Fakültesi Eğitim Bilimleri'nde Doçent olarak görev yapmaktadır ve Kayıp Dergi Yayın Kurulu üyesidir] (2020, 13-14 Ekim, telefon görüşmesi), Prof. Dr. Cahit Tanyol'un Sosyoloji Dergisi'nin 23-24. sayısının basılabilmesi için "Yayın Kurulu" üyesi olması teklifi yaptı̆̆ını ve kabul ettiğini dile getirdi. Günümüzde hayattaki tek "Yayın Kurulu" üyesi olan Yavuzer (2020, 13-14 Ekim, telefon görüşmesi), "Yayın Kurulu üyesi olma teklifi" görüşmesi dışında Kayıp Dergi'den haberdar olmadığını, bizim gerçekleştirdiğimiz telefon görüşmesi esnasında ilk kez şaşkınlıkla yaşanan bu sansür olayını dinlediğini, o güne değin hiç duymadığını dile getirdi. Yavuzer (2020, 13-14 Ekim, telefon görüşmesi), karşılaştığımız bu olayın bilimsel açıdan kabul edilebilir olmadığını söyledi. Kayıp Dergi'nin basılmış formalarının yanmamışsa, buharlaşmamışsa, yok olmamışsa halen Üniversite Matbaası'nda olabileceği umudunu taşıyan Yavuzer (2020, 13-14 Ekim, telefon görüşmesi), eğer bu derginin sansürle sonuçlanan akıbeti konusunda o yıllarda bilgisi olsaydı bu işin peşini asla bırakmamış olacağını, mutlaka derginin basımının ve dağıtımının gerçekleşmesi için mücadele etmiş olacağını, ancak ifade ettiği gibi gelişmelerden hiç haberinin olmadığını özellikle vurguladi.

Prof. Dr. Korkut Tuna [d.1944. 1983 y1lında Sosyoloji Bölümü’nde Dr. Asistan olarak görev yapmakta ve derginin hazırlıklarında yer almaktadır] (2020, 7-8 Ekim, telefon görüşmesi), ilk anda dergiyi hatırlamadı. Tuna, Kayıp Dergi'nin tarihinden, özelliklerinden ve içeriğinden bahsettikçe büyük bir şaşkınlıkla süreci hatırlamaya başladı. "Bir sayı bir sebepten yok edilmişti" diyerek söze başlayan Tuna (2020, 7-8 Ekim, telefon görüşmesi), Baykan Sezer'in derginin bu hâlini kendisine gösterdiğini belirtti. Tuna, derginin bir sebepten basılmadığını, ancak bu sebebi Sezer'in açık bir şekilde söylemediğini ifade etti. Sonrasında 15 yıl daha Bölüm'de birlikte çalışacakları dönemde bir kez dahi bu derginin gündeme gelmediğini ve üzerine konuşulmadığını belirten Tuna, 7 Ekim 2020 tarihli telefon konuşmamıza değin gelen bu denli bir unutturulmuşluğun, susturulmuşluğun, sindirilmiş̧liğin inanılmaz olduğunu belirterek, yaşadığı duyguyu tarif etmekte zorlandı. "Dergi neden yok edildi?" sorumuza Korkut Tuna (2020, 7 Ekim, telefon görüşmesi) "Olmadık bir yazı mı sıkışmış araya, derginin bir ayıbı olacak o yazı sebebiyle o dergi öyle basılmadı. Böyle hayal meyal hatıllıyorum. Öyle yarım kalmış bir dergimiz var" dedi. Ancak, Tuna, "olmadık" ve "derginin bir ayıbı olacak" yazının hangi yazı olduğunu hatırlamadı. Tuna, Kayıp Dergi'nin fasiküller halinde basılıp basılmadığı konusunda tam emin olamadı, prova baskısının/baskılarının yapılmış olma ihtimalini de yüksek tuttu. Kayıp Dergi'yi "Fantom", yani "Hayalet" dergi olarak tanımlayan Tuna'nın (2020, 8 Ekim, telefon görüşmesi), dergi hazırlıklarında bulunmasına rağmen bile hatırlamakta zorlandığı ama nihayetinde çeşitli detaylarını anımsadığı olaya yönelik bugünkü yaklaşımı şöyledir: Bu dergi gerçekten önemlidir, tarihidir, bir an önce bu hatanın 40 yıl sonra dahi olsa düzeltilmesi gerekir, Kayıp Dergi’nin tıpkıbasımının yapılması yerinde olur. ${ }^{35}$ Korkut Tuna'nın

\footnotetext{
${ }^{35}$ Korkut Tuna (2020, 8 Ekim, telefon görüşmesi), "Dergiyi bulan, dergiyi basar" şeklinde bir ifadeyle bu görevi bize vermiştir. Ancak incelediğimiz üzere dergideki yazılardan 2 tanesi kesin, 3 tanesi temkinli bir yorumla basılmamış olmakla birlikte kalan 10 makalenin tamamı yayınlanmıştır. Dolayısıyla, hem bu durum hem de Sosyoloji Dergisi'nin bir devamı
} 
yaptığı değerlendirme, Kayıp Dergi’nin Türk sosyolojisinin karanlık bir dönemine yaptığ1 göndermenin mutlaka aydınlatılması, düzeltilmesi gerektiğidir.

Prof. Dr. Fügen Berkay [d.1945. 1983 yılında Sosyoloji Bölümü’nde Doçent olarak görev yapmaktadır ve Kayıp Dergi'de makalesi vardır] (2020, 7 Ekim, telefon görüşmesi), dergi çalışmalarını ve dergiyi hatırladı, ancak basılıp basılmadığından aynı şekilde Korkut Tuna gibi emin olamadı. Konuşuldukça sürecin ayrıntılarını hatırlayan Berkay (2020, 7 Ekim, telefon görüşmesi), Kayıp Dergi'nin bir sebepten basılmadığını ve bunun Bölüm'de bir şekilde gündeme geldiğini belirtti. Berkay (2020, 7 Ekim, telefon görüşmesi), Kayıp Dergi'nin bir nevi "akademik iktidar" boyutu olan bir dinamiğin ve/veya çatışmanın kurbanı olabileceğini belirtti. Bu olayın kesinlikle "tarihi" bir olay olduğunu söyleyen Berkay (2020, 7 Ekim, telefon görüşmesi), 1967-1984 yılları arasında 17 yıl görev yaptığı İstanbul Üniversitesi Edebiyat Fakültesi Sosyoloji Bölümü açısından, içindeki makalelerle birlikte döneminde belirleyici bir fikir kaynağı olduğunu düşündüğü Kayıp Dergi'nin akıbetinin aydınlatılmasının önemine işaret etti.

Prof. Dr. Ümit Meriç [d.1946. 1983 yılında Sosyoloji Bölümü’nde Dr. Asistan olarak görev yapmaktadır ve Kayıp Dergi'de makalesi vardır] (2020, 7-9 Ekim, görüşme), çalışmasını verdiğini ve dergi yayın sürecini hatırlamadı, makalesinin bu şekilde dizilip basılmaya hazır hale geldiğini, diğer yazarlar gibi Kayıp Dergi' yi görene kadar öğrenmedi. Türkiye düşünce ve sosyoloji birikimine önemli bir katkı sunan makalesinin yayınlanmamış olmasının hayal kırıklığını yaşayan Ümit Meriç (2020, 7-9 Ekim, görüşme), yaptığı değerlendirmede, kendi çalışmasında Kur'an'ı Kerim'den yaptığı ayet alıntısının ve Muzaffer Ozak'a yaptığı ithafın Kayıp Dergi'nin sansürlenmesinde başlıca sebep olduğunu düşünmektedir. ${ }^{36}$

Dr. Mehmet Yalvaç [d.1942. 1983 yılında Sosyoloji Bölümü'nde Okutman olarak görev yapmaktadır ve Kayıp Dergi'de makalesi vardır] (2020, 7 Ekim, telefon görüşmesi), sahip olduğu kesin bilgi ile "irticai içerik" sebebiyle derginin yayınlanmadığını hatırladığını belirtti. Bu değerlendirme, yaptığımız görüşmeler içerisinde ortaya çıkan en çarpıcı tespit idi. Kayıp Dergi'nin basılma çalışmalarını bilen, kendisinin makalesi de bu sayıda yayınlanmak için alınan Mehmet Yalvaç (2020, 7 Ekim, telefon görüşmesi), Kayıp Dergi için dönemin İstanbul Üniversitesi Edebiyat Fakültesi Dekanı Prof. Dr. Sencer Tonguç’a gidilerek "Dergide irticaî yazı var" şeklinde ihbarlar yapıldığını, bu sebeple derginin iptal edilerek yayınlanmadığını net biçimde söyledi. Bir diğer sebep olarak Bölüm içi çatışmaların bir boyutu olarak derginin bu şekilde kadük kalmış olabileceğini düşünen Yalvaç'a (2020, 7 Ekim, telefon görüşmesi) göre, Kayıp Dergi, 12 Eylül 1980 Darbesi koşullarındaki olağanüstü ve kritik dönemde çeşitli bahaneler bulunarak/uydurularak yayınlanmamıştır.

Prof. Dr. Mahmut Arslan [d.1952. 1983 y1lında Sosyoloji Bölümü’nde Dr. Asistan olarak görev yapmaktadır ve Kayıp Dergi'de makalesi vardır] (2020, 8 Ekim, telefon görüşmesi), dergide yazısı olan Bölüm'ün üyesi bir akademisyen olarak dergi hazırlıklarını hatırlamış, ancak sürecin tamamlanmadığını bilerek takibi bırakmıştır. Arslan (2020, 8 Ekim, telefon görüşmesi), derginin orijinal metinlerinin Medrese geleneğinden gelen İstanbul Üniversitesi Edebiyat Fakültesi'nin arşivlerinde olabileceğini dile getirmiş ve yeniden basım için bundan faydalanılabileceğini belirtmiştir.

olarak Kayıp Dergi’nin İstanbul Üniversitesi'nin sahip olduğu isim ve telif hakları sebebiyle bu şekilde tıpkıbasımının yapılması hemen hemen imkânsız görünmektedir.

36 Ümit Meriç (2020, 7-9 Ekim, görüşme), dergi sürecini hatırlamamakla birlikte, kendisinin, örgün eğitime ara verildiği 1983 'ün yaz ayında, Muzaffer Ozak ve çevresindeki grup ile birlikte yapılacak olan ziyarete katılarak ABD'ye gitmesine dönemin İstanbul Üniversitesi Edebiyat Fakültesi Dekanı Prof. Dr. Sencer Tonguç tarafından izin verilmediğini dile getirmiştir. Bu durumun sebebini öğrenmek veya bu kararın Kayıp Dergi'deki makale ile ilgili olup olmadığını cevaplamak, Tonguç hayatta olmadığı için mümkün değildir. 
Doç. Dr. Bedri Mermutlu [d.1953. 1983 yılında öğretmen olarak çalışmaktadır ve Kayıp Dergi'de makalesi vardır] (2020, 8 Ekim, telefon görüşmesi), Kayıp Dergi'deki Ziya Gökalp'in ders notlarını Arapça harflerden (Eski Türkçeden/Osmanlıcadan) Latinize ederek günümüze aktaran çalışmasını 1980-81 tarihlerinde Korkut Tuna'nın kendisini telefonla arayarak istediğini belirtti. Yazısını çeşitli düzeltmelerle yeniledikten sonra Korkut Tuna'ya gönderdiğini, ancak sürecin devamını bilmediğini belirten Mermutlu (2020, 8 Ekim, telefon görüşmesi), yayın konusunda somut bir gelişme olmayınca ilgili makaleyi 1995 yılında Genç Sosyologlar Derneği'nin Türk Sosyoloji Dergisi'nde bastırdığını söyledi.

Ahmet Kot [d.1953. 1978 yılında İngiltere'de, Londra'da bir yandan gazetecilik yaparken aynı zamanda Dr. Ümit Meriç'in çalışmasına katkı verir, 1983 yılında Yayıncılıkla meşguldür] (2020, 8 Ekim, telefon görüşmesi), yayın süreci bilgisine sahip değildir, görüşmede öğrenir. Londra British Library'de Türkiye ve İslâm konulu eserlerin bibliyografyasını çıkararak Ümit Meriç'in makalesine büyük katkı veren Kot (2020, 8 Ekim, telefon görüşmesi), sosyoloji alanında çalışmış biri olarak, önemli bir içeriğe sahip makalenin akademik araştırmalar için kaynak bulmanın çok zor olduğu o yıllardaki önemine işaret etti, yayınlanmış olsa çok büyük bir boşluğu doldurmuş olacağını, bu sebeple özel bir önem ve tarihi değer taşıdığını vurguladı. Türk fikir hayatı ve sosyolojisi için dünya çapında önem taşıyan böyle bir makalenin ve derginin toplumla buluşmasının engellenmesinin kabul edilebilir bir tutum olmadığını dile getiren Ahmet Kot (2020, 8 Ekim, telefon görüşmesi), Kayıp Dergi'nin tıpkıbasımının yapılmasının o günlerde yaşanan sansürcü akademik zihniyeti de ortaya çıkaracağına dikkat çekti.

\section{Değerlendirme ve Sonuç}

1941 yılında İstanbul Üniversitesi Edebiyat Fakültesi Sosyoloji Kürsüsü’nün yeniden kurulmasın1, yapılanmasını ve aktif olmasını ve Sosyoloji Dergisi'nin aynı y1l ikinci cilt/seri/dizi olarak yeniden yayın hayatına başlamasını sağlayan Ord. Prof. Hilmi Ziya Ülken anısına hazırlanan ve ön-baskısı yapılan 1983 tarihli 23-24. Sayı "Sosyoloji Dergisi" sansürlenmiştir. "Kayıp Dergi Olayı", alelade, basit, görmezden gelinebilecek, sıradanlaştırılabilecek ve unutulabilecek bir sansür olay1 değildir. Aksine, Türkiye'deki düşünce ve sosyoloji tarihini saptıran, İstanbul Sosyoloji Geleneği/Ekolü ve ülke genelindeki sosyoloji gelenekleri/ekolleri üzerinde zihniyet, düşünce, çalışmalar ve yaklaşımlar açısından etkilere yol açan, telafisi mümkün olmayan kayıplar getiren, özgür ve bağımsız bilim yapma anlayışına ağır bir darbe vuran, yapanların her zaman utancı olacak ve Türkiye'nin akademi, düşünce, siyasi ve sosyal tarihinde her zaman hatırlanacak kara bir sansür olayı olarak kayıtlara geçmiştir.

Bugüne değin, Türkiye sosyoloji tarihini yazan tüm metinlerin önemli bir boşluğu dolmuştur. Bu boşluğun adı, İstanbul Üniversitesi Edebiyat Fakültesi Sosyoloji Dergisi'nin 1917 yılından itibaren çıkan tüm nüshalarının en yüksek sayfa sayılı ikinci nüshası olarak tasarlanan ve Sayı 23-24 olarak planlanan 476 sayfalık "Kayıp Dergi”dir. 22 Temmuz 2020 günü keşfettiğimiz bu Kayıp Dergi, İstanbul Üniversitesi Edebiyat Fakültesi adına Sosyoloji Bölümü'nün çıkardığı Sosyoloji Dergisi'nin bu "Kayıp Halkası", günyüzüne çıkmış, çevresinde örülen karanlık zihniyet ve yaklaşım, düşünce ve uygulama; 38 yıl sonra dahi olsa, bağımsız düşüncenin aydınlığı ile, bugün kırılmıştır. Kayıp Dergi, "gizli bir el” tarafından sessiz-sedasız sansürlenerek ortadan kaldırılmıştır. Dergiden haberdar olan, yazıları toplayan ve/veya Kayıp Dergi'de yazıları bulunan, süreci sisli olarak anımsayan, ancak üzerine detaylı konuşmalarla olayı daha net olarak hatırlamaya başlayan akademisyenlerin şaşkınlıkları ise, bu sansürün, bilinçaltına itilen travmatik boyutları olduğuna, keskin, sert ve güçlü bir "bireysel bastırma" mekanizmasının devreye girdiğine işaret eder.

"Kayıp Dergi Olayı", Türkiye'nin akademik hayatında, üniversite ve düşünce tarihinde önemli bir sansür uygulamasıdır. Ortaya çıkan Kayıp Dergi, bir "hafıza kaydı" olarak düşünce tarihimizin karanlık bir noktasına 1şık tutmaktadır. Dönemin ortamı, 12 Eylül 1980 Darbesi ile gelen "Darbe Rejimi”" koşullarıdır. Kafaların omuzların üzerinde dik duramadığı, durdurulmadığı, 
durmasına izin verilmediği askerî yönetim zamanlarıdır. Böyle bir ortamda, herhangi bir "yanlış/falso" Bölüm'ün, Fakülte'nin, Üniversite'nin ve Yükseköğretim Kurumu'nun aleyhine olabilirdi ve ilgili yöneticilerin makamlarını, mesleklerini ve kariyerlerini kaybetmeleri, hatta mahkemelerde yargılanmaları anlamına gelebilirdi. Kayıp Dergi'nin başına gelen şey, "karanlık hava" içerisinde kendini inşa eden ve rahatça her istediğini yapabilen "baskıcı gücün" düşünceye yaptığı sansür uygulamasıdır. Sansürün; yani baskı, örtme, sümenaltı etme, kapatma, karartma, engelleme ve yok etme pratiklerinin işletilmesinin sonsuz çeşidinden bir tanesi olarak incelediğimiz bu olay, tasarımı tamamlanmış prova baskısı ve/veya iç baskısı yapılmış bir derginin yayınlanmasının engellenmesi olarak tezahür etmiştir. Türkiye tarihinde, sayısız sebebi ve sayısız pratiği olan sansürün somutlaşmış uygulamalarından bir tanesi “Kayıp Dergi Olayı” olmuştur.

Kayıp Dergi'nin hazırlanma süreci ve akıbeti ile ilgili olarak görüştüğümüz dönemin Sosyoloji Bölümü üyelerinin ortak görüşü; böylesine önemli, tarihi ve kritik bir olayda Sosyoloji Bölümü'nün her bir üyesinin susturulduğu, konunun unutturulduğu, üzerinin örtüldüğü ve geri gelmemesi amacıyla tarihin karanlık sayfalarına bırakıldığıdır. Kayıp Dergi'den bahsettikçe, görüşülen ilgili tüm taraflar süreci hatırlamış, bildiklerini ve yaşadıklarını aktarmaya başlamışlardır. Yapılan derinlikli görüşmelerde, bu sürecin, İstanbul Üniversitesi Edebiyat Fakültesi Sosyoloji Bölümü adına mutlaka aydınlatılması gereken "karanlık" bir olay olduğu düşüncesi, genel kabul görmüştür.

Dergideki 15 makalenin 10 tanesi kesin olarak yayınlanmıştır. Cahit Tanyol'un 1967 yılında Madrid'te yaptığı sunumun metni ve Ümit Meriç'in makalesi kesin olarak basılmamıştır. Tayyib Gökbilgin, İbrahim Yasa ve Adil Çağlar'ın yazıları konusunda kesin neticeye varılamamıştır. Bununla birlikte yayınlanan diğer 10 makalenin durumları ile ilgili olarak da Türkiye'deki düşünce ve sosyoloji tarihine zarar veren süreçler işlemiştir. Dergi, dönemine göre ileri seviyede bir zihniyetle, paylaştığı bilgilerle, taşıdığ dönüştürücü yaklaşımıyla İslâm Sosyolojisi bağlamında önemli makaleler içermiş, ancak bu makaleler akademi, düşünce dünyası ve toplum ile buluşma imkânı bulamamıştır. Cahit Tanyol'un "Le fondement social du droit de l'Islâm", yani "İslâm Hukukunun Sosyal Temeli" başlıklı konuşması ve Ümit Meriç'in, 120 sayfalık 1875 kitap, 81 süreli yayın ve 4 ansiklopedinin bilgisini içeren "İslâm Sosyolojisi İçin Bir Bibliyografya Denemesi" başlıklı makalesi, Türkiye'deki İslâm Sosyolojisi çalışmalarını o yıllar açısından bakıldığında farklı biçimlerde etkileyebilecek dikkat çekici metinlerdir. Özellikle Ümit Meriç'in makalesi, dünyadaki İslâm çalışmalarını, İslâmî kaynaklar ile İslâm düşüncesi ve sosyolojisi üzerine eserleri listeleyen içeriği ile Türkiye'de bu konudaki akademi-üniversite düzeyindeki çalışmaların gelişimini belirleyebilecek, yön verebilecek ve yeni araştırmalara zemin hazırlayabilecek önemli bir "Kaynak Bibliyografya" makalesidir. Bu iki makalenin, bugüne değin yayınlanmamış olması, Türkiye'deki düşünce ve sosyoloji birikimi açısından bir kayıptır.

Bir an için farklı düşünelim ve Kayıp Dergi'nin, dolayısıyla dile getirdiğimiz İslâm düşüncesi merkezli makalelerin yayınlandığını tasavvur edelim. Türkiye'nin din ile sekülarizm bağlamında yaşadığı süreçler dikkate alındığında Ümit Meriç'in makalesi 1980'lerde yükselen çatışmalı süreçlere karşı fikrî çözümler getirme bağlamında önemli bir katkı sunabilirdi. Daha somut bir değerlendirme ile 1983 yılında dinin toplumsal etkilerinin tartışılmasının imkânı sansürsüz, baskısız ve engelleme olmadan açılabilmiş olsayd1, bundan başta düşünce dünyamı, üniversite, toplum ve devlet olumlu yönde etkilenir, her bağlamdaki uç fikirlere ve uygulamalara karşı daha dengeli yaklaşımlar geliştirilebilirdi. Türkiye Sosyolojisi'nin merkezi İstanbul Üniversitesi Edebiyat Fakültesi Sosyoloji Bölümü'nün yönetiminde çıkan Sosyoloji Dergisi bağlamında, Sosyoloji Bölümü, Edebiyat Fakültesi ve İstanbul Üniversitesi Kayıp Dergi’yi sansürlemek yerine yayınlanmasını sağlayarak böyle bir sorumluluğu almış olsaydı, bu adım, sonraki yıllarda yaşanacak din-sekülarizm eksenli siyasi ve toplumsal çatışmaları olumlu yönde dengeleyen akademik birikimli bir seçeneği geliştirme imkânı verebilirdi. Böylece, 1980'lerden bugüne gündemin hiç bitmeyen 
konusu olan din-sekülarizm tartışmaları; daha bilimsel, anlamlı ve somut çalışmalar üzerinden yapılır, Türkiye'nin din-sekülarizm (laikleştirme) uygulaması ekseninde yaşadığı tarihsel, siyasal ve toplumsal gerilim hattı zayıflatılabilir ve hatta belki de 28 Şubat 1997 Darbesi'nin ve/veya darbe koşullarının bile daha yumuşak bir şekilde aşılmasına katkı sunulabilirdi.

Öte taraftan, İstanbul Üniversitesi Edebiyat Fakültesi Sosyoloji Bölümü’nün 1912-1982 tarihleri arasındaki tarihinin hocalar, dersler ve çalışmalar bağlamında ayrıntılı dökümünü veren, bugün bütün sosyoloji tarihi çalışmalarında atıf yapılan Mehmet Yalvaç'ın "İstanbul Üniversitesi Edebiyat Fakültesi'nde Sosyoloji Eğitiminin Tarihçesi (1912-1982)" başlıklı önemli makalesi de Edebiyat Fakültesi'nin uhdesinde ve Sosyoloji Bölümü'nün yönetiminde olan akademik dergide yayınlanamamış, bu açıdan İstanbul Üniversitesi Sosyoloji Bölümü tarihinin, Bölüm’ün kendi üniversite dergisinde ve akademik çevresinde daha sağlıklı biçimde tartışılmasının imkânı zayıflatılmıştır. Yalvaç'ın makalesi 1985 yılında Kubbealtı Dergisi'nde yayınlanabilmiş, ancak Üniversite dışında basılmış olması sebebiyle önemine rağmen uzun yıllar akademik çevrelerde yeterli dikkati çekmemiştir.

Bu koşullar altında bakıldığında, çok yönlü fikrî tartışmalara kapı açabilecek, çeşitli yeni incelemeleri tetikleyebilecek ve içeriği ile dönüştürücü yaklaşımlar sunabilecek Kayıp Dergi'nin akademi, düşünce dünyası ve toplumla buluşamamış olması, Türkiye'deki düşünce hayatı ve sosyoloji birikimi için önemli bir kayıp olmuştur. Başka bir ifade ile Kayıp Dergi, 1983 yılında Üniversite yayını olarak basılmış olsaydı ülkemizin fikir dünyası için önemli bir kazanım olur, gerek İstanbul Sosyoloji Geleneği/Ekolü gerekse Türkiye'deki düşünce ve sosyoloji birikimi farklı bir derinliğe ve zenginliğe o yıllarda erişebilirdi. Sansür, bu imkânı yok etmiştir.

Kayıp Dergi'nin yayınlanmasının engellenmesi, Türkiye'nin siyasi ve sosyal tarihi açısından, darbelerin karanlık ortamı altında gelişen müdahaleci ve yıkıcı süreçlerin, öz olarak "sansür uygulamalarının" Akademideki bir yansımasıdır. Bu örnek olay ve daha nice benzeri olaylar; akademik bağımsızlı̆g korumakta yetersiz kalan Bölüm, Fakülte ve Üniversite yönetimlerinin hem içe hem dışa dönük olarak yaşadığı sansür uygulamalarının bir uzantısıdır. ${ }^{37}$ "Kayıp Dergi Olayı" ile Türkiye'nin entelektüel birikimi ve düşünce tarihi bağlamında önemli bir olgu açığa çıkmıştır: Düşünceyi engelleme, sansür ve yok etme pratiklerine sahip zihniyetleri taşıyan kurumlar ve yöneticileri, Cumhuriyet tarihi boyunca çeşitli dönemlerde düşünceye ve entelektüel birikime engelleyici müdahaleler yapmış, bir nevi düşünme ve düşünce yıkımı gerçekleştirmişlerdir.

Şunu vurgulamak gerekir: Sansür amaçlı baskı, örtme, sümenaltı etme, kapatma, karartma, engelleme ve/veya yok etme pratiklerini sadece kişiler üzerinden okumak hakikati tüm boyutları ile vermez. İstanbul Üniversitesi Edebiyat Fakültesi adına dergiyi hazırlayan Sosyoloji Bölümü’nün makaleleri toplanmış, dizilmiş, tasarımı bitmiş ve prova baskıları yapılmış bir dergisinin yayından çekilmesi hadisesi olarak gerçekleşen sansür uygulaması, Türkiye'deki genel akademik zihniyet ve sistem ile "dönemin ruhu" üzerinden okunarak ancak tüm boyutları ile anlaşılabilir. Darbe Rejimi sürecinde gerçekleşen bu tekil olay sadece bir örnektir. Dönemin içinde bu şekilde benzer olayların, birçok kamu kurumunda, farklı üniversitelerde, sivil toplum örgütlerinde, hatta özel şirketlerde ve toplumun farklı yapılarında çeşitli biçimlerde yaşandığını düşünmek, anlamsız değildir. 12 Eylül 1980 Darbesi'nin, birçoğu 7-10 yıl sonra mahkeme kararı ile geri dönecek 1402'liklerle Akademi'de getirdiği hoca kıyımının yanında, bu çalışmada ele aldığımız olay da bu yıkım uygulamasının bir başka boyutunu ve örneğini vermesi bakımından tarihe not düşülmesi zorunlu olan, kötü/olumsuz ve kabul edilemez bir deneyimdir. Bu kötü/olumsuz deneyimin, iyiye/olumluya çevrilmesi, zihniyet değişimini sağlayacak bir dönüşümle mümkündür. Toplamda bakıldığında, Kayıp Dergi Olayı; bireyler/akademisyenler açısından travmatik/psikolojik boyutlar içerir, bürokrasi açısından sansür/kamu yönetimi uygulaması gösterir, toplum açısından yasakçı/sosyolojik yansımalar ortaya

\footnotetext{
${ }^{37}$ Bu sürecin bir boyutunda, 12 Eylül 1980 Darbesi sonrasında kurulan Yükseköğretim Kurumu'nun (YÖK) da yer aldığını belirtmek gerekir.
} 
koyar, Türkiye Düşünce tarihi için engelleme/sansür işlemi getirir ve devlet açısından tek tipçi baskıcı yönetim/totaliterlik paradigmasını besler.

İstanbul Üniversitesi Edebiyat Fakültesi bünyesinde yer alan ve Sosyoloji Bölümü tarafindan yönetilen Sosyoloji Dergisi'nin 23-24. sayısı olarak tasarlanan, 1980-1981 tarihlerine işaretlenen ve 1983 Yılında ÏÜEF Fakülteler Matbaası'ndan basılarak bir araya getirilen Kayıp Dergi hakkındaki çeşitli bilgi, belge ve görüşleri ortaya koyduk. Önümüzdeki zamanlarda umuyoruz ki, süreci yaşayanların ve/veya bilgisine sahip olanların yeni değerlendirmeleriyle, yıkıcı bir sansür deneyimini ortaya koyan Kayıp Dergi Olayı'nın diğer gizli kalan yönleri, uygulamadaki farklı özellikleri, karar vericilerin konumları, akademideki, sosyolojideki ve Türkiye düşünce tarihindeki etkileri daha geniş boyutta ele alınacaktır.

\section{Kaynakça}

Arslan, M. (1984). Step Imparatorluklarında Sosyal ve Siyasi Yapı. İÜEF Yayınları.

Arslan, M., Çav, E. \& Meriç, Ü. (2020, 8 Ekim). Üçlü telefon görüşmesi.

Baykan Sezer'in Biyografisi ile İlgili Sorulara Verdiği Cevaplar (2004). Baykan Sezer'e Armağan: Baykan Sezer ve Türk Sosyolojisi (Sosyoloji Yıllığı 11) içinde (23-30) (Haz. E. Eğribel ve U. Özcan). Kızılelma Yayınları.

Baykan Sezer'in Gökhan Göktürk'e Mektubu (2004). Baykan Sezer'e Armağan: Baykan Sezer ve Türk Sosyolojisi (Sosyoloji Yıllığı 11) içinde (31-35) (Haz. E. Eğribel ve U. Özcan). Kızılelma Yayınları.

Berkay, F. (1987). Genel Boyutları İçinde Yurtdışına İşü̈cü Göçü Olayı ve Bazı Sorunlar. İnönü Üniversitesi Sosyal Bilimler Dergisi, 1, 161-167.

Berkay, F. \& Çav, E. (2020, 12 Ekim). Telefon görüşmesi.

Berkay, F., Çav. E., Meriç, Ü. \& Yalvaç, M. (2020, 7 Ekim). Dörtlü telefon görüşmesi.

Boratav, P. N. (1982). Folklor ve Edebiyat II. Adam Yayınları.

Boratav, P. N. (1993, Ekim). Mudurnu Türküleri. Toplumbilim (Türk Toplumbilimi Özel Sayısı), 2, 51-66.

Boratav, P. N. (2017). Folklor ve Edebiyat II. BilgeSu Yayınları.

Çav, E. (2011). Dramın Aydını Cahit Tanyol: Şair-Öğretmen-Felsefeci-Sosyolog. Kesit Yayınları.

Çav, E. (2018a). İki Sosyoloji Akımının Temsilcisi Cahit Tanyol ile Şerif Mardin'in Eğitimleri, Çalışma Hayatları, Eserleri ve Sosyal Bilime Katkıları Üzerine Karşılaştırmalı Bir İnceleme. Çekmece - İstanbul Sabahattin Zaim Üniversitesi Sosyal Bilimler Dergisi, 6(12), 29-62.

Çav, E. (2018b). Türk Modernleşmesi: Cahit Tanyol ile Şerif Mardin'in Yaklaşımlarının Karş1laştırmalı İncelemesi. Turkish Studies - International Periodical For The Languages, Literature and History of Turkish or Turkic, 13(26), 341-375. http://dx.doi.org/10.7827/TurkishStudies.14313

Çav, E. (2018c). Türkiye'de Toplum ve Devlet: Cahit Tanyol ile Şerif Mardin'in Yaklaşımları Üzerinden Karşılaştırmalı Bir İnceleme. Karadeniz Uluslararası Bilimsel Dergi, 40, 328373. http://dx.doi.org/10.17498/kdeniz.414361

Çav, E. (2019a). Osmanlı Devleti'nin Çözülmesi, Tanzimat ve Çöküş Dönemleri: Cahit Tanyol ile Şerif Mardin'in Yaklaşımlarının Karşılaştırmalı İncelemesi. Turkish Studies - Historical Analysis, 4(1), 53-84. http://dx.doi.org/10.7827/TurkishStudies.14367 
Çav, E. (2019b). Türkiye'de Din ve Sekülarizm: Cahit Tanyol ile Şerif Mardin'in Yaklaşımlarının Karşılaştırmalı İncelemesi. Turkish Studies - Comparative Religious Studies, 14(1), 17-95. http://dx.doi.org/10.7827/TurkishStudies.14859

Çav, E. (2019c). Kemalizm: Cahit Tanyol ile Şerif Mardin'in Yaklaşımlarının Karşılaştırmalı İncelemesi, Turkish Studies - Social Sciences, 14(3), 365-408. http://dx.doi.org/10.29228/TurkishStudies.22565

Çav, E. (2019d). "Türkiye'de 'Yerli Sosyoloji' İmkânı: Cahit Tanyol ile Şerif Mardin'in Yaklaşımlarının Karşılaştırmalı İncelemesi”, Karadeniz Uluslararası Bilimsel Dergi, 43, 78120. http://dx.doi.org/10.17498/kdeniz.556634

Çav, E., Meriç, Ü. \& Mermutlu, B. (2020, 8 Ekim). Üçlü telefon görüşmesi.

Çav, E. \& Meriç, Ü. (2020, 7-9 Ekim). Görüşme.

Çav, E. \& Yalvaç, M. (2020, 10 Ekim). Telefon görüşmesi.

Çav, E., Kot, A. \& Meriç, Ü (2020, 8 Ekim). Üçlü telefon görüşmesi.

Çav, E., Meriç, Ü. \& Tuna, K. (2020, 7-8 Ekim). Üçlü telefon görüşmesi.

Çav, E., Yavuzer, H. \& Meriç, Ü. (2020, 13-14 Ekim). Üçlü telefon görüşmesi.

Denbigh, K. (1984). İlmi Metod: Düzen mi, Özgürlük mü? (Çev. Ü. Meriç). İÜIF Sosyoloji Konferanslart, 22, 25-42.

Gürhan, N. \& Yücedağ İ. (2020). Türk Sosyolojisinde Değişen Eğilimleri Anlama Denemesi: Sosyoloji Dergisi Örneği. Turkish Studies, 15(5), 2421-2448. https://dx.doi.org/10.7827/TurkishStudies.42845

Ercan, R. (2007). Türkiye'de Sosyolojinin Gelişiminde Dergilerin Rolü ve Önemi: İstanbul Üniversitesi Sosyoloji Dergisi (Yayınlanmış Doktora Tezi). Cumhuriyet Üniversitesi Sosyal Bilimler Enstitüsü Genel Sosyoloji ve Metodoloji Anabilim Dal1.

Ercan, R. (2013). Türkiye'de Sosyolojinin Gelişimi ve Eğilimleri. Anı Yayıncılık.

İstanbul Üniversitesi Edebiyat Fakültesi Sosyoloji Bölümü Tarihçesi, https://sosyolojiedebiyat.istanbul.edu.tr/tr/content/hakkinda/bolum-tarihi, E.t. 10 Ekim 2020.

İstanbul Üniversitesi Edebiyat Fakültesi Sosyoloji Dergisi Dijital Arşivi (1917-2020), https://dergipark.org.tr/tr/pub/iusosyoloji/archive, E.t. 9 Ekim 2020.

İstanbul Üniversitesi Sosyoloji Dergisi Web Sitesi, https://dergipark.org.tr/tr/pub/iusosyoloji, E.t. 9 Ekim 2020.

Kayış, N. \& Hürkan, S. (2012). Sansürsüz Sansür Tarihi (1795-2011). Sinemis Yayınları.

Meriç, C. (2006d). Sosyoloji Notları ve Konferanslar (10. Baskı). İletişim Yayınları.

Meriç, Ü. (1985, Temmuz-Ağustos). İslâm Sosyolojisi Bibliyografyası Üzerine. İlim ve Sanat, 2, 97 100.

Meriç, Ü. \& Kot, A. (1987, Mayıs-Haziran). İslâmiyetle İlgili Seçme Yayınlar: Bir Bibliyografya Denemesi (İngilizce, Almanca, Fransizca). Ilim ve Sanat, 13, 81-87.

Meriç, Ü. (1994) Yayınlanmamış Notlar: 1994 Yılı Ajandası.

Mermutlu, B. (Haz.) (1995). Ziya Gökalp'in Üniversite'de Okutmuş Olduğu İlm-i İçtimâ Dersleri. Türk Sosyoloji Dergisi, 1, 119-164.

Prof. Dr. İbrahim Yasa’ya Armağan (1983). Ankara Üniversitesi Basımevi. 
Sezer, B. (1989). Türk Sosyologları ve Eserleri I. IÜEF Sosyoloji Dergisi, 3(1), 1-96.

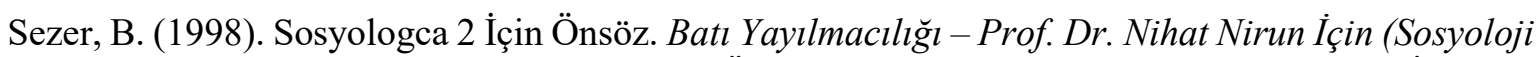

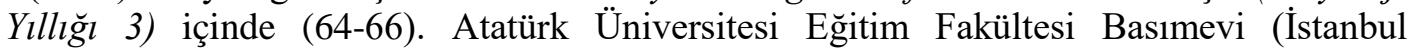
Üniversitesi Edebiyat Fakültesi Sosyoloji Araştırma Merkezi ve Atatürk Üniversitesi FenEdebiyat Fakültesi Sosyoloji Bölümü).

Sosyoloji Programı Bulunan Tüm Üniversiteler-YÖK, https://yokatlas.yok.gov.tr/lisansbolum.php?b=10195, E.t. 9 Ekim 2020.

Tanyol, C. (1939, Nisan). Aramak. Aramak, 1, 1.

Tanyol, C. (1940, Ocak). Arif Nihad Asya Hakkında. Aramak, 9, 2-9.

Tanyol, C. (1940, Eylül). Japon Mitolojisi. Aramak, 16, 11-15.

Tanyol, C. (1973). Türk Sosyolojisinin Bazı Sorunları. Cumhuriyetin 50. Yılına Armağan içinde (429-432). İstanbul Üniversitesi Edebiyat Fakültesi.

Tanyol, C. (2003). Hoca Kadri Efendi'nin Parlamentosu. Gendaş Yayınları.

Tanyol, C. (2006) Hilmi Ziya Ülken’in Kişiliği ve Düşünce Dünyası. Hilmi Ziya Ülken Kitabı, içinde (XXIV-XXVI) (Haz. A. Vergili). Kitabevi Yayınları.

Tanyol, T. (1987). Toplumsal-Kültürel Yapı ve Kişilik Kuramlarına Genel Bir Yaklaşım. Marmara Üniversitesi İIBF Dergisi, 4(1-2), 575-598.

Tayyib Gökbilgin Bibliyografyası, http://tayyibgokbilgin.info/turk-macar-yakinligi/, E.t. 9 Ekim 2020.

Vergili, A. (2006). Hilmi Ziya Ülken Kitabı. Kitabevi Yayınları.

Yalvaç, M. (1985, Ocak). İstanbul Üniversitesi Edebiyat Fakültesi'nde Sosyoloji Eğitiminin Tarihçesi (1912-1980) I. Kubbealtı Akademi Mecmuast, 14(1), 57-72.

Yalvaç, M. (1985, Nisan). İstanbul Üniversitesi Edebiyat Fakültesi'nde Sosyoloji Eğitiminin Tarihçesi (1912-1980) II. Kubbealtı Akademi Mecmuası, 14(2), 59-72.

Yılmaz, M. \& Doğaner, Y. (2007). Cumhuriyet Döneminde Sansür (1923-1973). Siyasal Kitabevi. 


\section{Ekler}

Ek 1: Kapak sayfası [Saman kağıd1] [Sosyoloji Dergisi 23-24. sayısı olan Kayıp Dergi'nin ciltlenmiş nüshasının ön-dış kapağında herhangi bir ibare, işaret veya başlık yoktur].

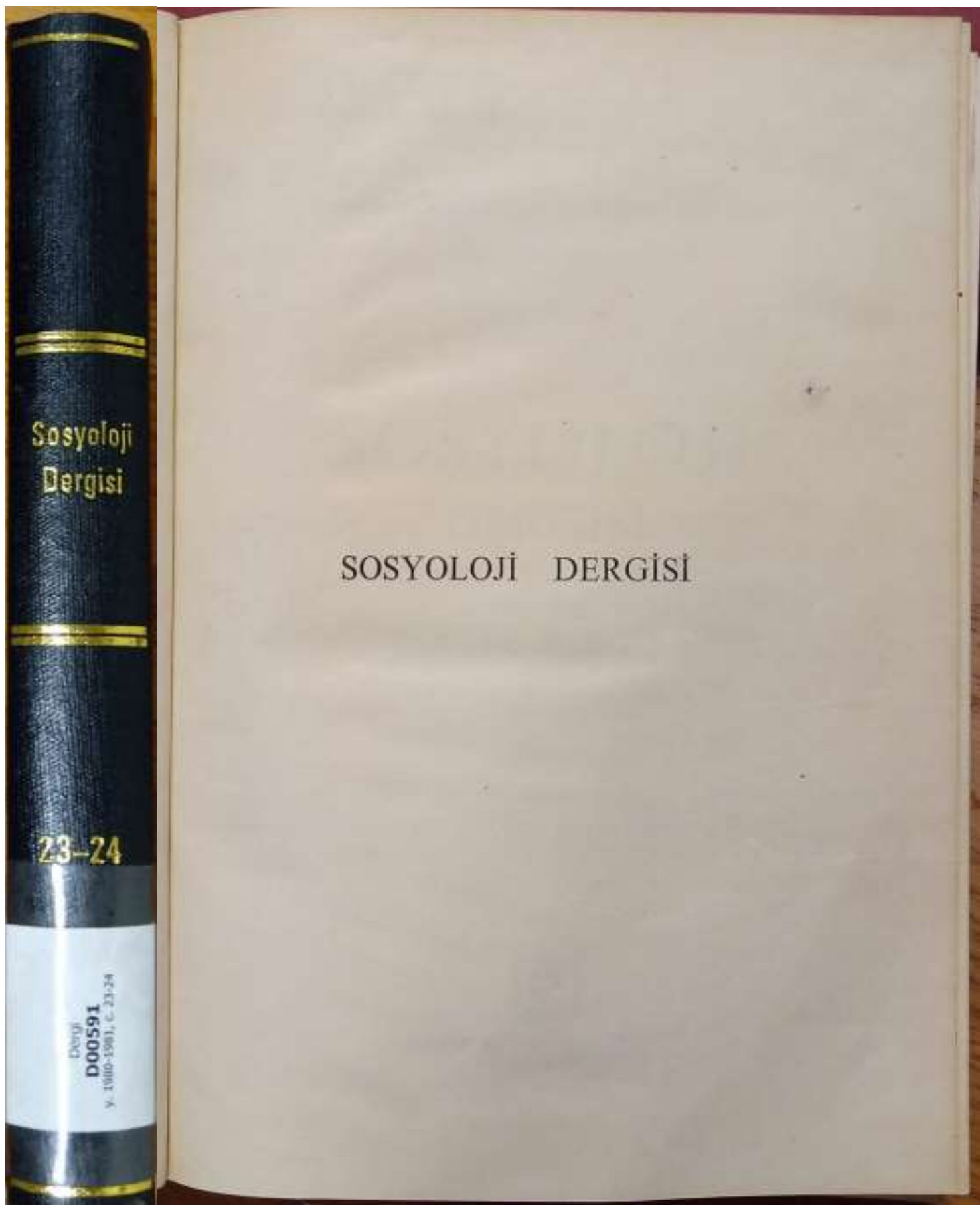


Ek 2: Basımevi bilgisi sayfası.

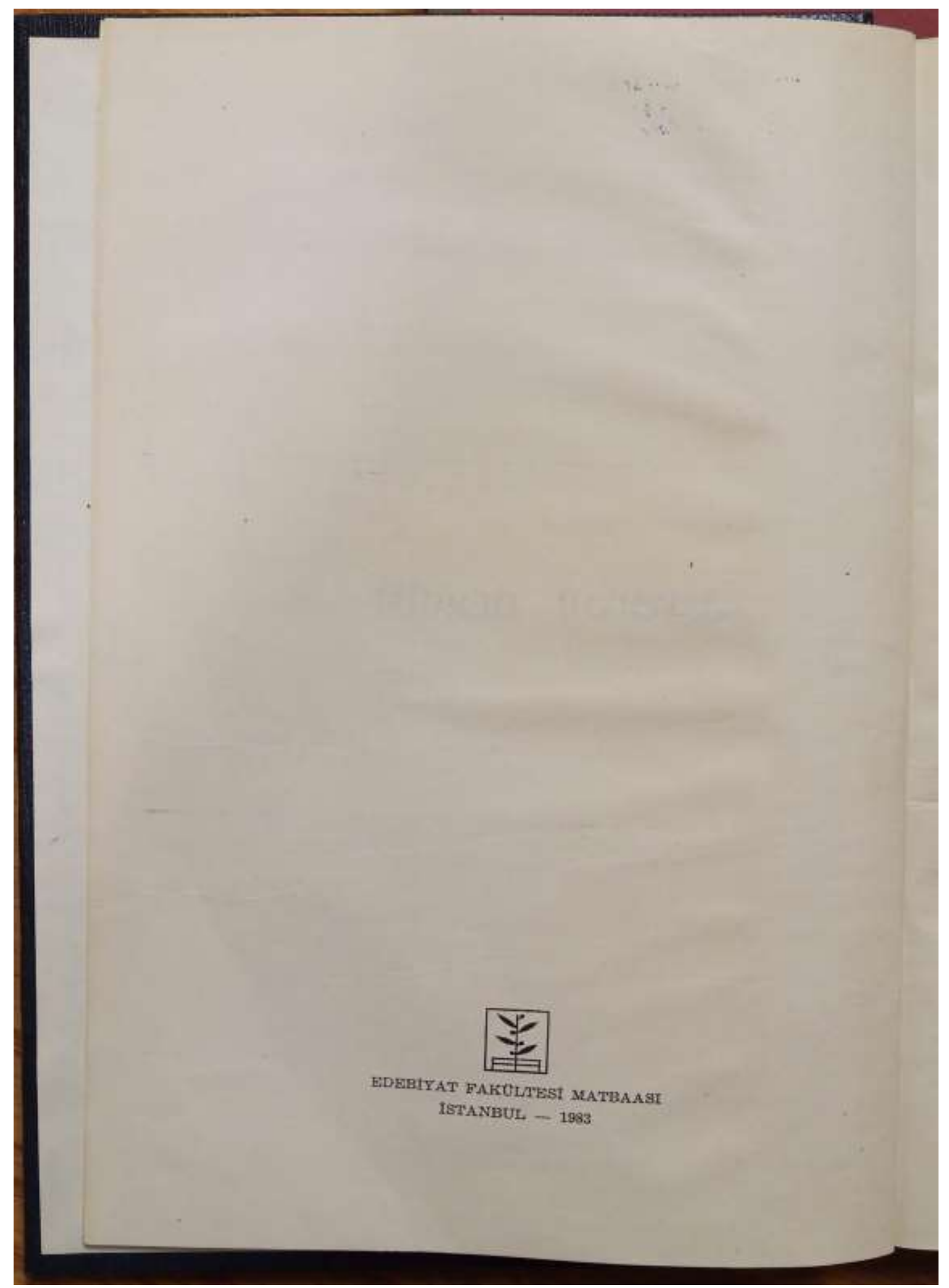


Ek 3: İç kapak sayfası.

\section{Prot. Dr, Bayken SEzer}

KItaplig:

E. Eg̈ribet ve U. Özcan Bagısi

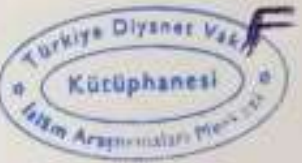

ISTANBUL UNIVERSITESI EDEBIYAT FAKULTESI

\section{SOSYOLOJI \\ DERGISI}

$1980-1981$

Sayı : $23-24$

Kurucusu

Ord. Proi. Hilmi Ziya OLKEN

EDEBLYNT EAKOLTESI MEATBAASI

ISTANELL - 1983 
Ek 4: Yayın kurulu sayfasi.

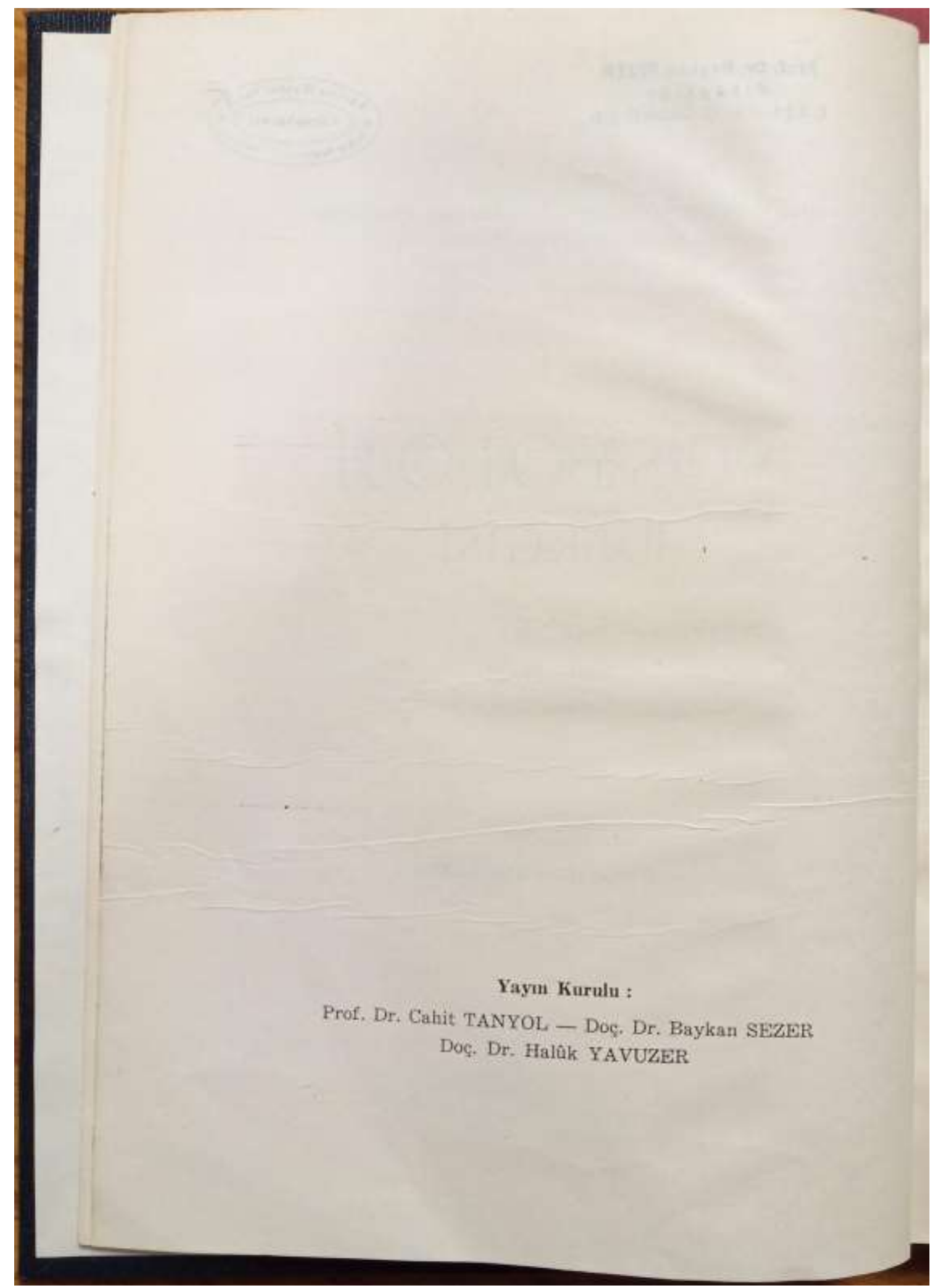

www.turkishstudies.net/turkishstudies 
Ek 5: Ord. Prof. Hilmi Ziya Ülken'e ithaf sayfası.

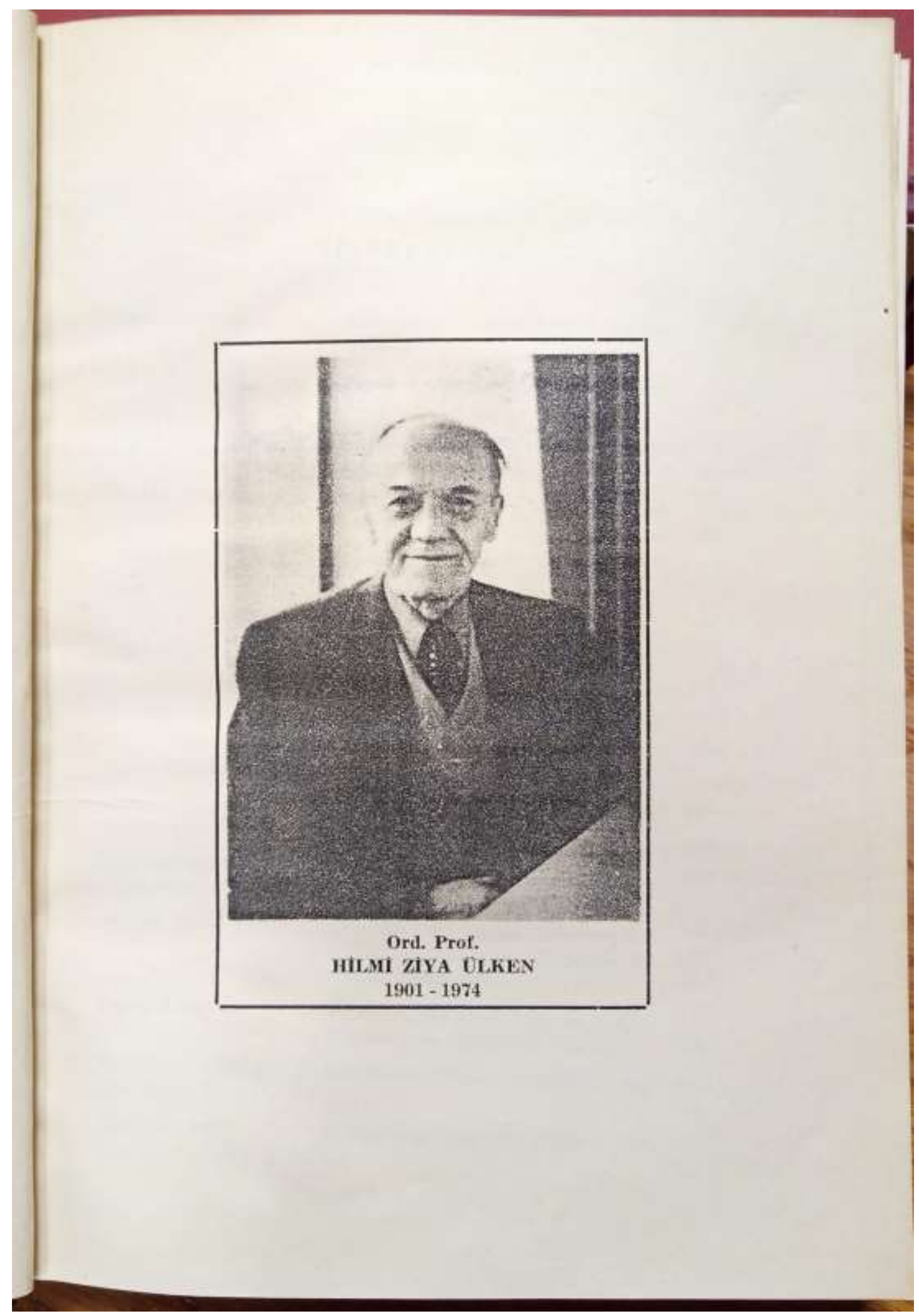

Turkish Studies, 16(1) 
Ek 6: İçindekiler sayfası.

I CINDEKILER

Cahit TANYOL

Hilmi Ziya Ulken in Kişiligi ve Ditsuince Dilinyası

Cahit TANYOL Atatïrk Devrimieri ve Hoca Kadri Efendi

1

5

Tayyib GOKBILGIN

Ibrahim YASA

Pertev Naili BORATAV

Cahit TANYOL

Umid MERTÇ

Mahmut ARSLAN

Figen BERKAY

Bnylkan SEZER

Taya GOKALP

(Haz. Bedri Mermut)

Mehmet YALVAC

Twgrrul TANYOL

Koneth DENBIGH

(Qev. Umid Meriç)

Aál GAGLAR
Macaristan'daki Türk Idaresi fle 11. gili Bazı Kaynaklar

Tradition of Mutual Aid in Turkish Villages

Le Fondement Social du Droit de I'Islam

fslâm Sosyolojisi Için Bir Bibliyografya Denemesi

Step Imparatorluklarında Eikonomik ve Sosyal Yapı

Genel Boyutları Isinde Yurt Disıına Isguicủ Góciu Olays ve Bazı Sorunlar

Yurdumuzda Sosyoloji

lim-i Içtimã' Dersleri

Istanbul Universitesi Edebiyat Fakültesinde Sosyoloji Eğitiminin Tarihçesi (1912-1982)

Toplumsal-Killteürel Yapi ve Kisillik Kuramlarına Genel Bir Yaklisım 423

Ilmi Metod: Diizen mi, Hürriyet mi? 449

Kiirsumizde Yaptlan Daktora Tezleri 
Ek 7: Prof. Dr. Cahit Tanyol'un “Hilmi Ziya Ülken'in Kişiliği ve Düşünce Dünyası” başlıklı makalesinin ilk sayfası.

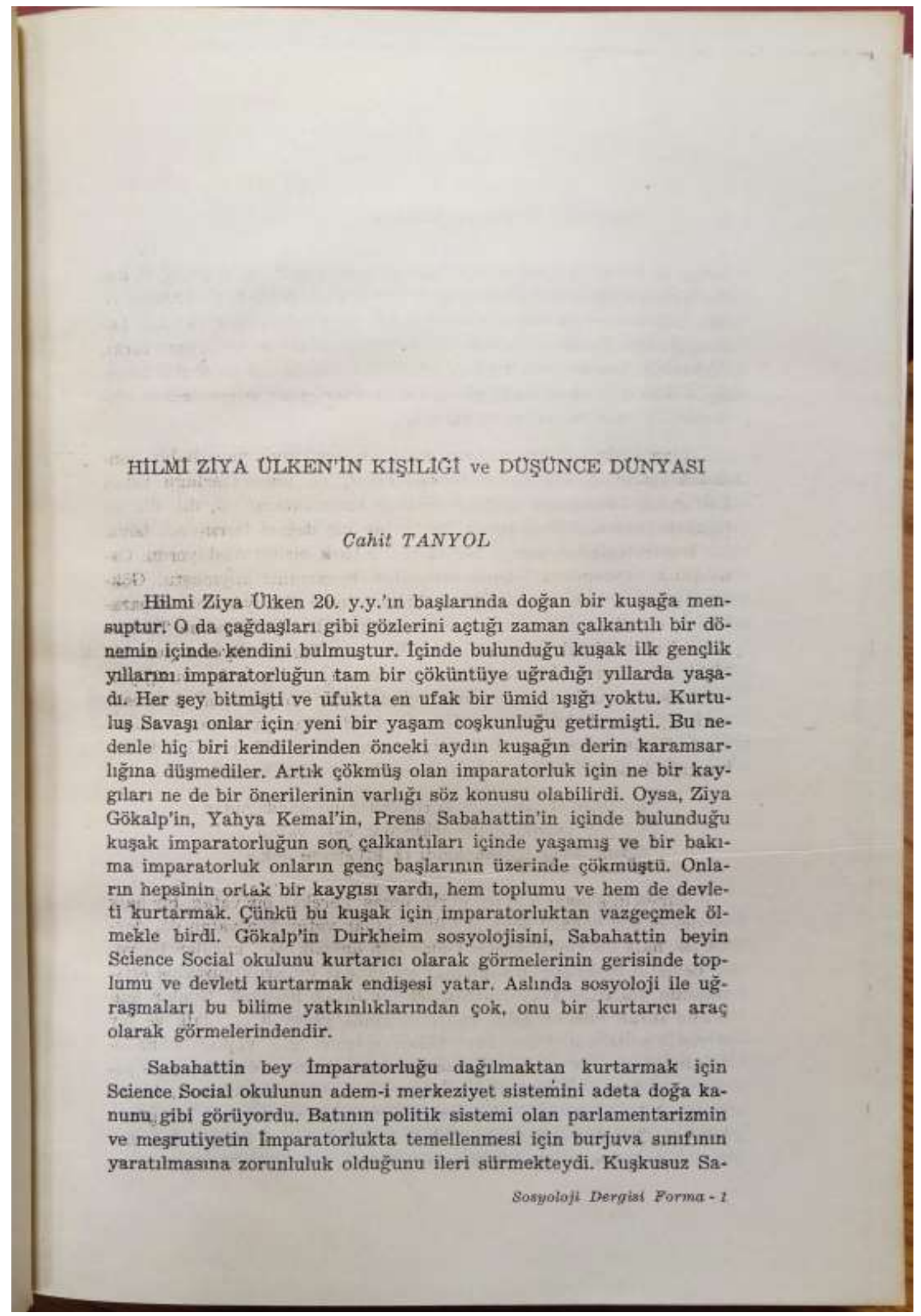


Ek 8: Prof. Dr. Cahit Tanyol'un “Atatürk Devrimleri ve Hoca Kadri Efendi” başlıklı makalesinin ilk sayfasi.

\author{
ATATURK DEVRIMLERI Ve HOCA KADRI EFENDI.
}

\title{
Cahit TANYOL
}

Atatïrk'ün yapmıs olduğu devrimlerin hemen hemen tıpkisın 1910 yillarmda savunan bir kitap var elimizde: Adt \&Sarayths, yazarı Mehmet Kadri Nàsih, yazlip yaymlandiğ1 yer Paris.

Atatürk'ün bu kitabi okudnğuna, gördüğüne veya Hoca Kadri Efendi ile tanısp tanısmadığına dair higbir belge yok. Kendisinin ozel kitaplığındaki kataloglarda da bu isme rastlamadik.

A ङ̧aḡıda *Sarayihs kitabından ve $1900-1910$ arasında Paris'te bulunanlarm anılarından edindiğim bilgileri bulacaksını. Bïtïn araștırmalarimn rağmen, ne Türkiye'de ve ne de Paris'te Hocs Kadri Efendi'nin 1910 ile 1918 yilları arasındaki hayatı hakikunda bilgi edinmek mümkïn oldu. Yahya Kemal'den ve Satvat Liitfii Tozan'dan dinlediğime göre her gün Paris'te Callé Soufflet'de oturur ve etrafinda Ali Kemal'den ģaí Esref'e, Doktor Nazım'dan Bahattin Şakir'e kadar ne kadar sürgün jön Türk varsa toplanırmig. Paris'e gelip te Café Soufflet'de Hoca Kadri efendinin çevresinde onun zehirli eleştirilerine tanik olmayan pek az insan bulunurmus. Arada sirađa Sorbonne Universitesine gider, devrin otoritelerinin felsefe, sosyoloji ve politika lizerindeki derslerini dinler ve sonra Café Soufflet'de bunlara ait ilginç eleștirilerde bulunurmus.

Yaradihs bakımından ödün vermeyen tam bir devrimci, bu nedenle komitecilikle devleti ele geçirmek, fursatlardan çkar sağlamak isteyenlerin acımasız dlişmam. A hmet Rıza, Bahattin Şakir, Doktor Nazım gibi ittihatẹllara daha o zaman karşı çkar ve Doktor Nazım'ı görince tatlı bir boşnak sivesiyle sBu Nazum yok mu onun içinde yilz tane Abdilhamit oturur, Allah bu memleketi bu haydut- 
Ek 9: Prof. Dr. Tayyib Gökbilgin'in “Macaristan'daki Türk İdaresi ile İlgili Bazı Kaynaklar” başlıklı makalesinin ilk sayfası.

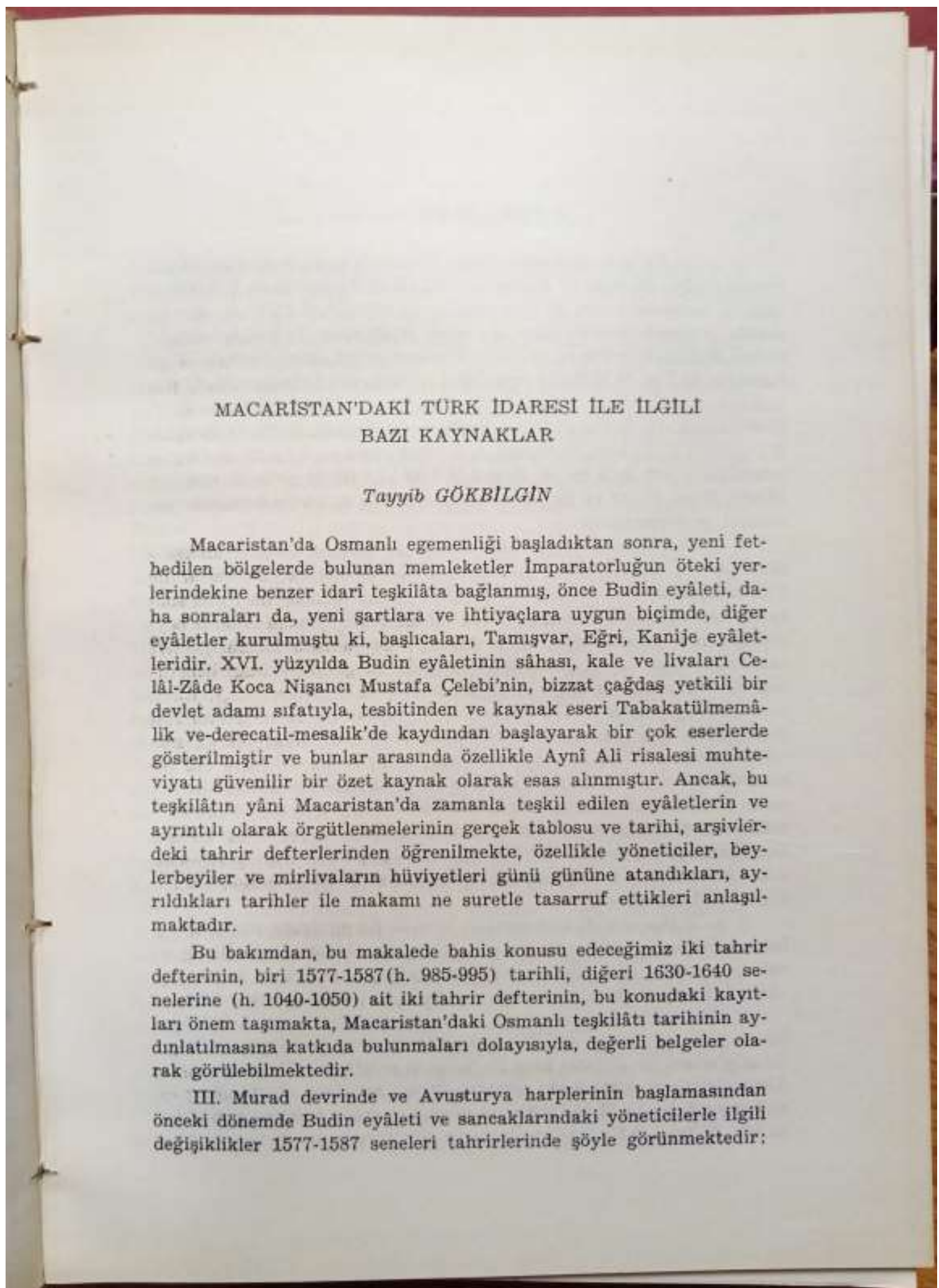


Ek 10: Prof. Dr. İbrahim Yasa'nın “Tradition of Mutual Aid in Turkish Village” başlıklı makalesinin ilk sayfasi.

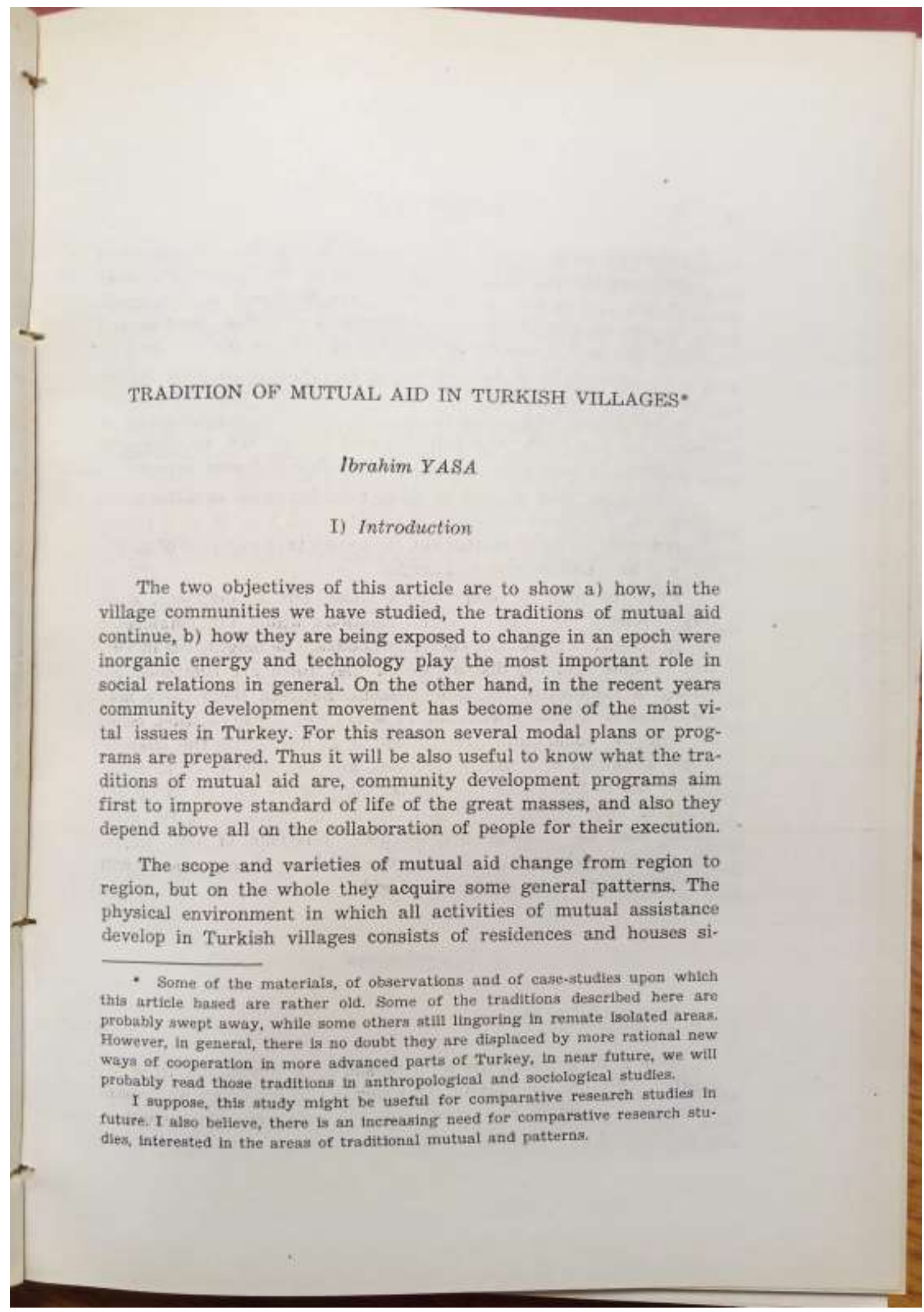


Ek 11: Pertev Naili Boratav'ın "Mudurnu Türküleri” başlıklı makalesinin ilk sayfası.

\author{
MUDURNU TURKULLERI
}

Pertev Naili BORATAV

1926-1927 ders yul. Istanbul Lisesi'nin son sunuf edebiyat bölüminde okuyorum. Sosyoloji ögrretmenimiz Hilmi Ziya, derslerinde, sirasi düstiikçe bize XIX uncu yilzyil Avrupa ullkelerinde ulusal kültïr hareketlerinden söz açıor; oralarda halkın sözllı edebiyat gelenekleri üzerinde araștırmalara aydınlarm neden önem verdiklerini, bu alanda neler yaptıklarını anlatıyor; bu arada Finlilerin ulusal destanlarının dagını parçaların bir araya getirme yolunda bir ömïr harcamis ve sonunda Kalevala'yı diriltmiş olan Lönnrot'un çahşmaları ijzerinde uzun uzun duruyor. Hocam, halk edebiyatı sorunları üzerine anlattiklarma benim özel bir ilgi gösterdiğimin farkına varmış olacak ki, onunla başka vesilelerle konuşmalarımızda, sira diiştiikçe, bu konulara dönityor...

Ders yil sonunda Hocaya Universitenin Edebiyat Bölümünde okuma kararımı aęyorum. O yillarda babam Mudurnu'da kaymakamdir; ben her yil tatillerimi geçirmeğe, Bolu ilinin 800 hanelik bu küçuk kasabasana gidiyorum. Bunu ögrenen Hocam bana o tatil için bir araģtırma programı çiziyor : Mudurnu yerlileri ag̈zından tïrlii halk edebiyatı metinleri derleyeceğim. $O$ tarihte henliz lâtín alfabesi kabul edilmiş değildir; derlemelerimin, dil özelliklerini yitirmeden yazılabilmesi için Hocam, bir «çevir-yazı kalavuzu veriyor elime. Iște benim, halk edebiyatı derlemelerimde ve araştırmalarımda ilk denernelerim böyle başlamıstır.

Hilmi Ziya Hocamm anısina armağan edilecek kitaba, eski bir ögrencisinin en yerinde katkısı, onun teşvikiyle ve rehberliğiyle giriştiği ilk derlemelerinin yayımlanması olur diye düşündüm.

Aradan elli iki yrl gibi uzun bir süre geçtigit halde, bu metinleri 
Ek 12: Prof. Dr. Cahit Tanyol'un "Le fondement social du droit de l'Islam" başlıklı konuşmasının ilk sayfasi.

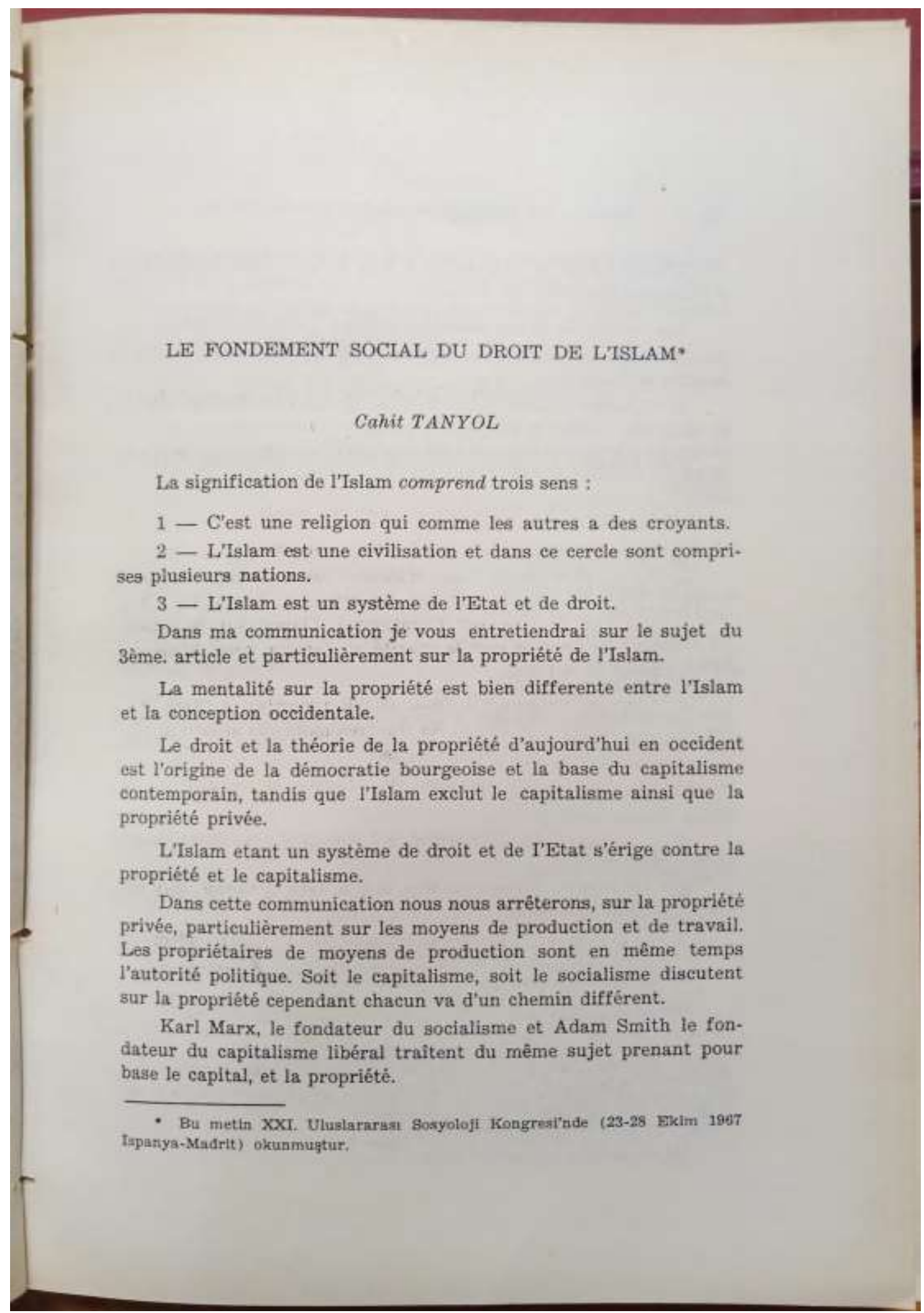


Ek 13: Dr. Ümit Meriç’in “İslâm Sosyolojisi İçin Bir Bibliyografya Denemesi” başlıklı makalesinin ilk sayfası.

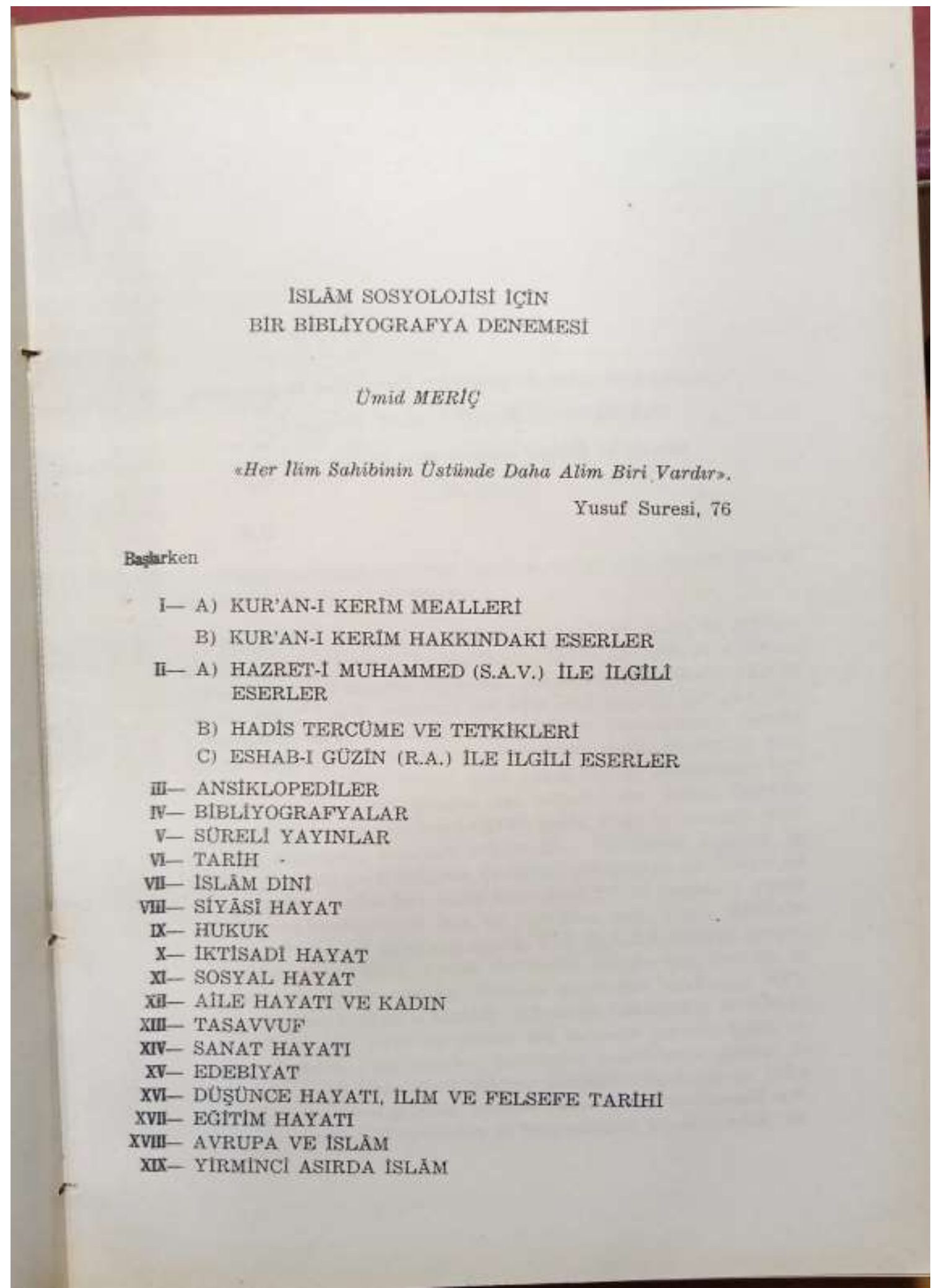


Ek 14: Dr. Ümit Meriç'in makalesinde Muzaffer Ozak'a yaptığı ithaf.

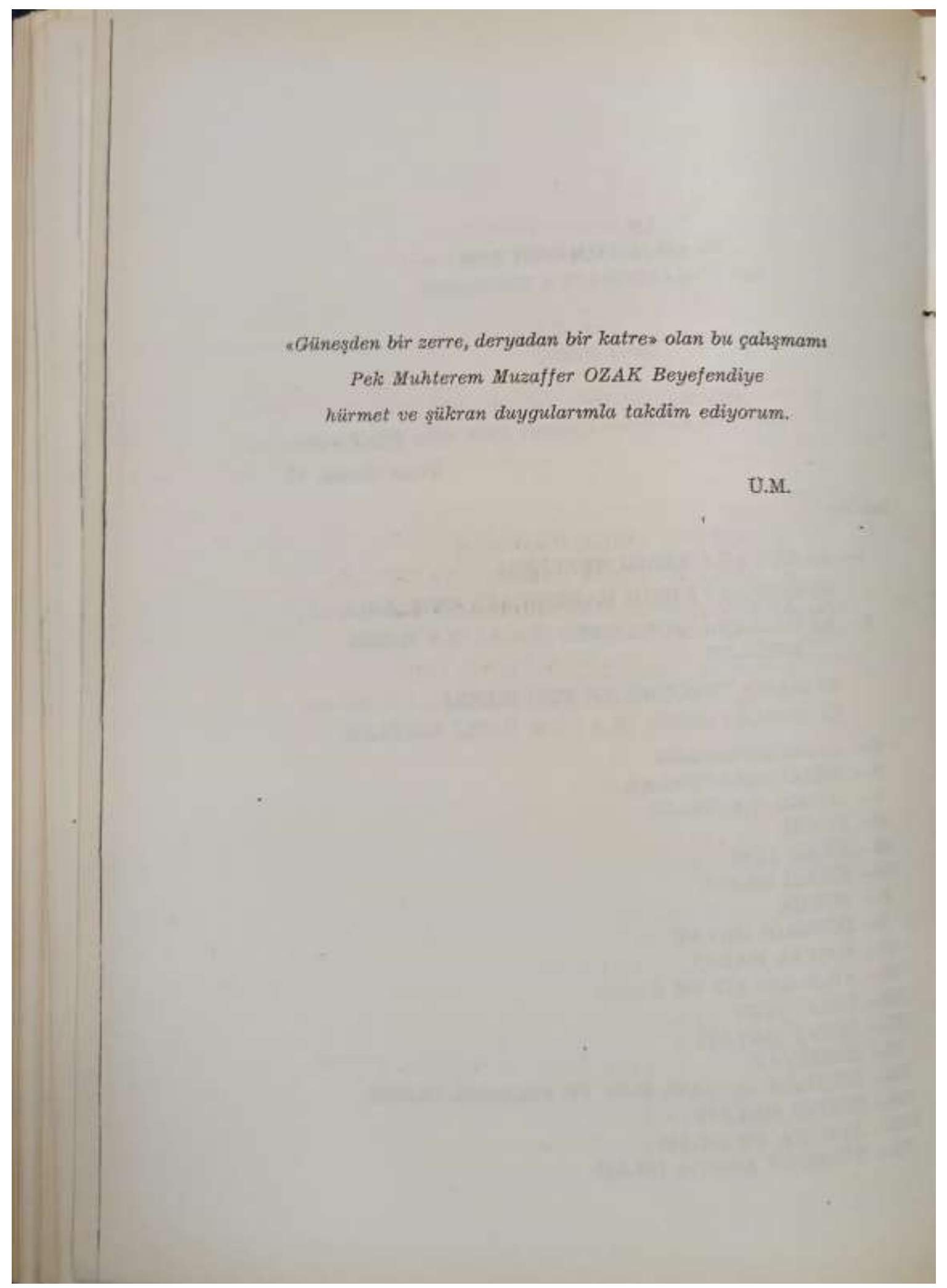


Ek 15: Dr. Mahmut Arslan'ın “Step İmparatorlularında Ekonomik ve Sosyal Yapı” başlıklı makalesinin ilk sayfasi.

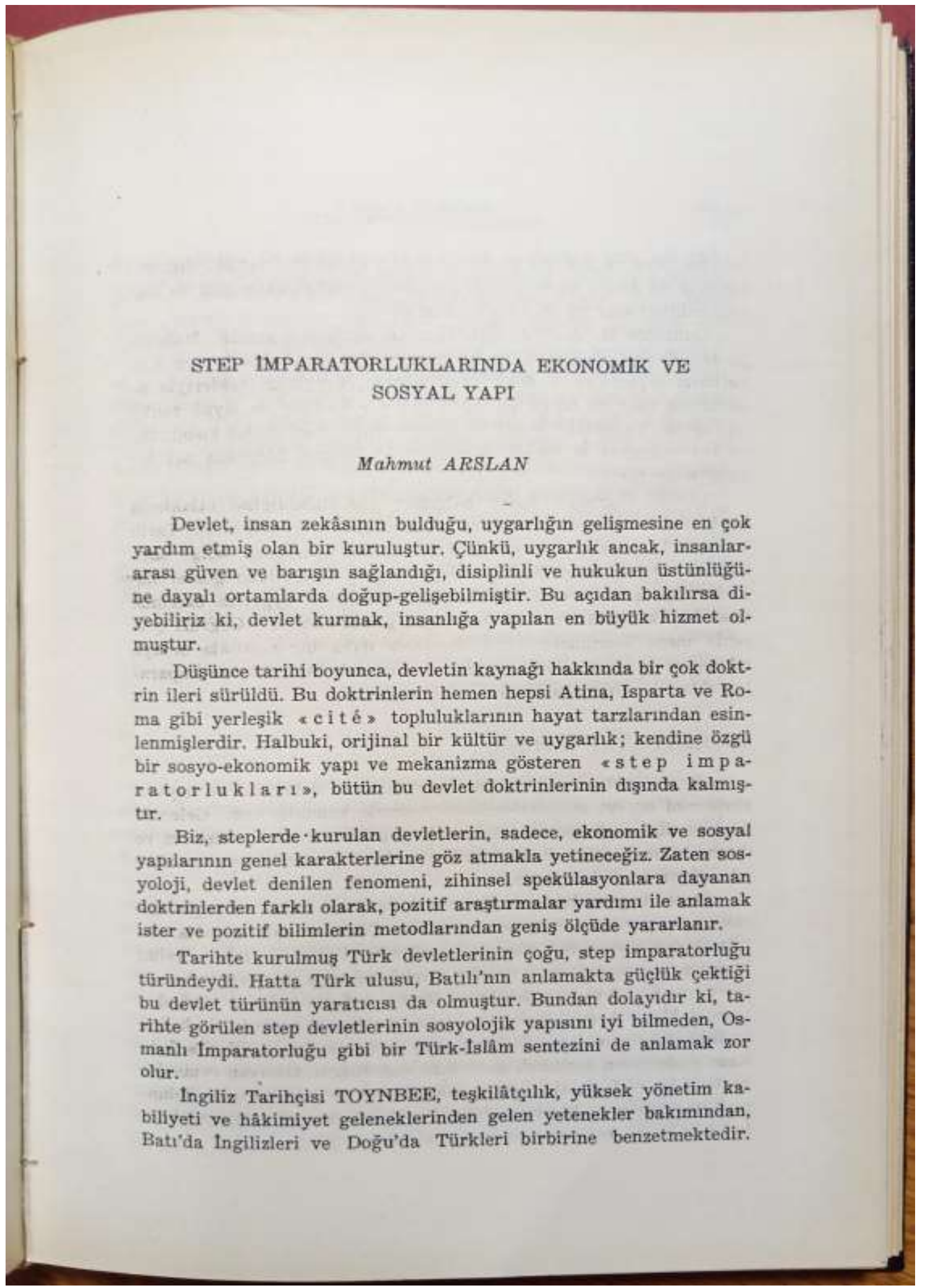


Ek 16: Dr. Fügen Berkay'ın “Genel Boyutları İçinde Yurtdışına İşgücü Göçü Olayı ve Bazı Sorunlar” başlıklı makalesinin ilk sayfası.

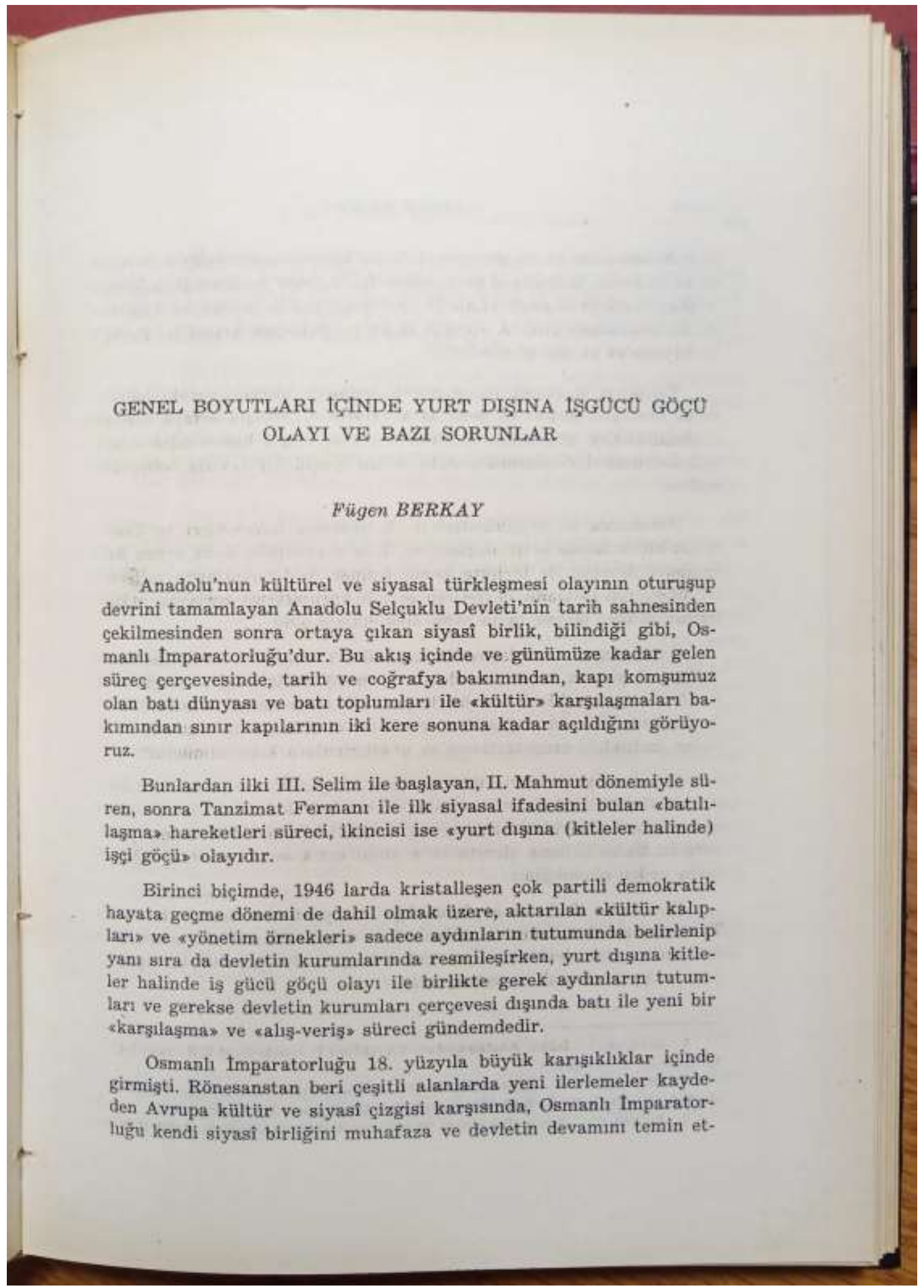


Ek 17: Doç. Dr. Baykan Sezer’in “Yurdumuzda Sosyoloji” başlıklı ders notlarının ilk sayfası.

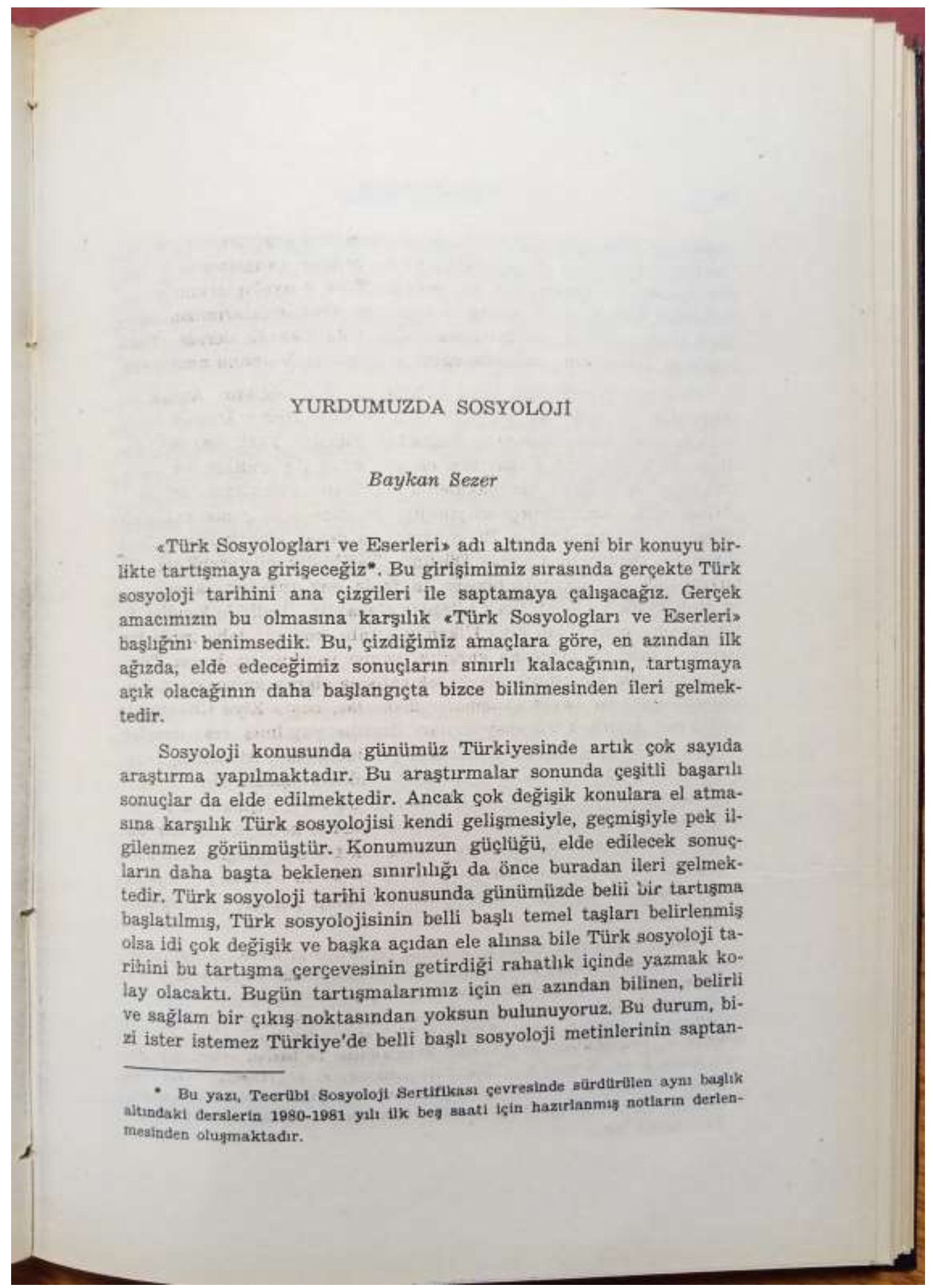


Ek 18: Bedri Mermut[lu]'nun hazırladığg Ziya Gökalp'in “İlm-i İçtimâ' Dersleri” başlıklı ders notlarından oluşan yazının ilk sayfası.

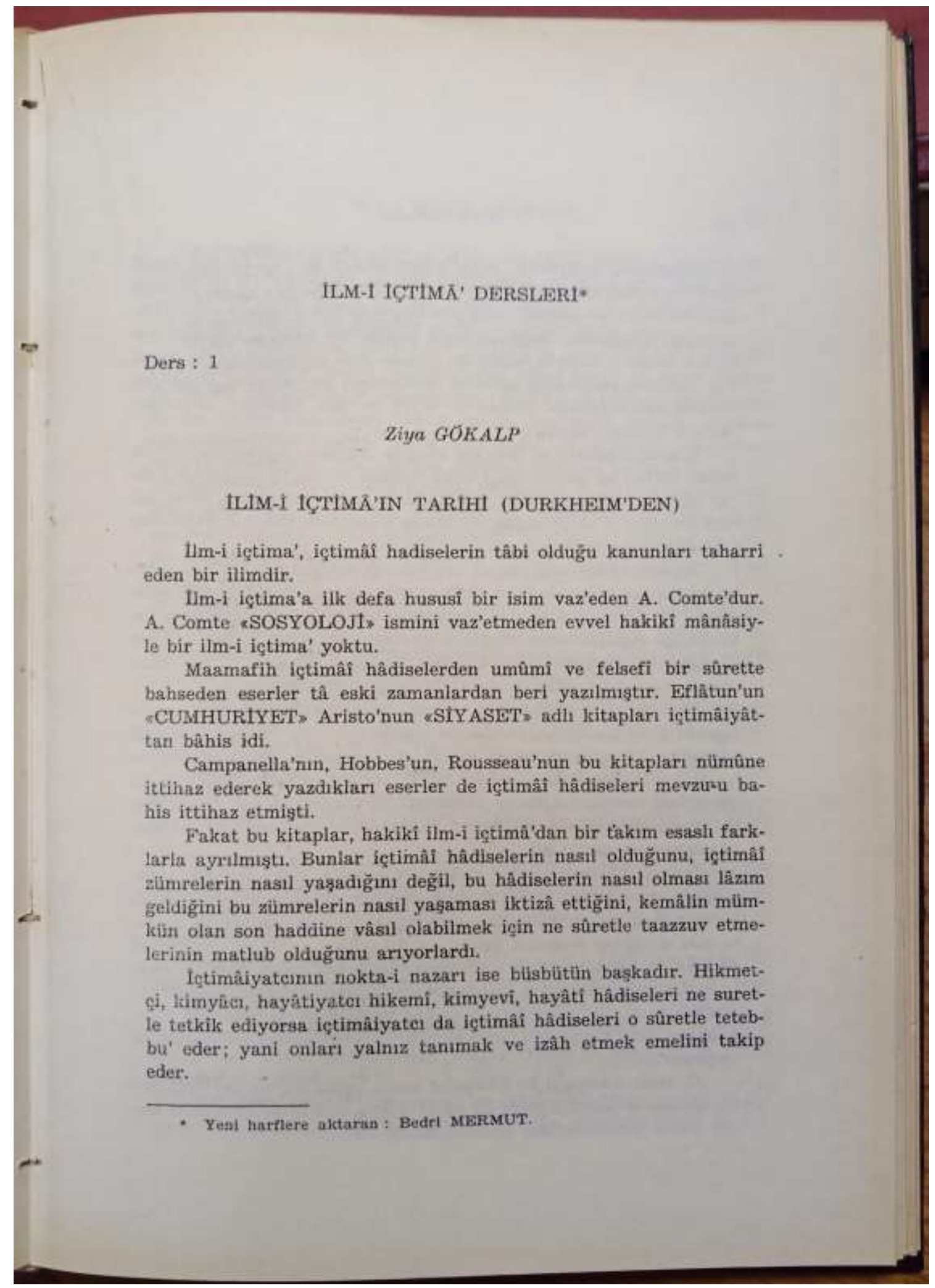


Ek 19: Dr. Mehmet Yalvaç’ın “İstanbul Üniversitesi Edebiyat Fakültesinde Sosyoloji Eğitiminin Tarihçesi (1912-1982)" başlıklı makalesinin ilk sayfası.

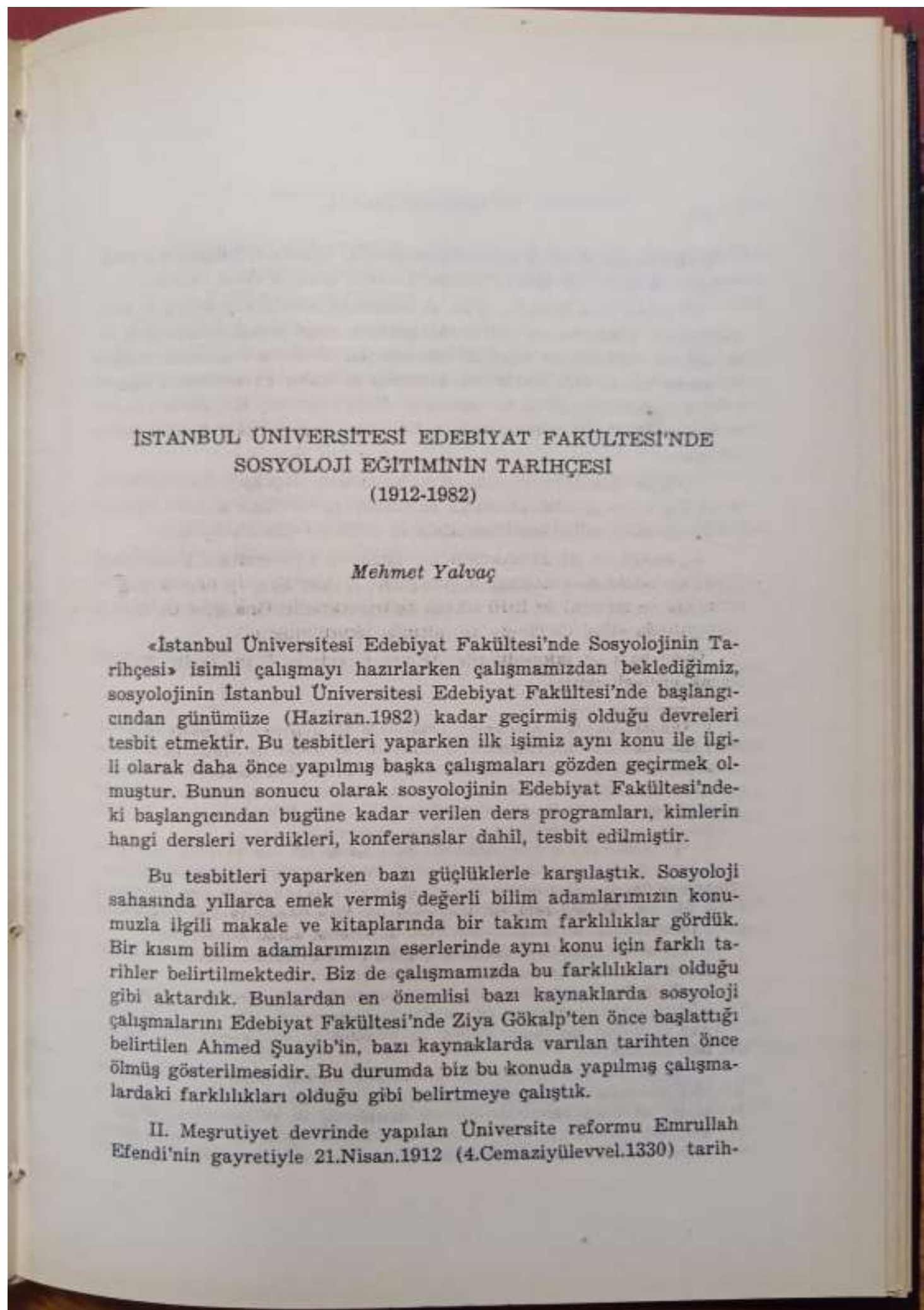


Ek 20: Dr. Tuğrul Tanyol'un “Toplumsal-Kültürel Yapı ve Kişilik Kuramlarına Genel Bir Yaklaşım” başlıklı makalesinin ilk sayfası.

TOPLUMSAL-KULTUREL YAPI VE KIŞILIK KURAMLARINA GENEL BIR YAKLASSIM

\section{Tuğrul TANYOL}

Sosyolojinin flgi alanı toplumdur. Bununla birlikte bu, bu bilim dalınin tek tek insanlarla ilgilenmediği anlanını taşımaz. Toplum soyut bir kavramdar, oysa insan somut bir gerçektir. Toplumu elde edeblimek için önce onu oluşturan insanları tammak gerekir. Ne var ki insan hiç bir zaman toplumdan yalitılmı bir biçimde bulmak mümkün değildir. Toplumu anlayabtlmek için nasıl insanlara gereksinmemiz varsa insanı anlayabilmek için de, onun içinde yaşadığ toplumu anlamamiz, yani insan ve toplumu birlikte ele almamı gerekir.

Ama insan nedir? Insanın doğasını ya da kiş̧iliğini, davranığarin belirleyen etmeler nelerdir? Sosyal bilimlerin, bir bilim olarak ortaya cıkmasından önce bu konu felsefenin önemli sorunlarindan biriydi. Felsefe insanla ilgili sorunlarına son vermemis olmakla birlikte bu soru bïyïk ölçudde sosyal bilimlerin tartışma alanıa aktarılmigtur. Bu yazı insan ve toplum arasındaki iliģkilerin sosyal bilimlerde nasıl ele alınđ̊ğına bir göz atmayı ve bu konudaki bashea kuramları kısaca incelemeyi amaclamaktadır. Sosyal bilimlerdeki bu tartıgmaya girmeden ónce, geçmiște insanın doğası tizerine söylenenleri belirtmek gerekir. 
Ek 21: Dr. Ümit Meriç’in çevirdiği Prof. Dr. Kenneth Denbigh'in “ỉlmi Metod: Düzen mi, Hürriyet mi?" başlıklı yazısının ilk sayfası.

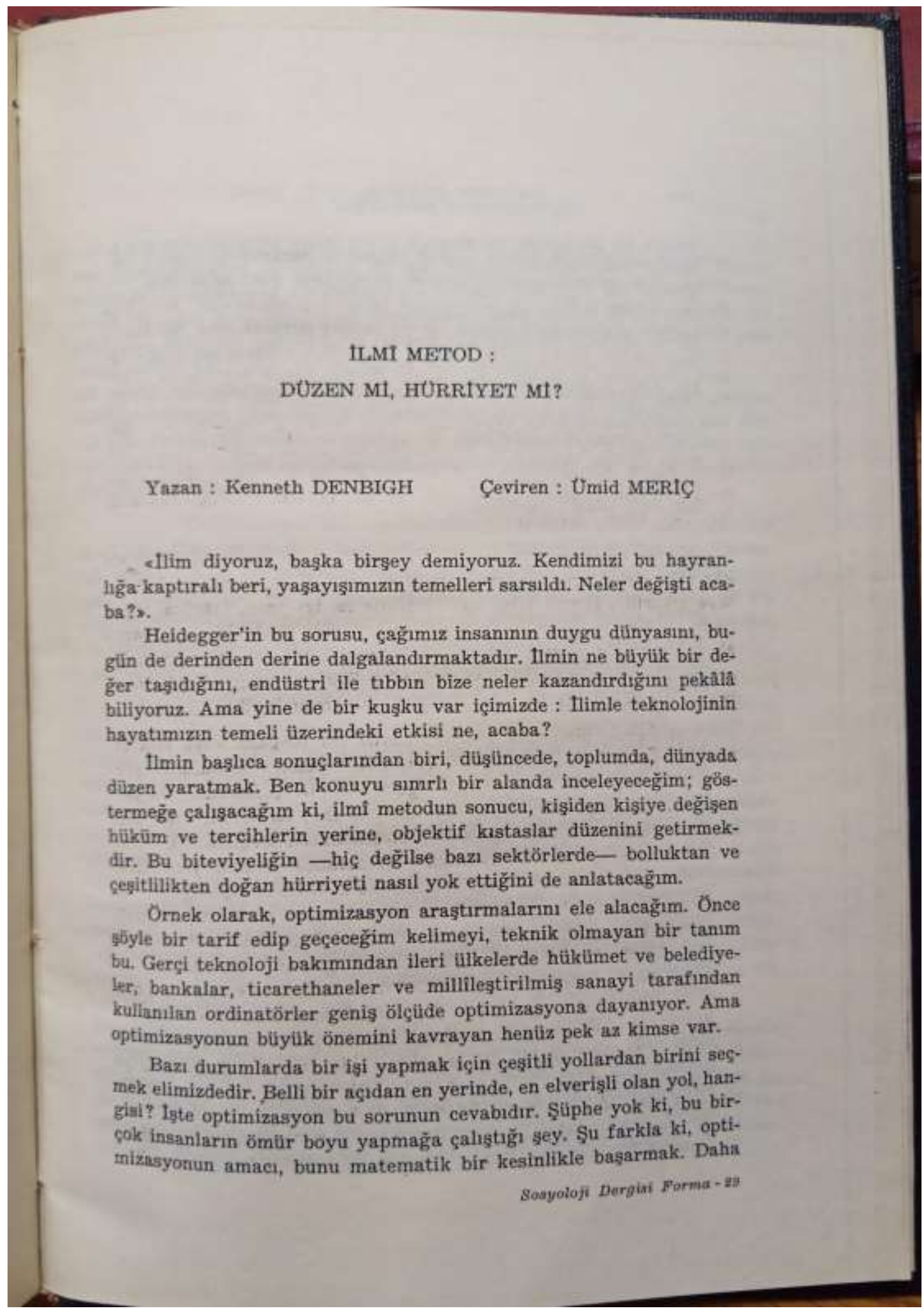


Ek 22: Dr. Adil Çağlar'ın 'Kürsümüze Yapılan Doktora Tezleri” başlıklı bibliyografik yazısının ilk sayfasi.

\author{
KURSUMUZDE YAPILAN DOKTORA TEZLERT
}

Haz. : Adil CQAGLAR

Ziya Somar : Son Asır Türk Tefekkür Tarihi ve Mehmet tzzet.

Kâmuran Birand : Aydınlanma Devri ve Türk Dügüncesi Uzerine Baza Tesirleri.

Cahit Tanyol : Ahlakta Haz ve Elemin Yeri.

Hikmet Gökalp : Pareto Sosyolojisinin Metodu.

Cavit Orhan Tütengil : Montesquieu'nun Siyasî ve Iktisadi Fikirleri.

Necip Oğuz Arı : Bulgaristanlı Göçmenlerin Intibakı.

Ayda Yörükkan : René Maunier ve Sosyal Morfoloji.

Muzaffer Sencer: Sosyal Sınıf Kriterleri Uzerine Eleştirmeli Bir Deneme.

Hasan Sabuncu Rizapur : Iran'da Dinin Sosyal Etkisi.

Baykan Sezer : Doğuda Yerlegik ve Göģebe Toplumların Sosyolojik Ozellikleri Uzerine Bir Deneme.

Hasan Küçïk : Tarikatlarm Türk Toplumundaki Sosyal Fonksiyonlari.

Behruz Parsi : Iran'da Eğitim ve Oğretimin Toplum Uzerine Olan Etkisi.

Ahed Zerforugan : Iran'da Toprak Mülkiyeti,

N. Purefkarl : Iran Çingenelerinin Sosyal Yapısı Uzerine Bir Arastirma.

Perviz Ilmi : Iran'da Verginin Sosyal ve Ekonomik Hayatta Etkisi.

Ayse Fügen Berkay : Yunus Emre'nin Türk Toplumundaki Yeri.

Mirzanga Pouramouz : Tebriz Cevresindeki Köylerde Orf ve Adetler.

Ahad Behdjat : Megrutiyet Öncesi Iran'da Sinat Ekonominin Gelismesi.

Umid Meriç : Cevdet Paşa'nın Cemiyet ve Devlet Görușil. 